\title{
I. 日本鐵銅協會第十回研究部會第六回製銅部合順序
}

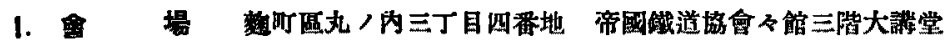

1. 時 日 昭和 9 年 4 月 2 日 (月嚯白) 午前 9 時 30 分開會
(1) 開合 の，拟

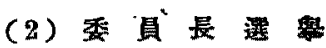

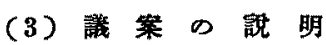
(4) 各委員提出资料の鿁昨
(5) 討
軥
(6) 閉會の换

日本践銅别會々長工學博士 河村騂 君 委員長 工學博士 吉 川 啨十 君 各工場 委員 前

同

會長 工學博士 河村騂 君

\section{II. 日本鐵䤡協會第十回研究部會委員名簿}

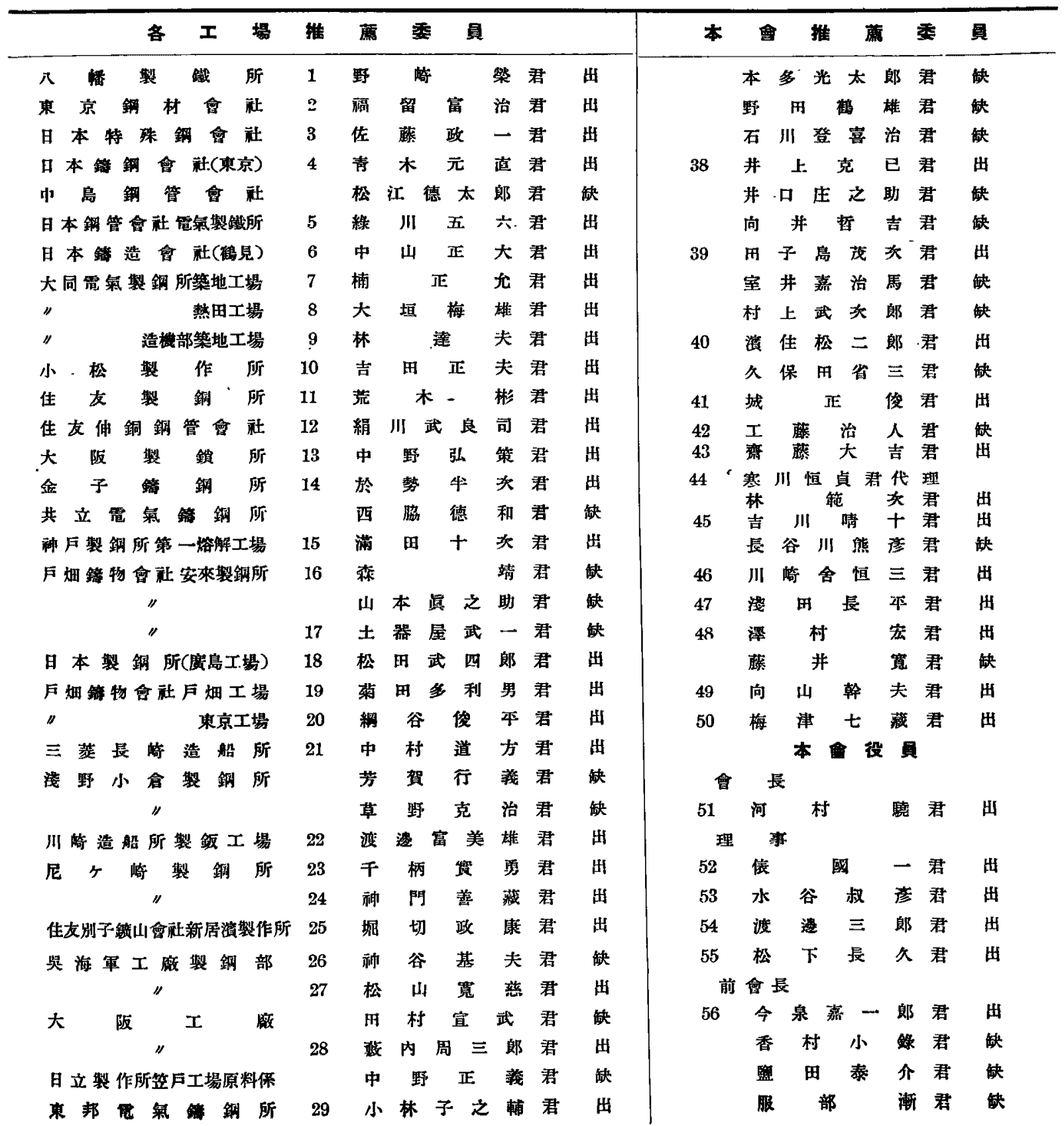




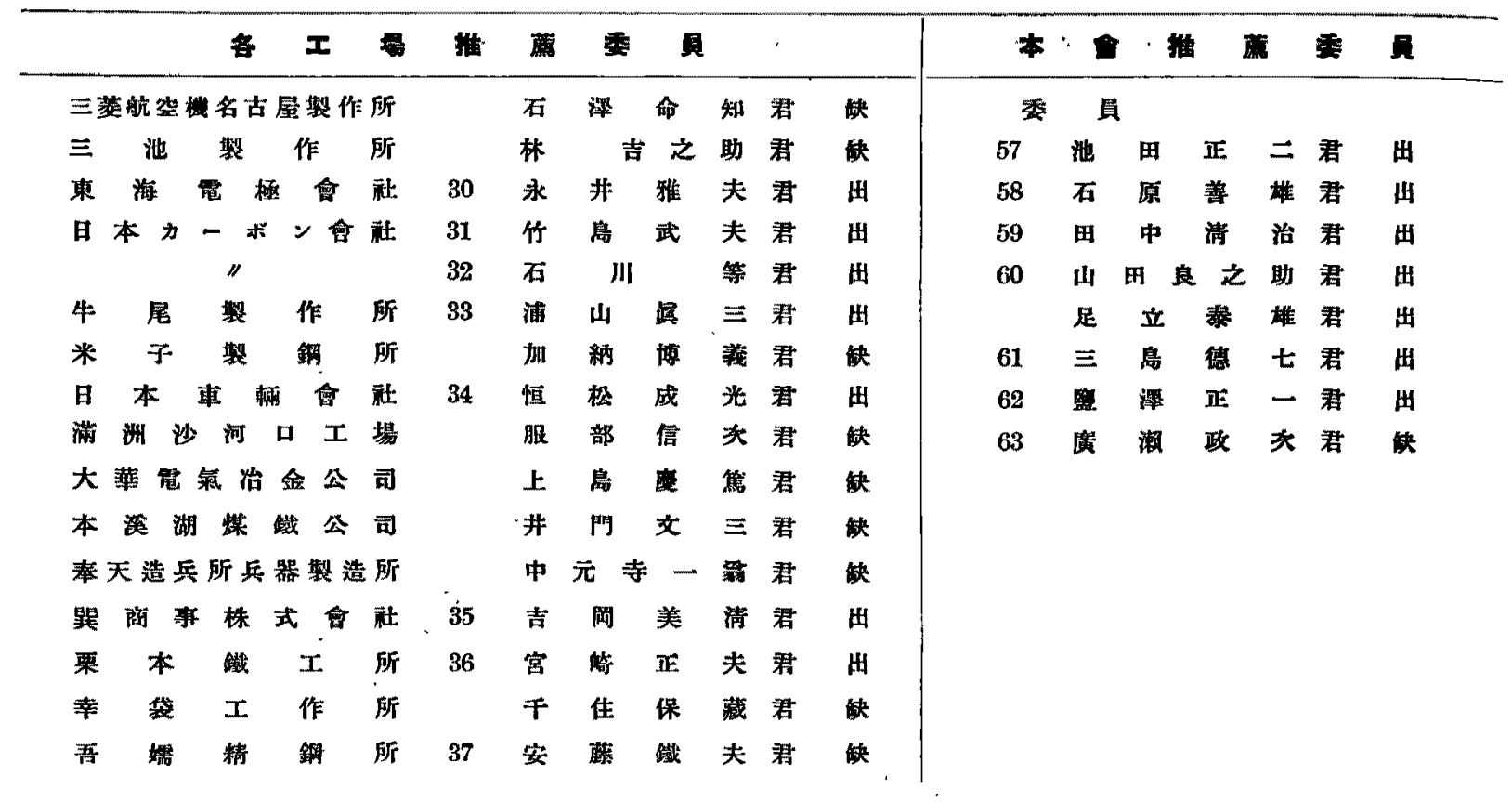

\section{III. 討 議 項目及討議希 望 㜖}

\begin{tabular}{|c|c|c|c|}
\hline 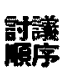 & $\begin{array}{l}\text { 湎圆 } \\
\text { 番视 }\end{array}$ & 项 目 & 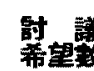 \\
\hline 1 & 16 & 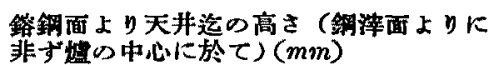 & $=$ \\
\hline 2 & 19 & 嘘床直徑（或忙長さ及幅） $(\mathrm{mm})$ & 5 \\
\hline 3 & 22 & 㢈床の厚さ (mm) & - \\
\hline 4 & 69 & 電極の材質 & 0 \\
\hline 5 & 71 & 電極相互閒の中心距襍 $(\mathrm{mm})$ & 5 \\
\hline 6 & 114 & 装入の方法 & 5 \\
\hline 7 & 133 & 電力消費量 $(k . w . h / t)$ & 9 \\
\hline 8 & 135 & 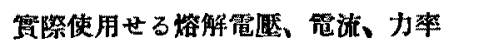 & 7 \\
\hline 9 & 136 & 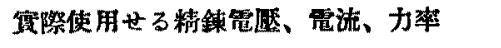 & 7 \\
\hline 10 & 140 & 電極消費量 $(\mathrm{kg} / \mathrm{t})$ & 8 \\
\hline 11 & 152 & 珪素践の珪乘\%及其の使用量 $(\mathrm{kg} / \mathrm{t})$ & 4 \\
\hline 12 & 153 & $>ル ミ=ウ ム の$ 使用法及使用量 $(\mathrm{kg} / \mathrm{t})$ & 4 \\
\hline 13 & 154 & 其の他の脱酸新使用量 $(k g / t)$ & 5 \\
\hline 14 & 156 & 脫酸检定法 & 4 \\
\hline & 14 & 㙮銅表面皘(銅涬面に非ず) $(n, m)$ & 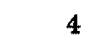 \\
\hline & & 珹代曲面の牛徑 $(\mathrm{mm})$ & \\
\hline
\end{tabular}

\begin{tabular}{|c|c|}
\hline 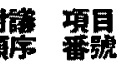 & 項 \\
\hline 23 & 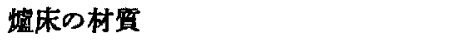 \\
\hline 24 & 螬休のバインダ-- \\
\hline 25 & 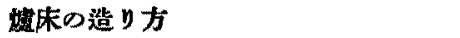 \\
\hline 32 & 側壁の厚さ $(\mathrm{mm})$ \\
\hline 41 & 天井煉瓦の厚さ $(\mathrm{mm})$ \\
\hline 74 & 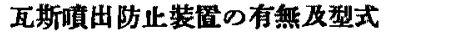 \\
\hline 94 & 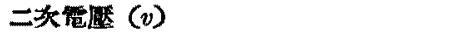 \\
\hline 121 & 送電後鎝解运の時䦎(時分) \\
\hline 129 & 䑀橉啭(\%) \\
\hline 131 & 送電より鉻解迄の琶力消費量 $(k w . h / t)$ \\
\hline 132 & 精钵に要する麗力消費量 $(k . w . h / t)$ \\
\hline 134 & 1 鉻解掌力負荷率(\%) \\
\hline 141 & 蝹琶使用间敨 \\
\hline 142 & 蜼壁使用回数 \\
\hline 143 & 蝠床使用国数 \\
\hline 以 & 下 略 \\
\hline
\end{tabular}

禁量
6
6
4
4
4
4
4
4
4
4
4
5
4
5
4
4
3




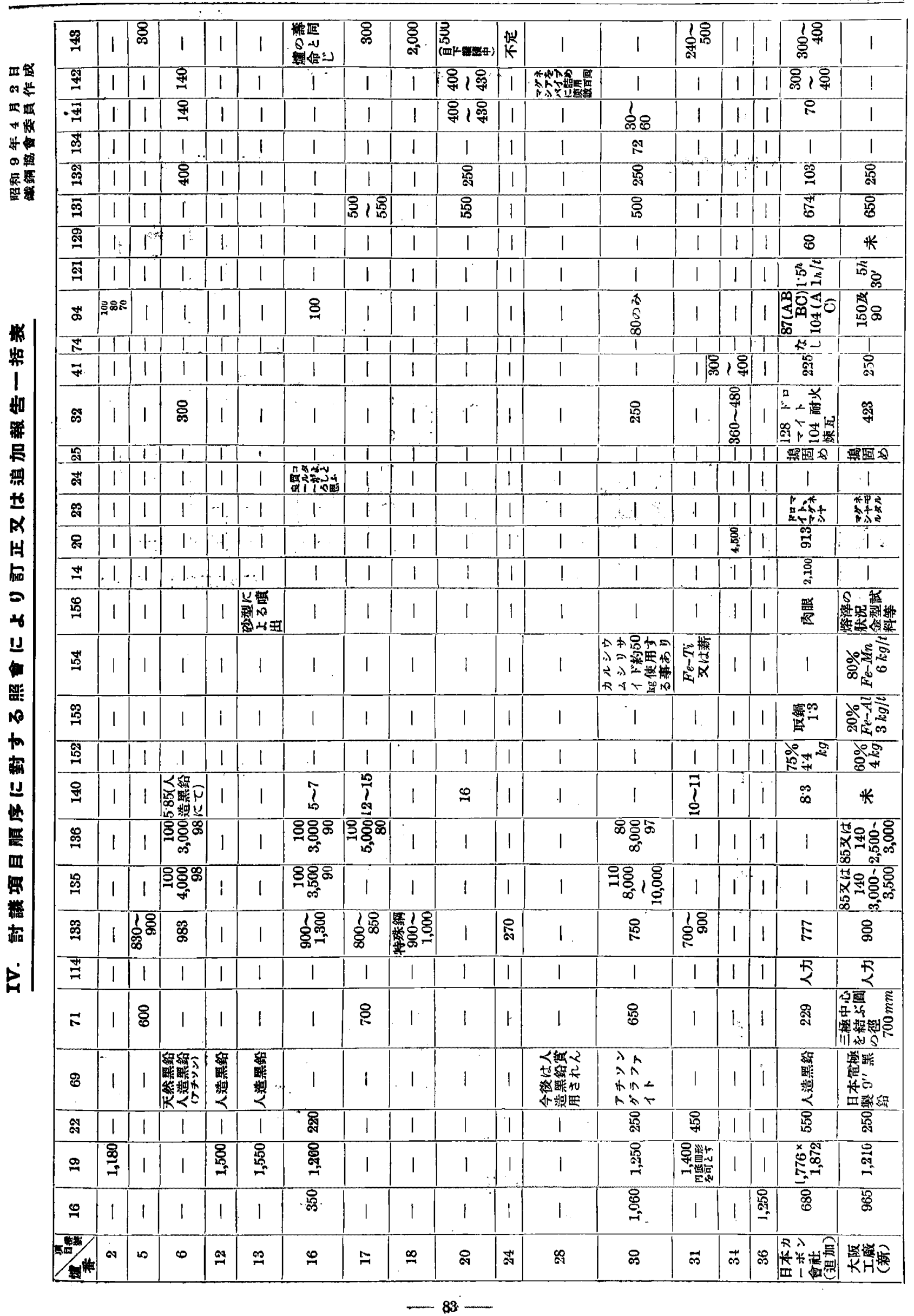


V. 萑考曲線回

熔鋼面の表面䞍（14）

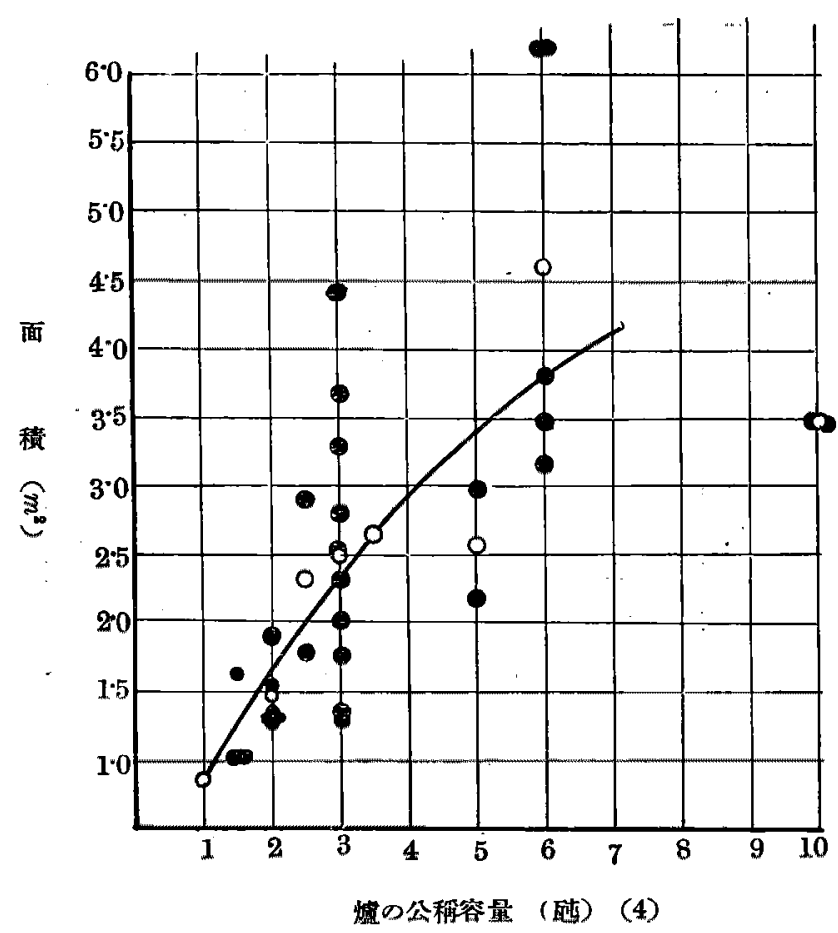

熔鋼の深さ (15)

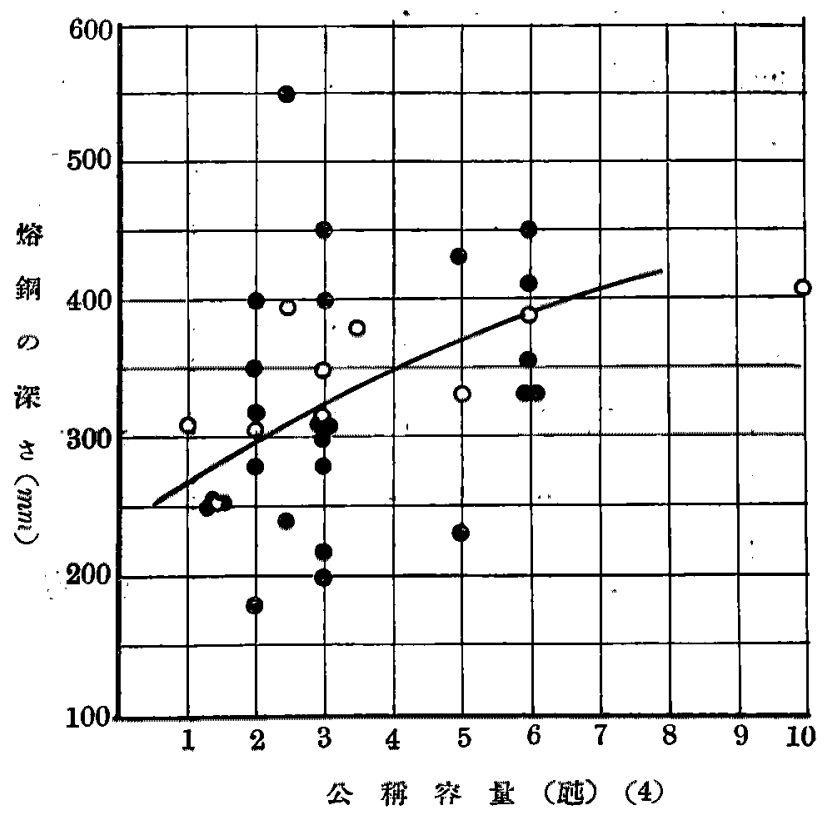

揢鎡面より天井迱の高さ（16）

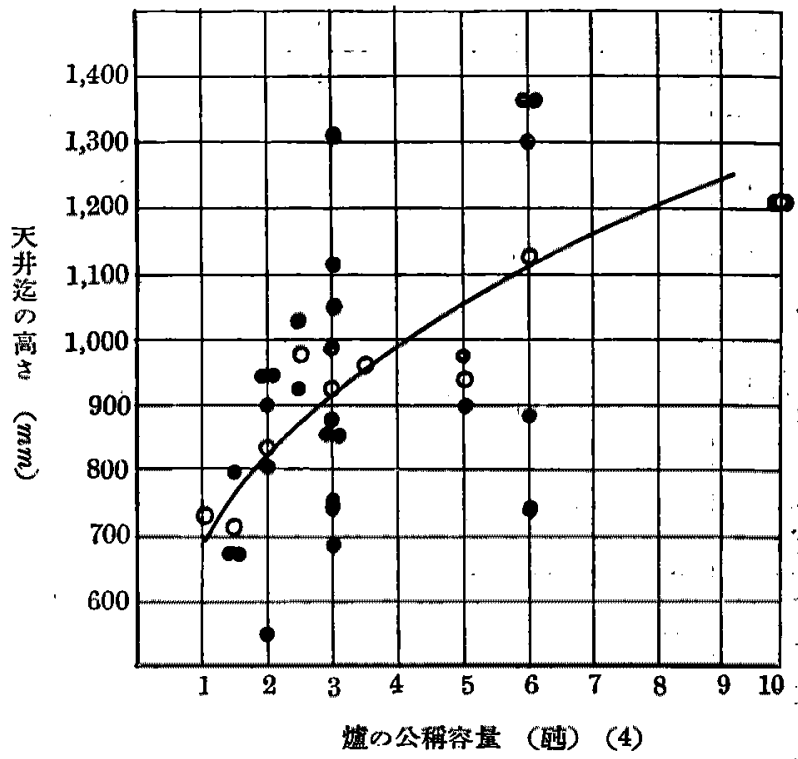

揢鋼の接解面糟 (18)

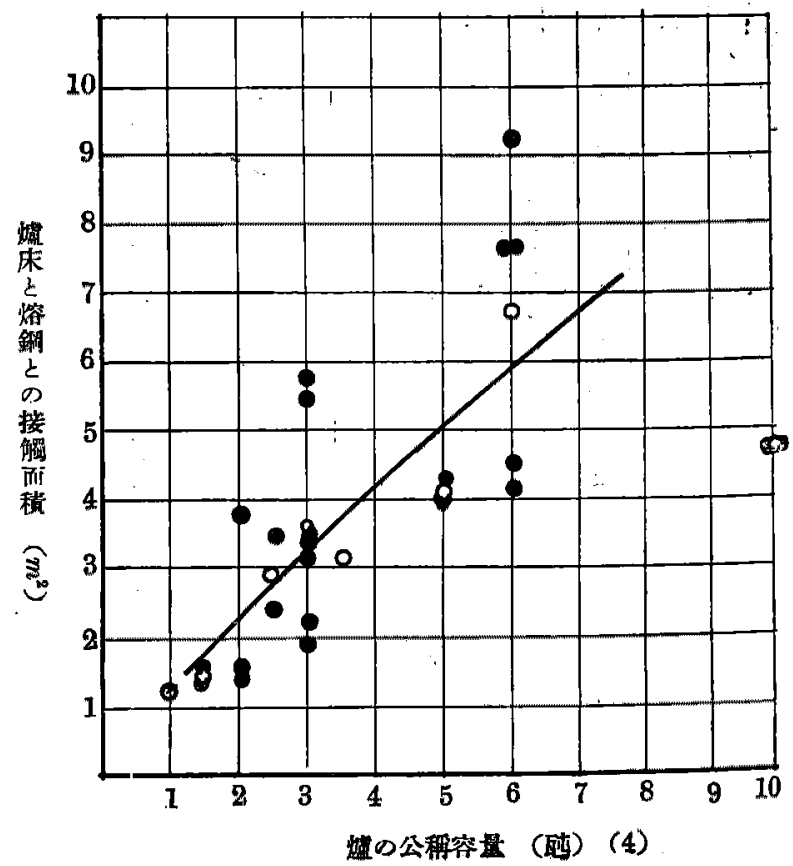


珹度宣 亚 (19)

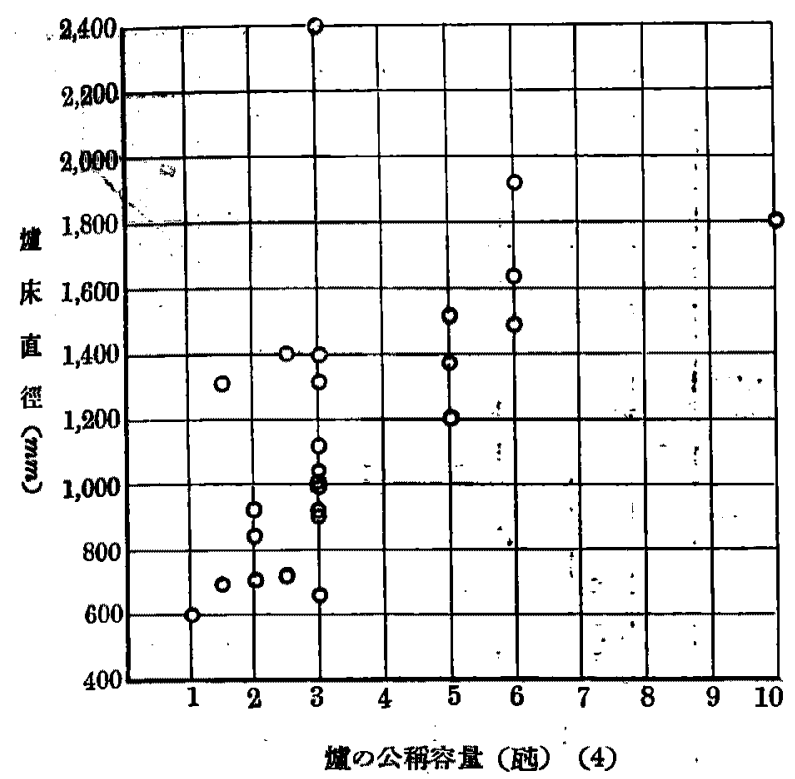

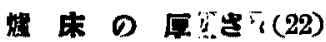

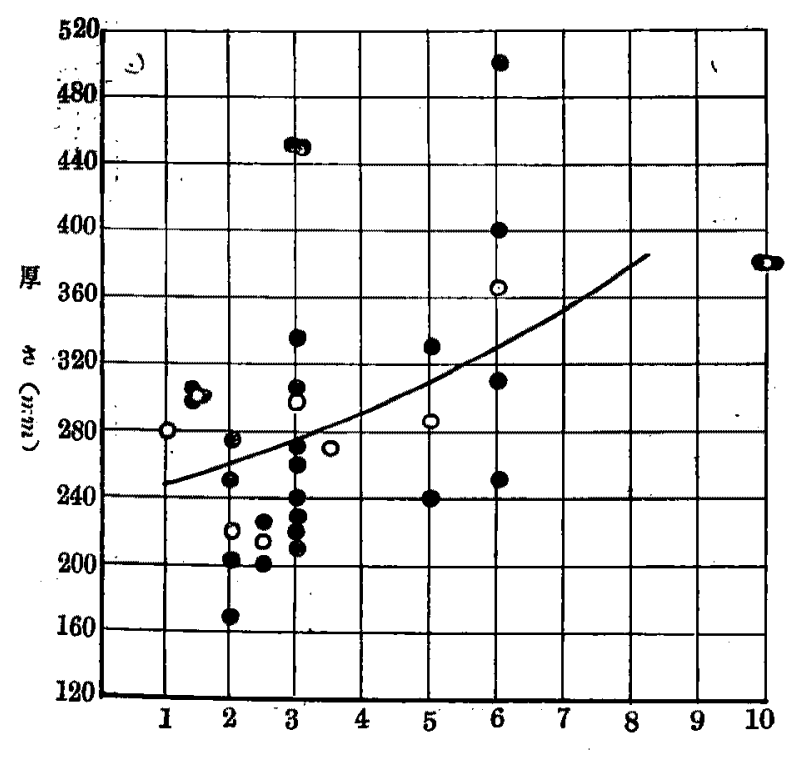

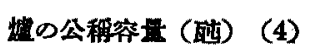

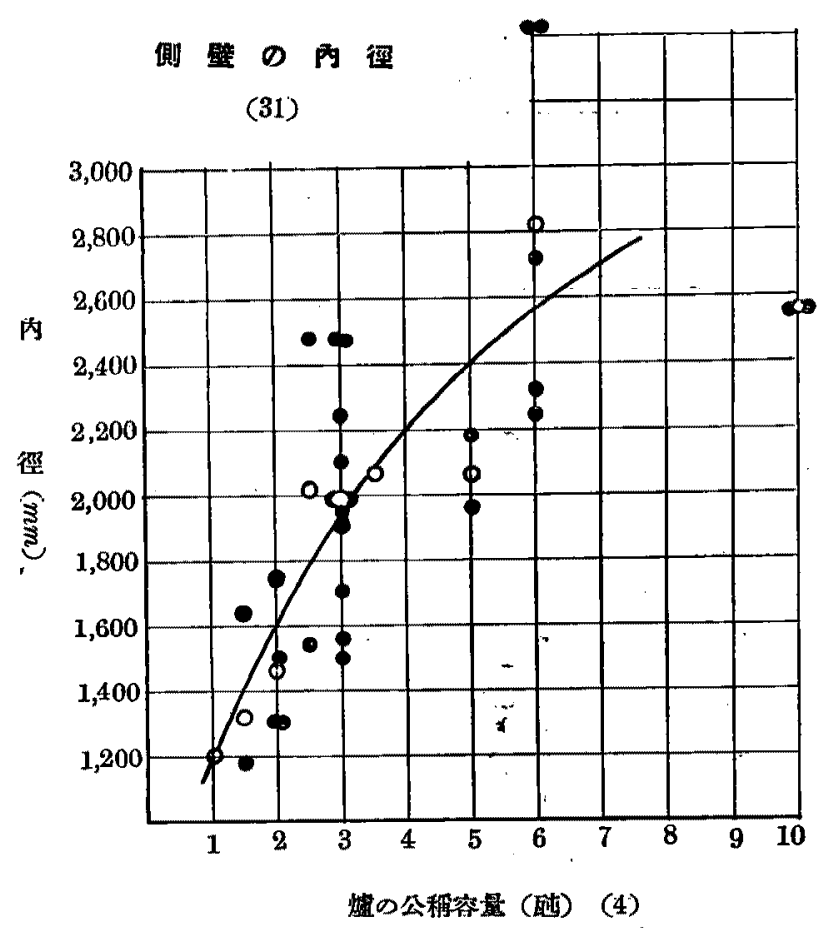

蛙

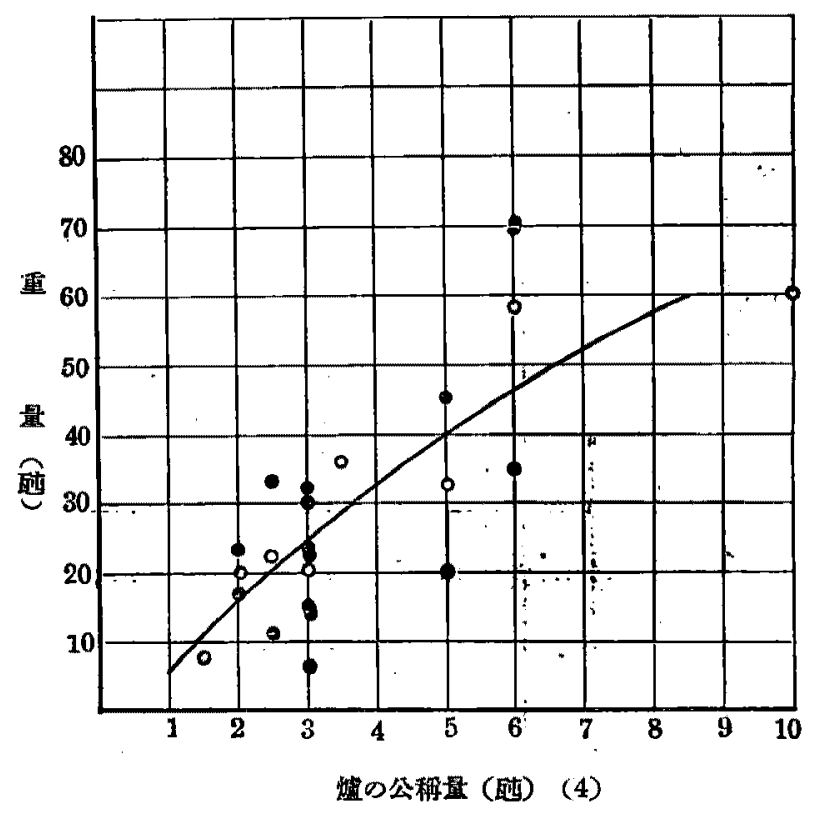


電㮌 の直 徑 (67)
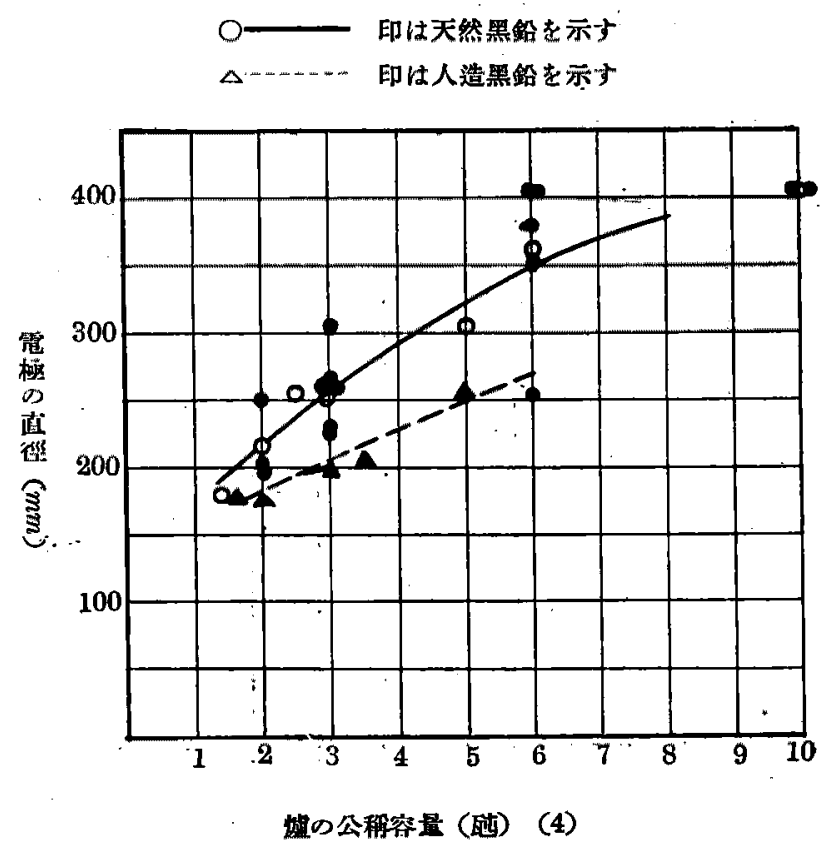

施の公程察量（鴙）（4）

緟熙器容 (92)

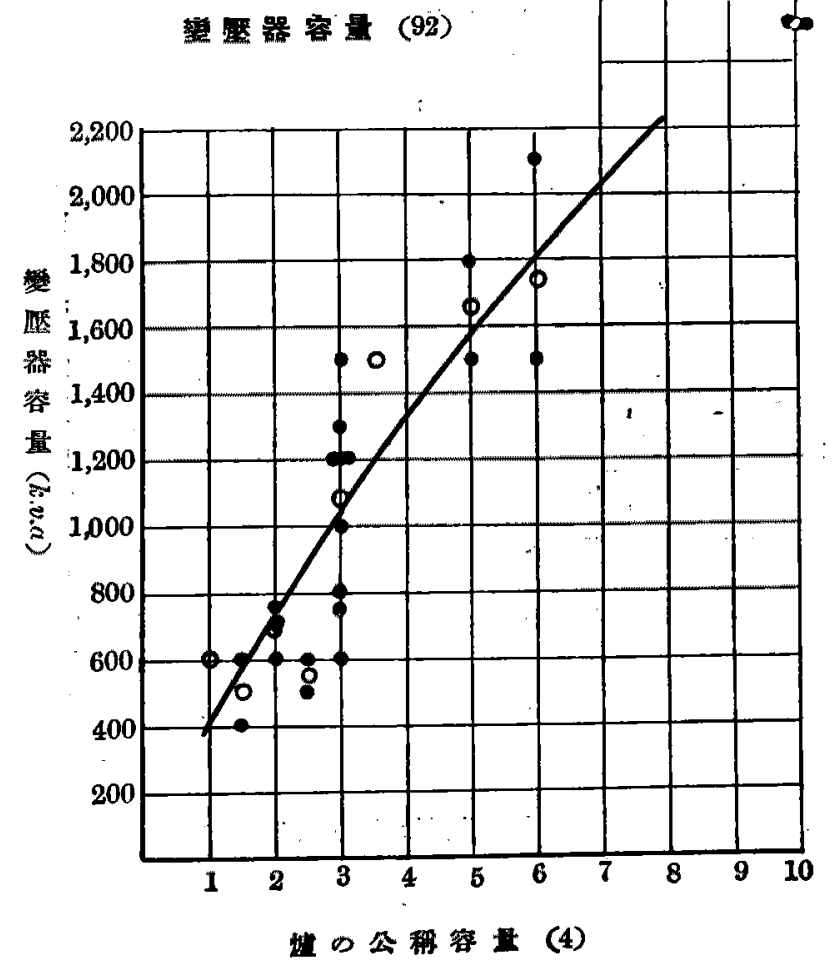

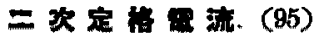

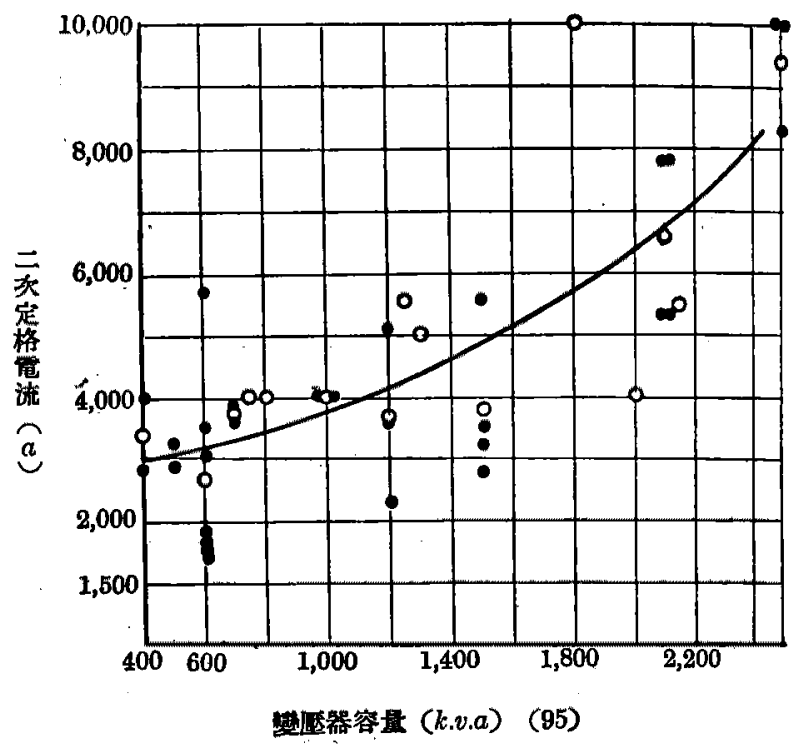

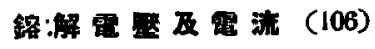

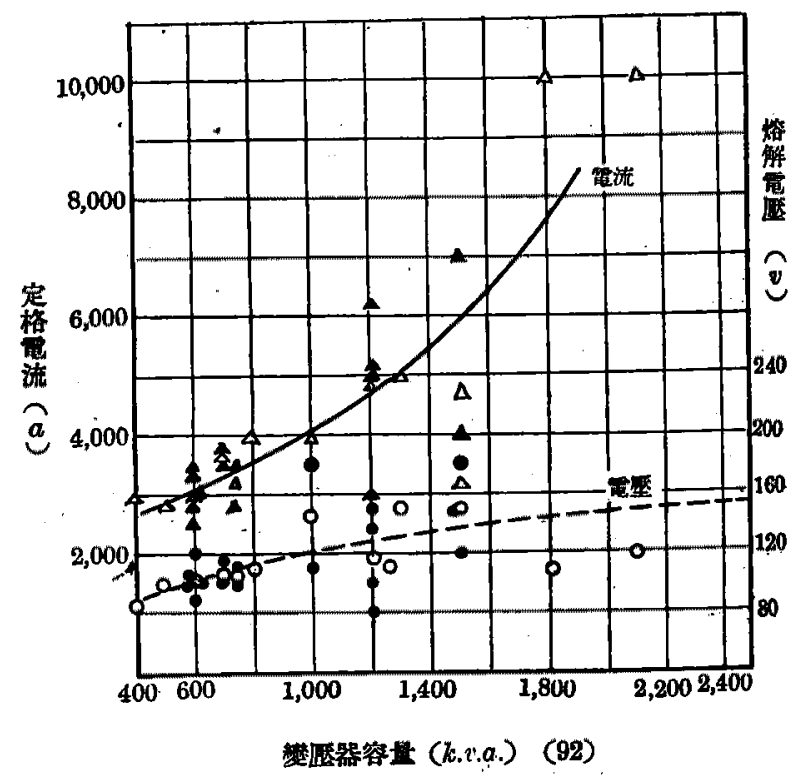



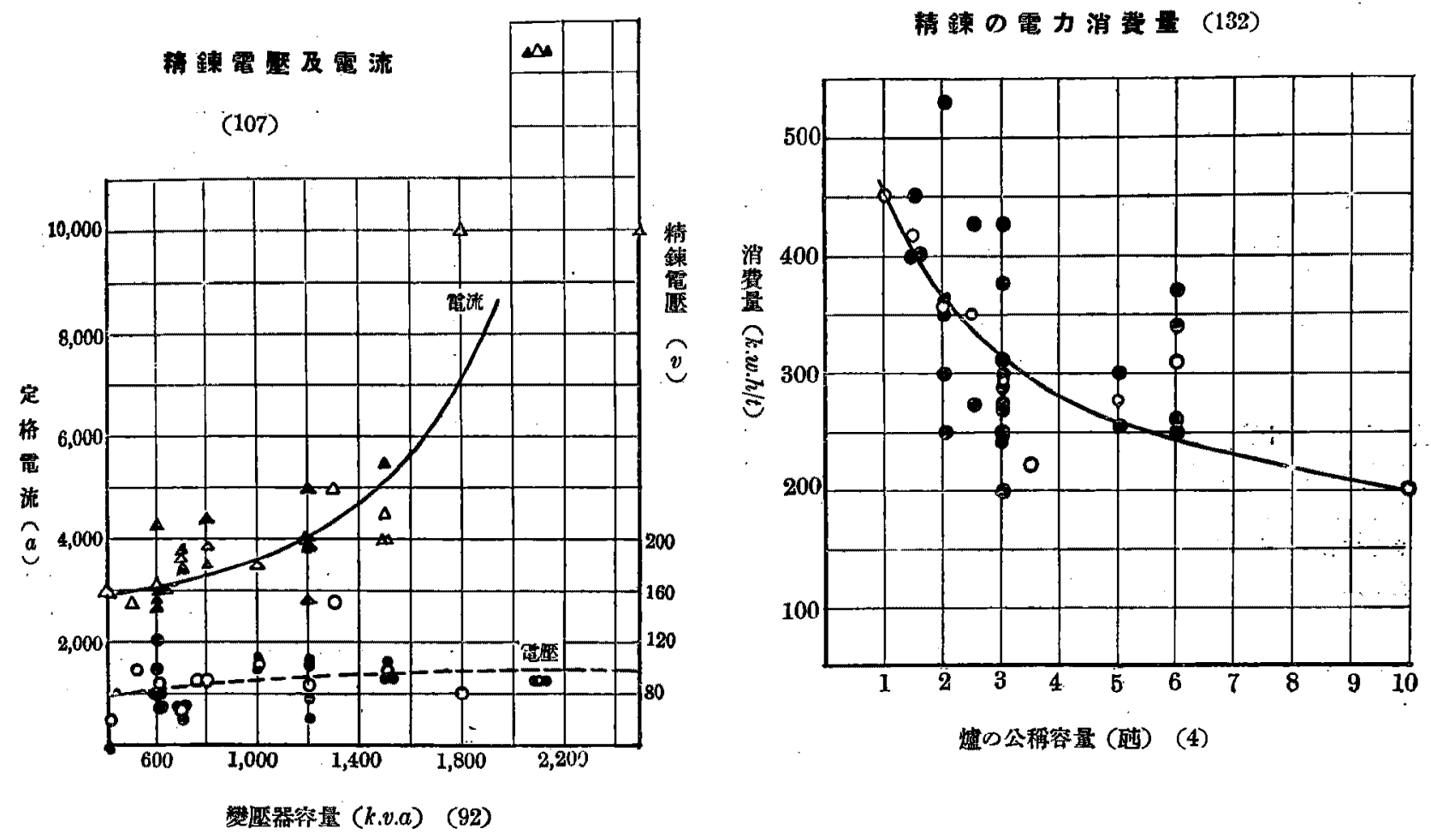

迭電より鉻解迄電力消费量（131）

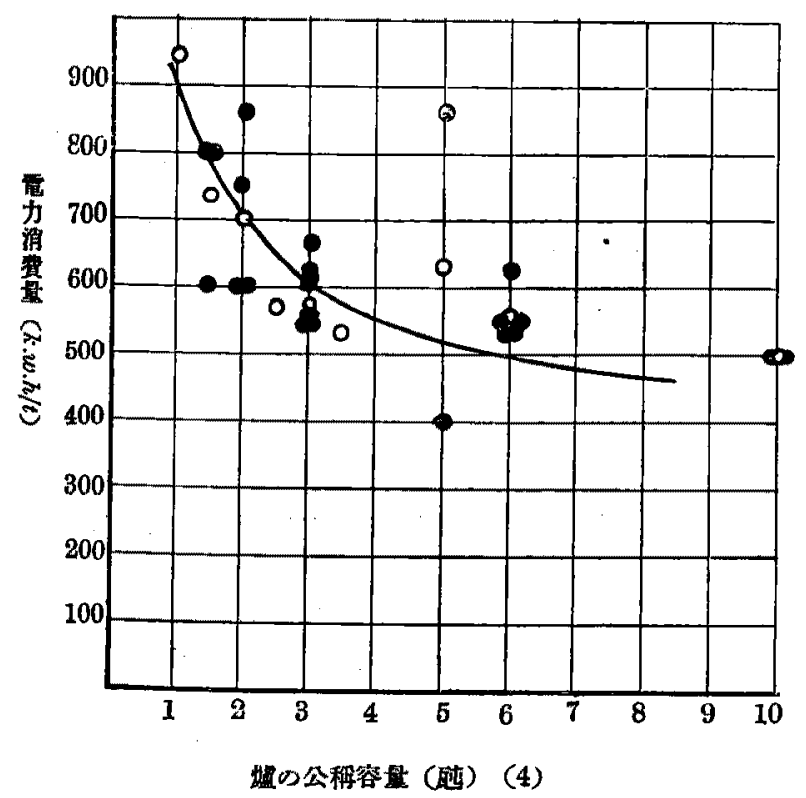

全電力消量 (133)

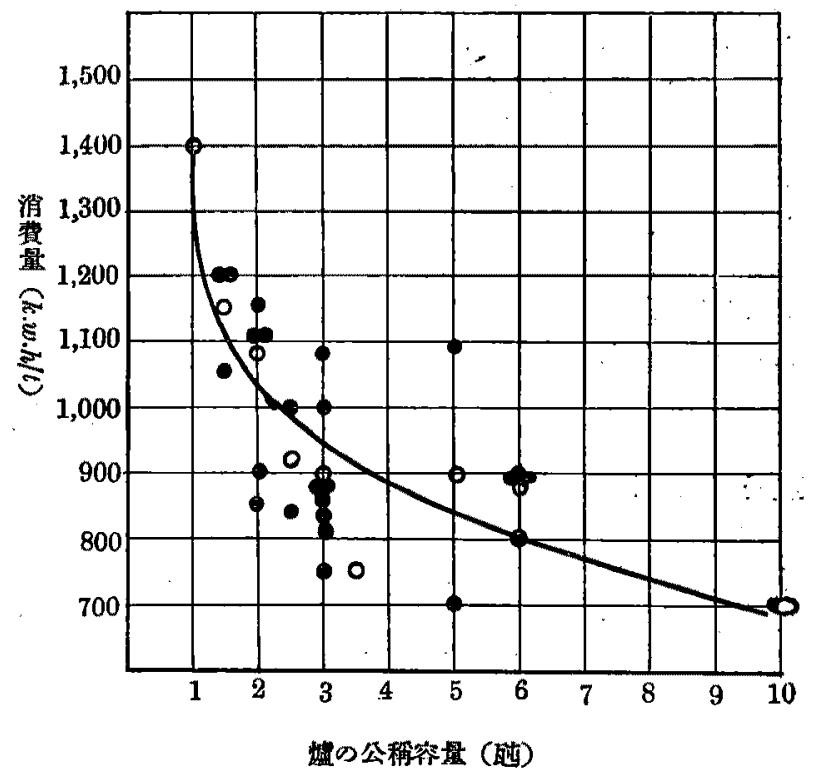




\section{VI. 開會の挨拶及委員長推蔍}

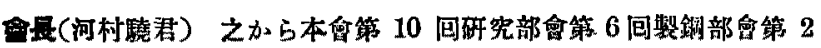

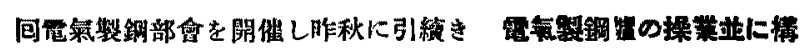
造に就き改蒡すべき黑如何なる議題を以て討检を始めたいと思

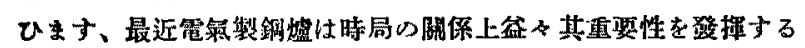

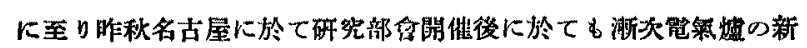

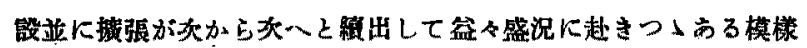

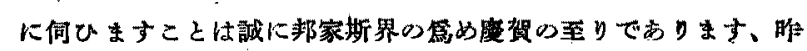
秋は午前中、檴演を御顾政し午後は概括的に討議を行つたのでる

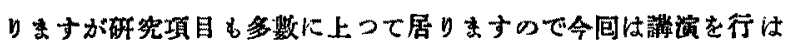

ず午前午後に亘り討議を玫すことになりました、何卒一居湅に入

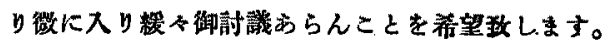

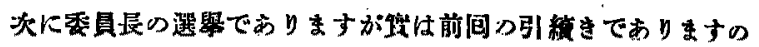

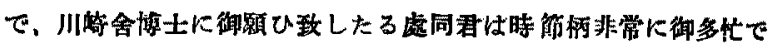

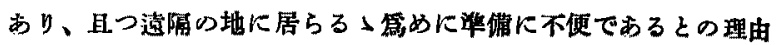

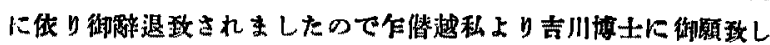

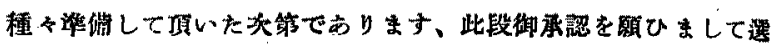
嚳を略したいと思ひます。(拍手)

\section{VII. 委員長の挨拶並に資料整理に就て報告}

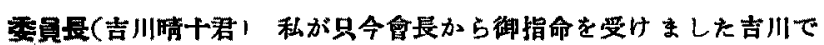
御座いすす。委員長として適任でないこと约自學して居りますが

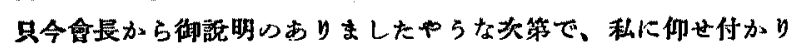
まして打受けを致した瀷でありますから、どらぞ本研新部會が充

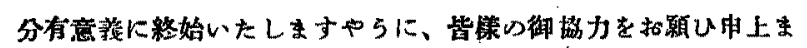
广。

借、今四心研究部會に於て侁議なさいますととを先般會長加ら

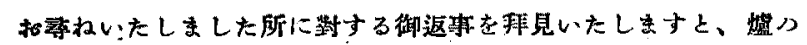

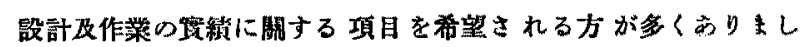

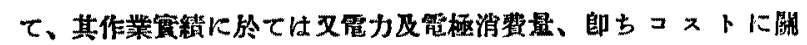

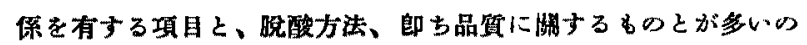
でありますが、是住取りむ直さす良品を安洒に作ると云ふ工業上 の原則から來て居るむのですりまして、愢しむに足らないことで あら5と存じます、刎椧樬ての项目が此原則に開保のないむのは

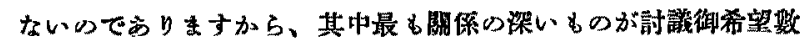
の最も多い綝果を現はしたものと思ひます、故に本來から申せば

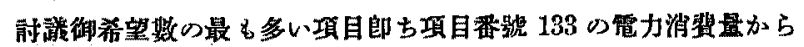

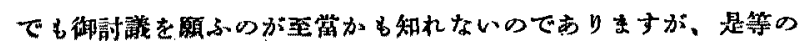
项目は何れる皆相關聯したものであり李すから、便宜上凟料一括

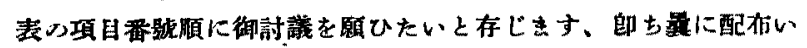

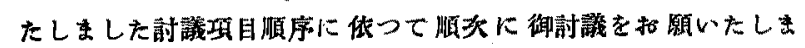
す。それから此討漾項目順序の表に包答と云ふ棚を入れまして、御

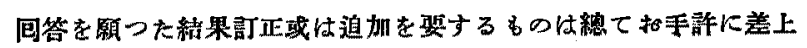

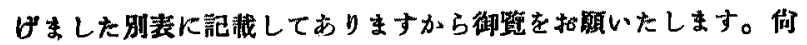
討議の便宜上、昨年秋の研究部會の箱揭げられはした、川崎舍委具

VIII. 討

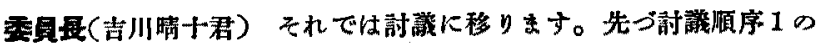

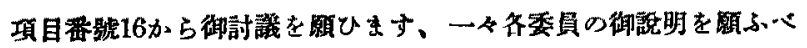
き管でありますが、特に御說明を必姦とされる力に机硕をするこ

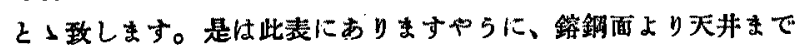
の高さのことですりりす、此表及圆表（16）を御筧になりますと蓉 しく其數字が相異つて居ることが分ります、2 啮の所で 350 と云

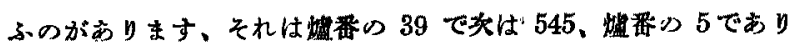
ます、それから3酝の所では数も大䋖多いのでありますが、バラッ

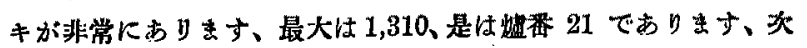
は 1,112 と云ふのが(嘘番 19)あります。6 赸の所であ大分迹ひ

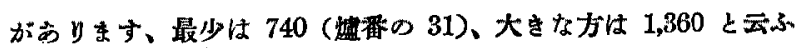
のがあります、(爈番 34) それから 1.296、(嘘番 23)。斯5云ふ心風

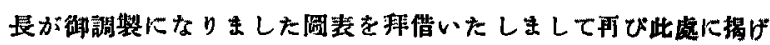

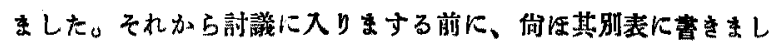
たるの以外に訂正を要する點があるさ5でございますから、石原 案員からそれを申上げます。

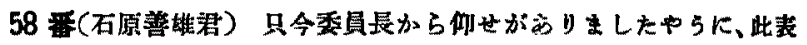

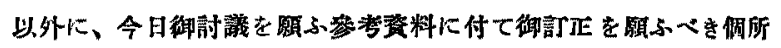

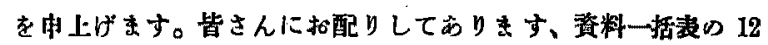

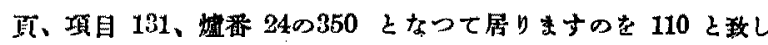
ます、是梳此前訂正になつたるのであります。それから炏の埴目 132. 嘘番 240600 が160、同じく爈番 29 の 180 200が 255、项目

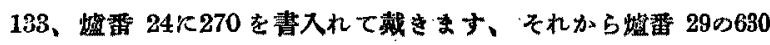
〜 700が 720、それから愐目 135、䗘番 39、力率の $90 \%$ が 80

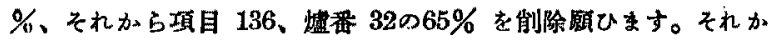
ら同じ項目で伐番 39 は60v となつて居て、記錄には 65 となつ

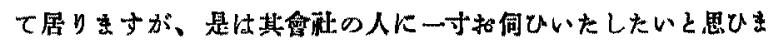

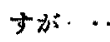

( 660 」叫ぶ者あり)

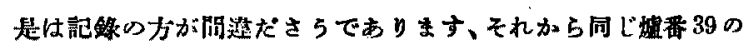

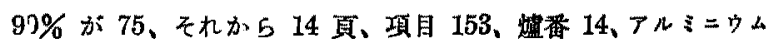
つ使用最が 05 になつて居りますが、03 に訂正いたします、そ

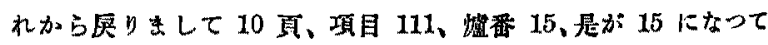

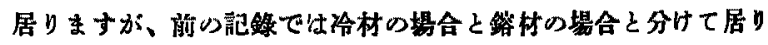
ますが、是は 15 だけで宜し5どざいますか

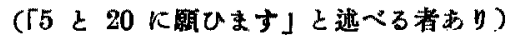

5 と20でするさらです。終り

\section{議}

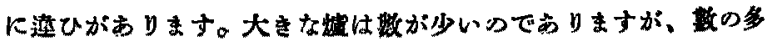

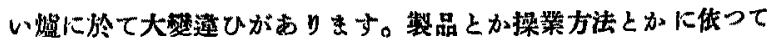

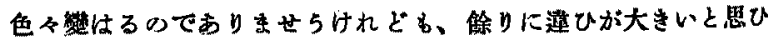

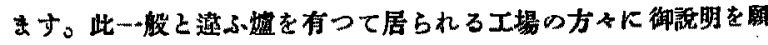
つて、それから討諾して戴いたらど5かと思ひます。先づ场番14

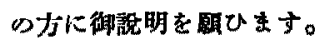

19 䙵(菊田多利男君) 此高さが大分低くなつて居りますが、普通の 丸型でなくて、展方形の形で、西極が斯53本业んで居ります。 其感に大分低くなつて居ります。

委是最(吉川晴十君) 榓 5 の方翻ひます。

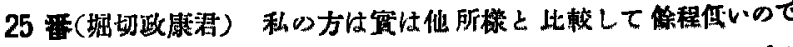
私の方で間題にして研㭝中でありますが、私の方では瑞唒のブす 
ウンボヴェリーの飭計を冰めて大體それを骨子として製作して空

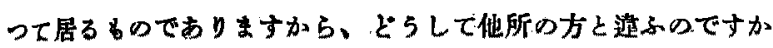
新しいるのですから、觜漛の据数一酷ひたいと思って居る位で

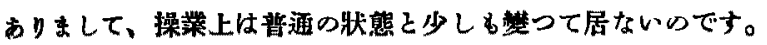

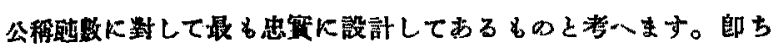

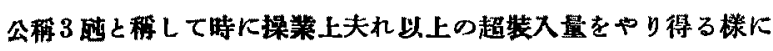
はなってみないのであります。

算是(吉川啨十君) 3 进の方の 17 番、矢張り同じやらなことで

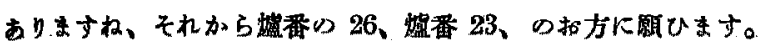

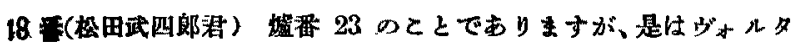

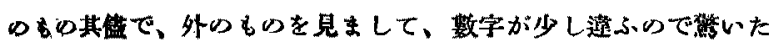
やらなととで、今まで䋡り天排心高さに付て開題を起すゃらなと そは巻いて量りませ妨。

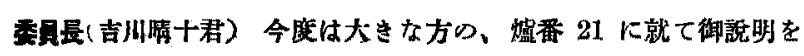
制ひます。

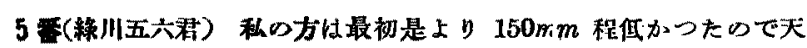
非を成るてく保大せる程りで、150 $\mathrm{mm}$ ばかり高くなつて居りま

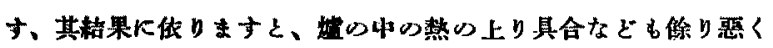

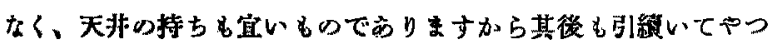
て居ります。

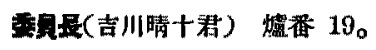

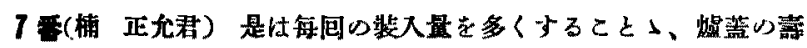
命を展くする箎めであります。

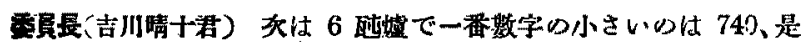
は嘘番い 31 であります。

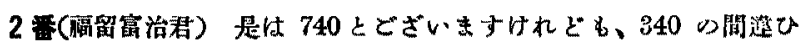

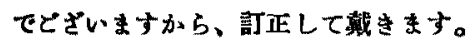

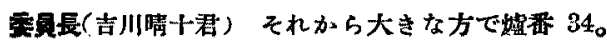

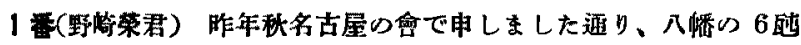
媌と云ふのはターニング、スクラップを云ふ非常に容程の大きい

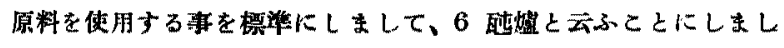
た、徙つて晋通のへヴイースクラッブを使はますれば、10画位の蛙

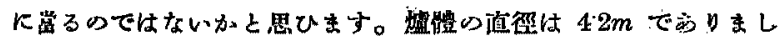

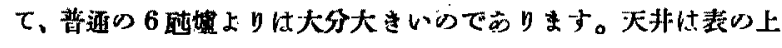
で代 $136 \mathrm{~m}$ の高さになつて居りますけれどる其後研究した結果む つと天井を高くしなければいか收と云ふので、只命め所で $14 m$ 以上に上うて居ります、天井をどれだけの高さにするかと云ふて

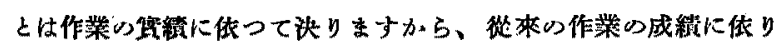
まして段々上げたやらな譯でどざいます、14m位で今の所でば非 常に結果が良くなつて居りますから、其の位が適嘗でないかと思 つて居ります、現在裴入量は 1 间に 8 䣩位です、表の上では天 井が高いやらでありますけれどる、䚺計の圆面から見ますると、 修り高いと云ふやらな事はないと思ひます。

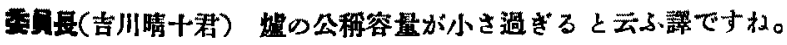

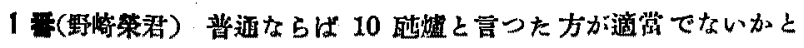
思ひます。

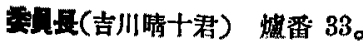

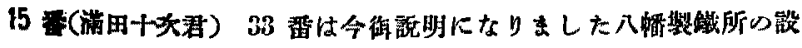

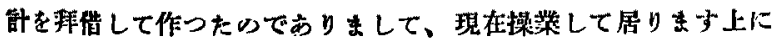

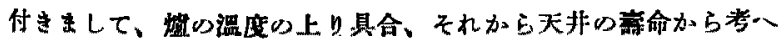

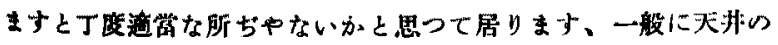

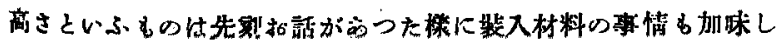

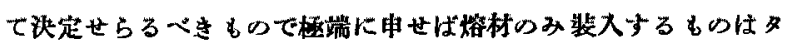
ーニングスクラップを多く使用するものよりる低くして良いと思

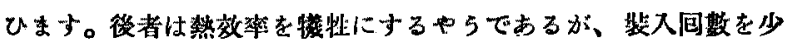
くすることによりその幾分を取返すのですัすります。併し天井が低 きに失すれば一面に於て熱努率以上の損失を招ぐを思ひます、そ れは天州が流水易く操業に困難を本し綃局良銅を得ることが出柬

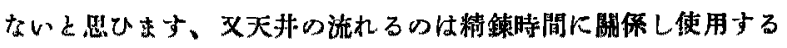
ボルテージにも閵保すると思ひます、綃局私は（1）その工場の使 用原料を考八(2)ボルテージを加昧して（3）精鋽時間の舆短に上 り即ち製作省留に上り操鄴して殆んど天井の流れないで順調 に操業し得る高さを最む良い高さ之思ふのであります。

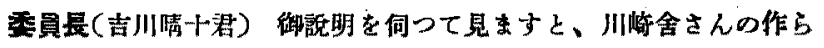
れた表に合ふやらに存じます。さらしますと特に但い所の烟番 とか爁番 17 とか云ふや5なのは天并がよく流れると云ふ中5な ことは御释瞼なさいませ收でせらか。

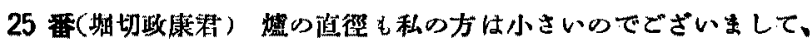

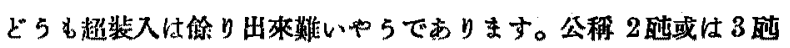

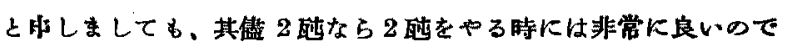

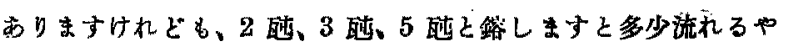
らでございます、故に現在御注交を受りて新橴を製作する場合に

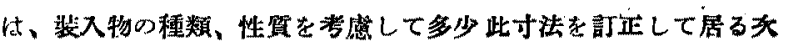

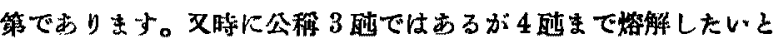
云ふ御希望の所もありますので斯る場合にも夫々㛈虑して製作し て居り末す。

委員長(吉川晴十君）悉だ他に御意見がありませ5か。

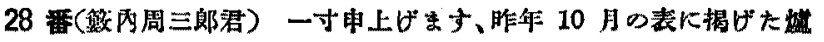
住此 2 月からエール式に算人ましたが元は $1255 m$ になつて居 りましたから离い方でありました。元の蜆はスナイダー式ででざ いますから、天井を明けて裝入をするやらになつて居りますので、

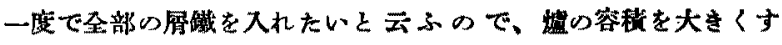
るのが一因になつて居ります、す5一つは商さはすつても電医は さ5高くなかつたのでどざいますけれども、㧤硫をやる中らにな

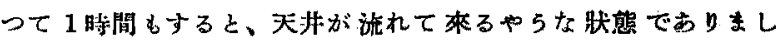

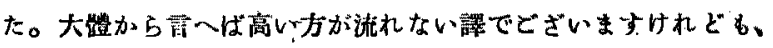

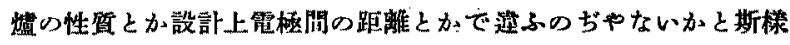

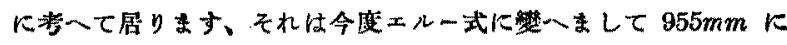

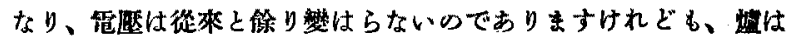

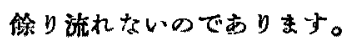

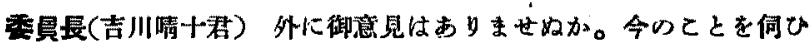

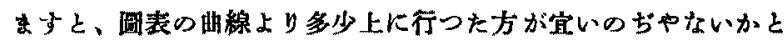
思はれますが、どらでありませらかっ。

1 番(野崎策君) 一寸御警考まで申上げます、天井を餎り高くする と電極の消䩀量が多くなります、低いと云ふと管極の消瓷量が少

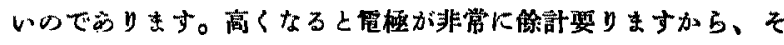

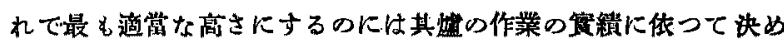
た方が宜くはないかと思ひます。

委真長(吉川啨十君) 情に依つてと申しますと。

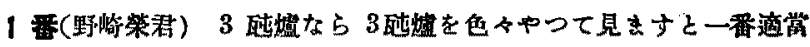
な所が見附かりさすから、それに作つて決めた方が䓝くはだいか

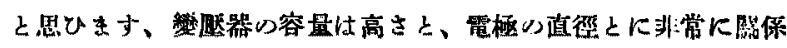

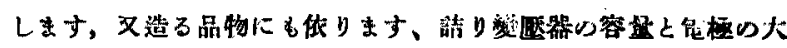

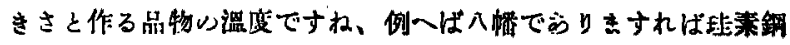


のやらに非常に熱の高いるのを造る場合と文低いものを造る場合

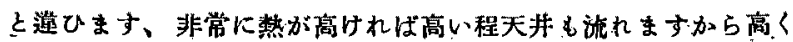
する、其代りに、電極が餘許要る、先づ之の問题は鋼筧に依つて 決凶た方が筧いのぢやないかと思ひます。

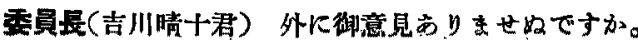

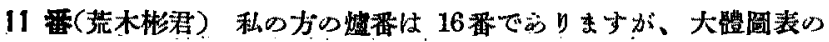
曲線に一效して居ります、一寸低くなつて居りますけれどむ殆

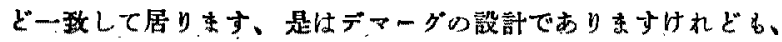
察際作栄した綃果は、非常に具合好く出來て居る漛に思って居り

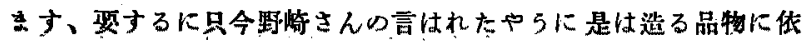
り、それから材料に化ることが非常に多いのでするると思ひ市す。

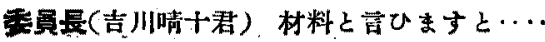

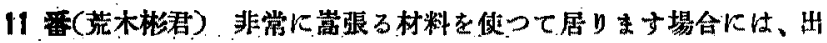

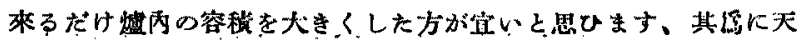
并を高くします、非常に良い理想的な材料の得られる所では天非

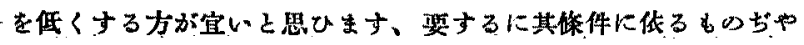
ないかと思ひます。

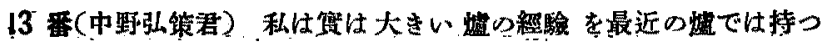

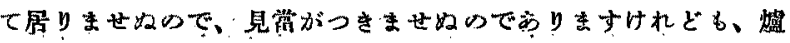

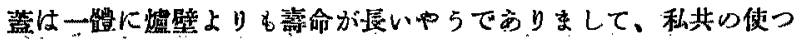

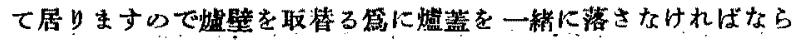

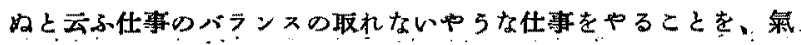

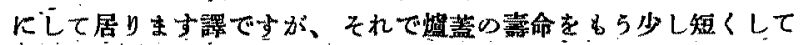

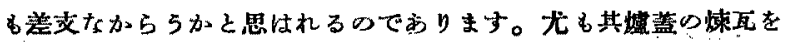

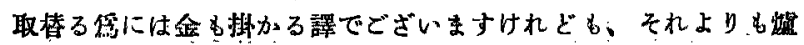

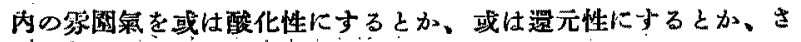

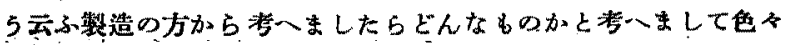

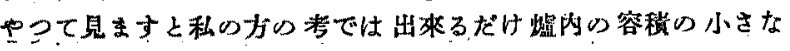

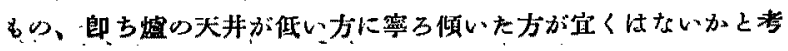
一七居ります。

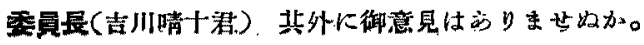

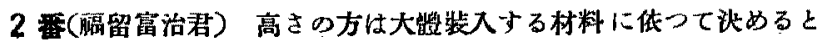

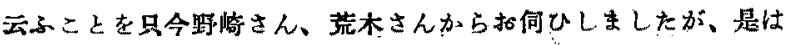

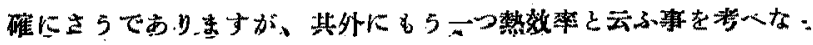
け机ばなら好と思ひます、天井の方で言ひますと、俆り高いと熱效 率が惡い、低い時には熱效率は宜いのでずが、其代りに天非が流 れたり、異命が短いと云ふゅらなことが必ず起るのですりりして

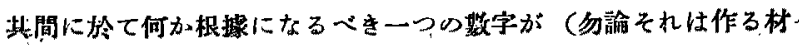
留に做つて连ひますけれども)あるいぢやないかと思ひます、を れでそれはど5云ふすのに依つたら宜いかと言ひますと、大䑩酗

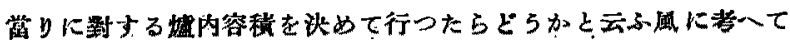
居る次第であります。进當りに對する客敉をどれ位にするかと云 ふとをを決めて行つたら大凡心經驗上に得た数字が現はれるのぢ

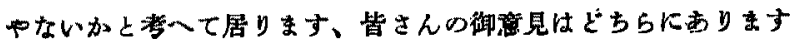
か何ひたいと思ひます、それで此随の内容穔と云ふととを、大能 去年の名古屋の大會に於て發表された㾞料から計算して見たので

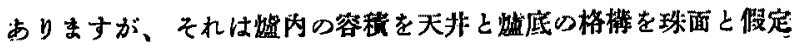

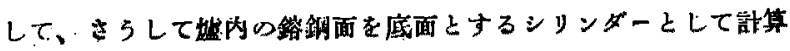
したものでありますが、それに传つて平均を取つて見ますと、大 體故に與一られた数字を基本上して $07 \mathrm{~m}^{3} / t$ と云ふてとになつて

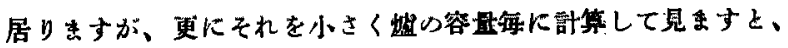

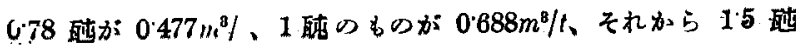

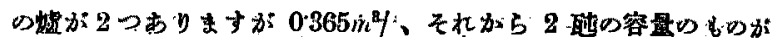
是は 5 つ市りますが、之を本均いたしますと $0696 \mathrm{~m}^{\mathrm{a}} / \mathrm{t}$ 、それ

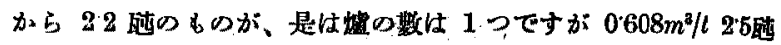
のものが 4 つちりますが其本均が $0668 \mathrm{~m}^{8} / t$ 、去れから

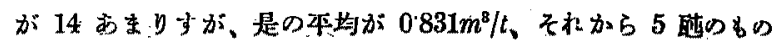

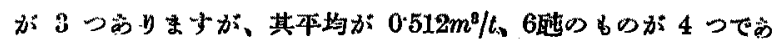

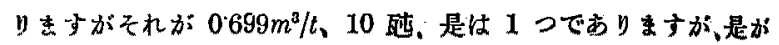
$0.408 \%$ 、斯 万云ふ風になって居ります。

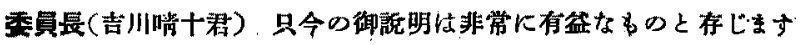

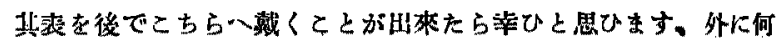

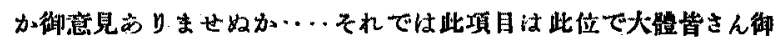
了解になつたこと〉思ひますので、狄に移ることに敉します。

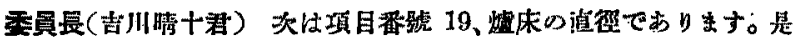
む亦著しくバラついて居ります。尤す此始床と云ふのは調查䙹

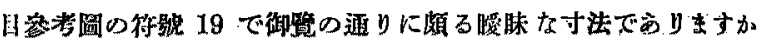
ら根道するのも無理はないと思Uます、唯 3 能の所で $24 m$ と云

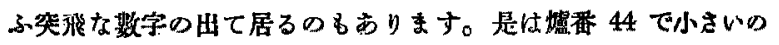

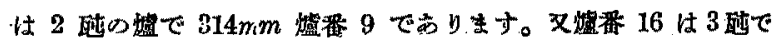

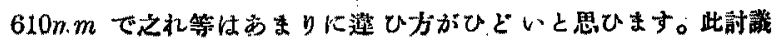

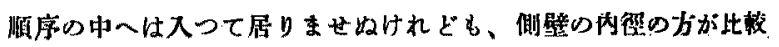

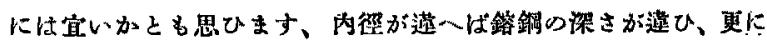

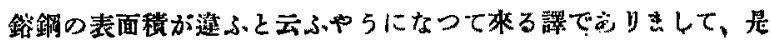

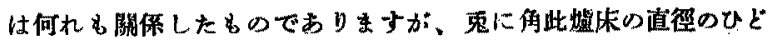

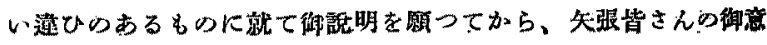
見を何つた方が宜くはないかと思ひます。爐番 44 の打方は括山

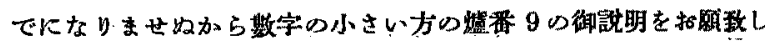
*t。

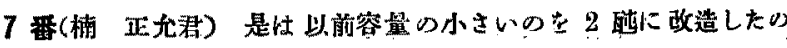

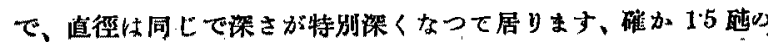
を2酗に改造しましたものと思ひます。

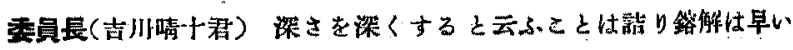

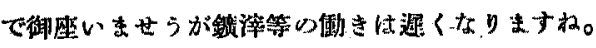

7 番(楠正允君) 深さを深くする㭙は表面りみは早く路㑇しますが

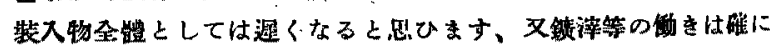

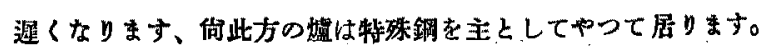

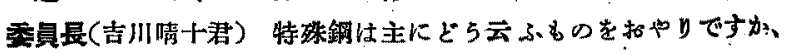
晹の深さの深いものは此重の大きな合会材料を入れるを底で固つ てしまふと云ふやらな盧むある誈でありませう。

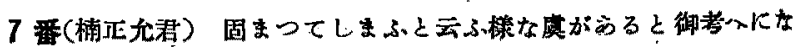

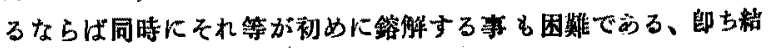

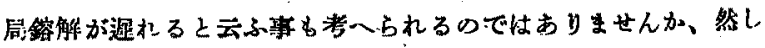

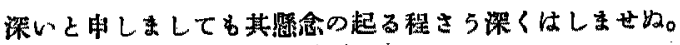

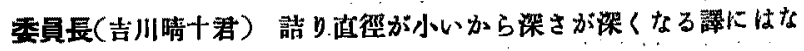

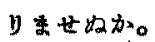

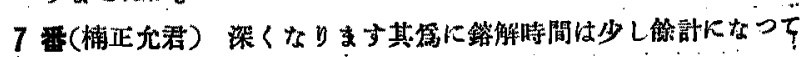
居ります。

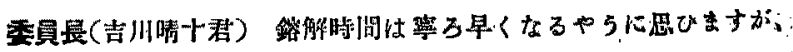
さらですりませ好、知張り小さいのだからしてェレタトロード

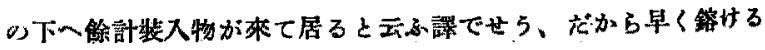
と云ふ臎になりませ汸加。

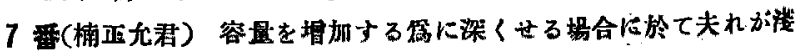

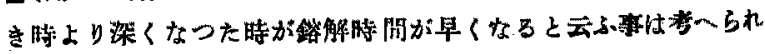




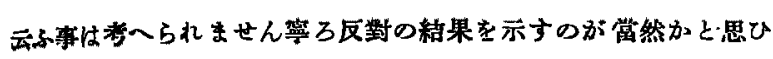
ます。

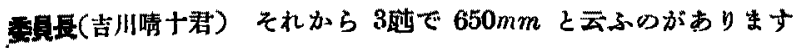
が虫 24 香です。

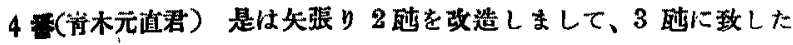

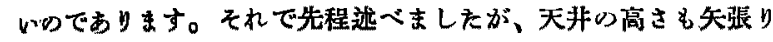
ありカーヴ(揭周の 15)加ら下の方に行つて居ります、をれで 土堤を作りまして、さらして 3 连を欽㑇して居ります。

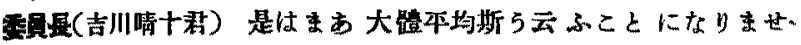
5。何加外に御意見のある力はありませ好。

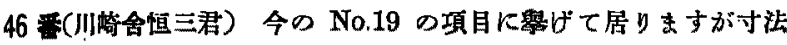

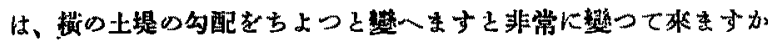
ら、此寸法をカーヴにプロットする事は俆り意竓がないと思ひま

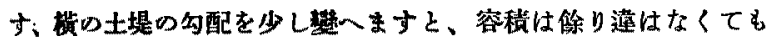
No.19 の可法は甚しく相違が起るがて思ひます、從つて之をかー ウに依つて適當な寸法を御決定なさると云ふことは餘り意味がな いちらに教人ま。

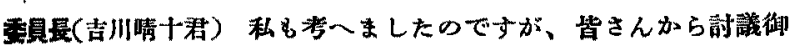
希望船が多かつたので此虑に舉げたのです、それでそれに關渞し

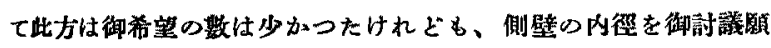
つたらどらかと考八まして、それで此发に其践表を並へましたの

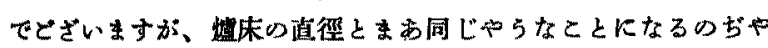
ありませ收か、其内徑なるものが圆表で御筧の通り矢張迋ひがあ ります從つて高さが逵ひ、表面程が虺ふと云ふととであれば、是 は作業上非常に重點上思ひます。是が俆り遥ふ上云子事は何加特

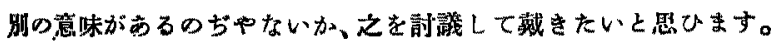

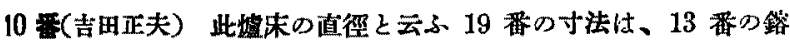

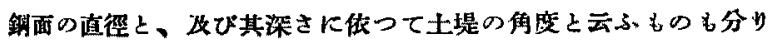
李す。其土堤の角度は最初の設計した時の角度を維持し得るゃ否 やと云ふことが非常に大事なととだと思ひます。

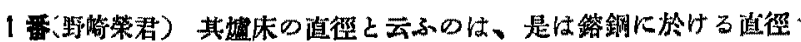
と直した方が道㗬ぢやないかと思ひます、さ5しませ收と、川崎

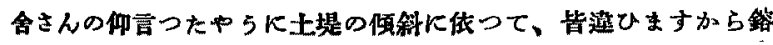
銅面に於ける直徑なうば、其點は大した變りはないと思ひます。 蛙床の直徑と云ふのはど5る誤解があるのぢやないかと思ひま to

顛長（吉川睛十君）それで川崎会さんの言はれるやらに、私はど らかと思つて居ります。

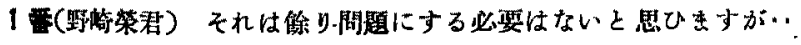
.

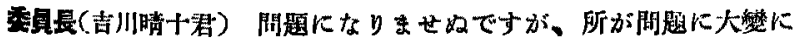
されましたのです、さら云ふ意味で討議をやると云ふ御希望であ。 つたかと思ひさす。

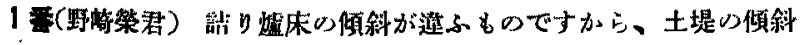
の方から波めなけれは其方が非常に美が多くなるでら・と思び s。

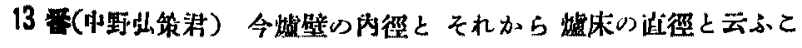

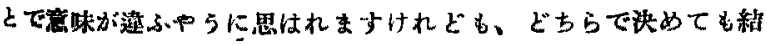
同は同じものちゃないかと思ひます、それは何敞かと申しますと

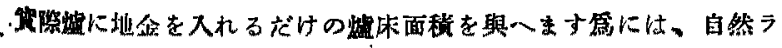

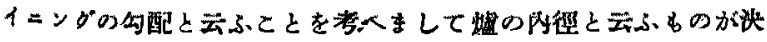
るいですります。其始床の勾配は、スコップでマグネシヤなど。
を投げてやりますと、自然に或る角度を保つやらな狀態になり勾 配は一定して來る譯でかりりす。それからライニングには或一定 の厚さを與一なければなら物、其厚ざが厚過ざると云ふと安全に

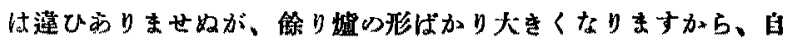

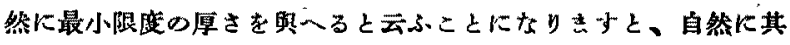
ライニングの厚さむ头つて來ます、從つて堵床に於けるライラン

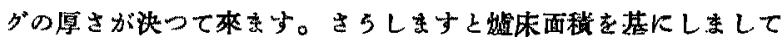

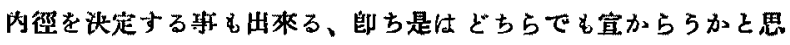

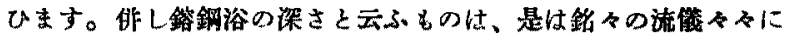
依りまして淺くする㭙には植休面稍を大きくしなりればなりませ

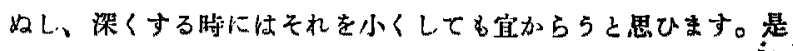

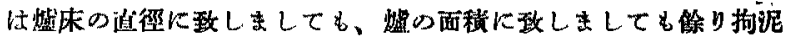

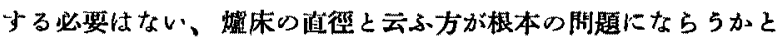

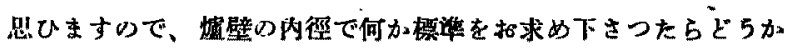
知らんと思ひます。

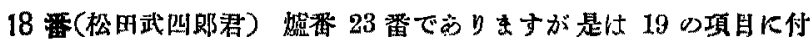

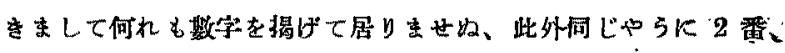

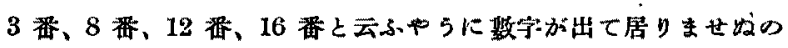
は、只今私が申し上げるのと同じやらな意味ぢやないかと思ひま

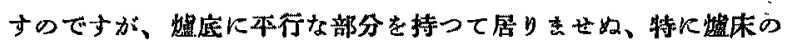
㨁德の数字を揭げて居りませ收のはさ5云ふ意味であります。

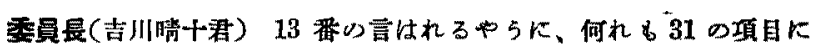

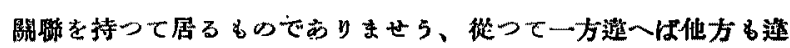
ふと云ふことになると思ひます、それに拘泥しない方加宜いと云 ふ㩐に纯い加ないと思ひます、それぞれに理由があります、理由

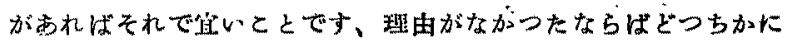
附くびきのではなかららかと思ひます、それに付て注突飛な：

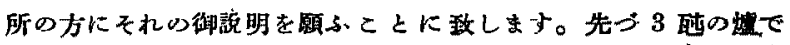
$15 \mathrm{~m}$ と云ふのが方ります、それは梏番 17 番で的りますが、先刻

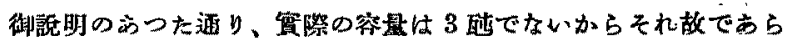

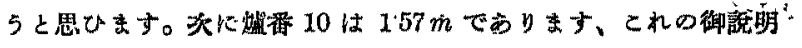
を願ひます。

34 番(恒松成光君) それは矢侲り公稱が少さいのでございます。

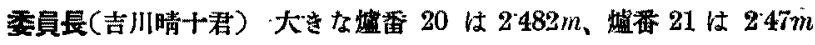

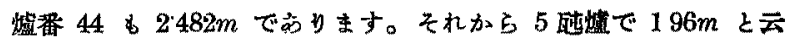
ふのがあります、是恃爐番 30 です。

21 番(中村道方君) 內德が小さ過ぎると仰つしゃるのでせ5か。

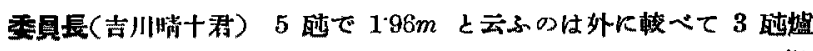
位の所火管つて居ります。

21 番(中村道方君) それは色々な裝入をやるのも一つの理由であ

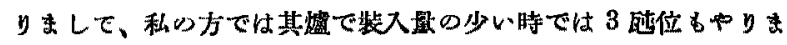

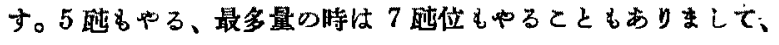
不同の装入最をせる關係から需力及電極消費の點を宩八まして队 鲉を此程度に數しました。

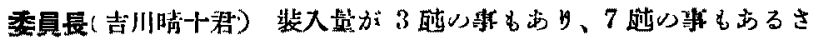

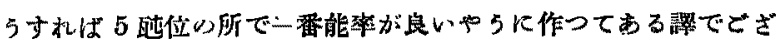
いますか。

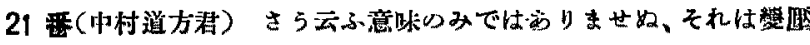
器の客量已。關俰しで居ります、之は 1,800k.v.aになつて居り

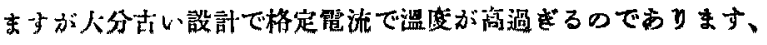

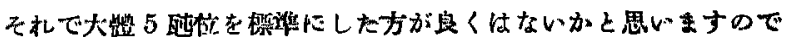

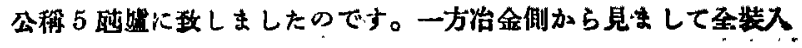




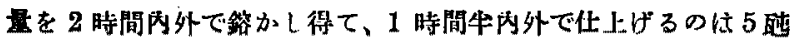

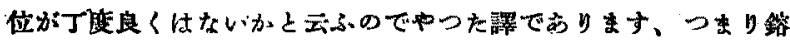
かす速さとそれから仕上げる時間との方に重きを值いた譯でずり

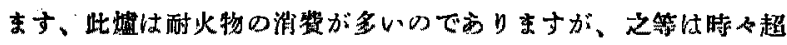
量留入するのが主なる原因であります、その代りに类的欽かすと 云ふ管味から商、ば相賞良い絬果を示して居るだららと思つて居

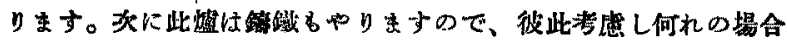

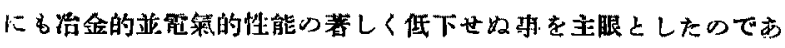
りす。で大體私は其造万物の種数とか其櫖が初めどら云ふアイ デアで設計されて居つたもので、それが其後模漛智されて目的を

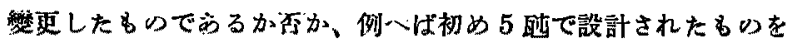

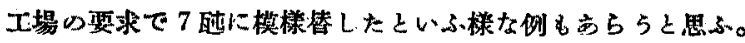

斯る場合初め上り 7 迪儿設計せるむのと總ての點で际りを生ず

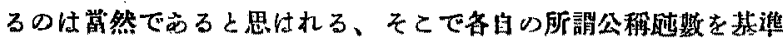
にして数字を出して見た所で雨りを生ずるのは當然の粎に思はれ ます。

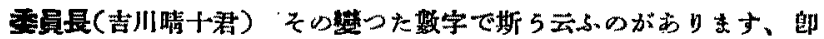

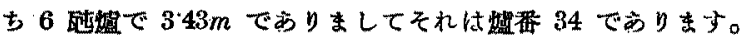

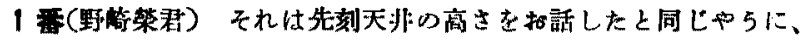

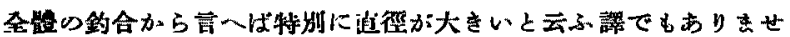

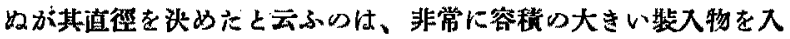

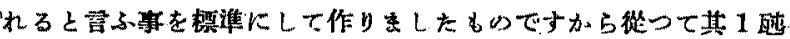
常り山容程が非常に多くなり志す。焱つて值徑も大きくなつた䛨

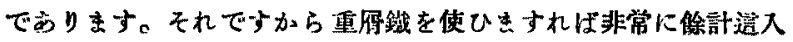

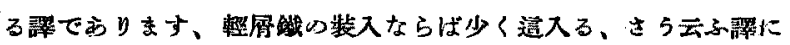
なって居ります。

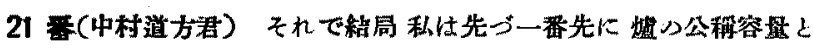

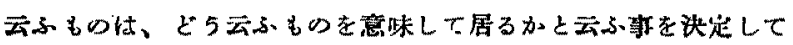

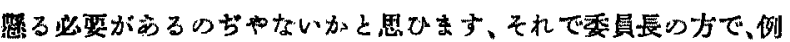

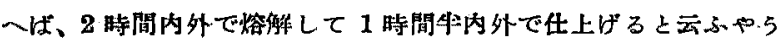

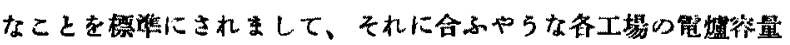

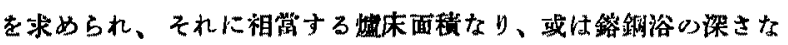

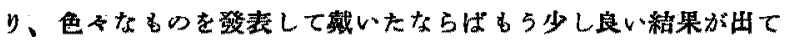
來るのぢやないかと思はれるのですが、訮心の所謂公秤容量と云-

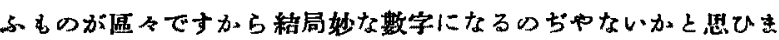

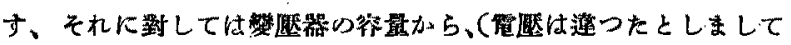

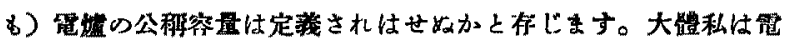

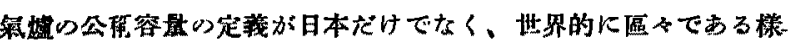

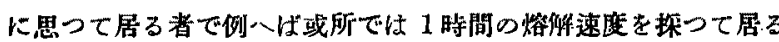

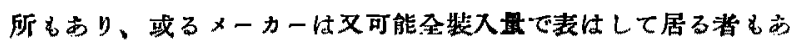

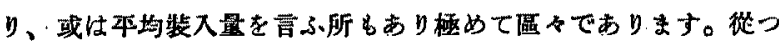

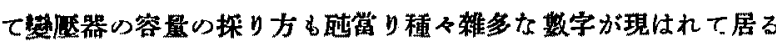

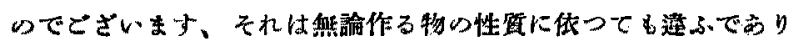

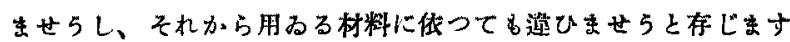

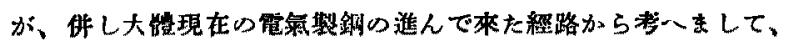

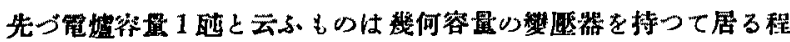

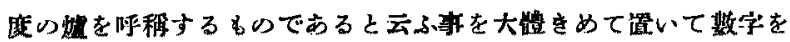

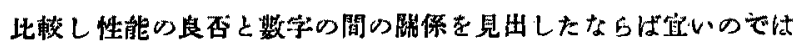

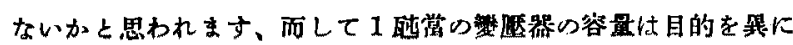

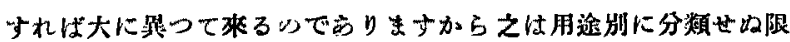

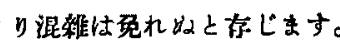

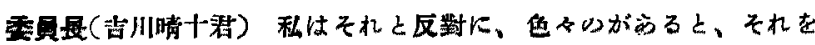

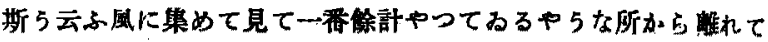

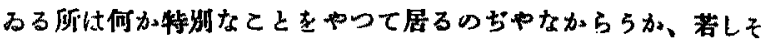
れが矢張り同じャ5な原料を使つて、同じゃらな物を作る吹笑

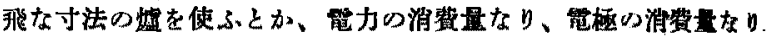

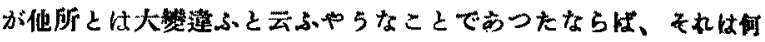
か外に中り方の違小所肪あるいであららから、それを撚し出して さ5して他と同じや5に中つて見ると云ふ心に風にて行くのが造步

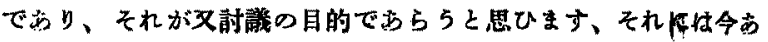

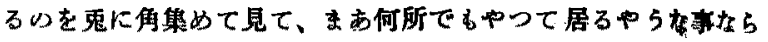

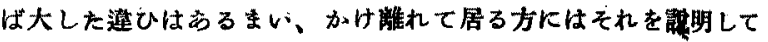
鿓ら、さ5して其墩明で皆が納得したら、それで特來いやって行

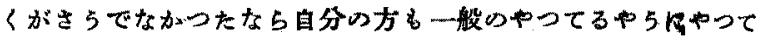
見やらと云ふ風にしたらよいと思ひます。夫れによつて牦封間で

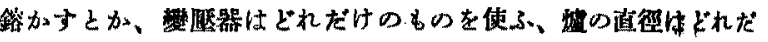

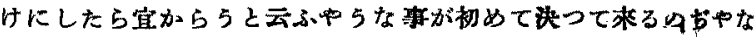

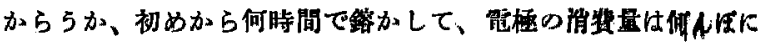

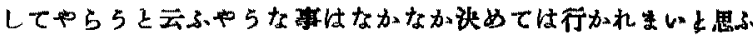
のであり来す。

21 要(中村道方君)：それは能く分ります、さ5云小来で行加ると

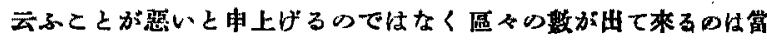
然であると申す者ですりまして、委員長の御方針通りで、不良性 能医正の目的は澾せられると存じます。

委買長(吉川晴十君) 外にまた普通のやり方でやって居るけれどい 良い銅が安く出來るから渱明してやららと云ふやらな方が南れば 妓で额朋して戴けば結满と思ひます。

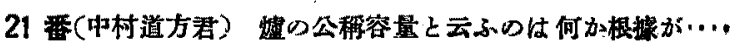

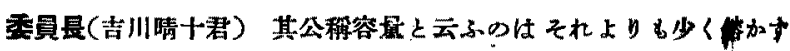

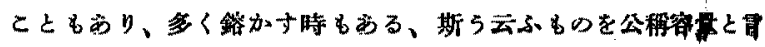

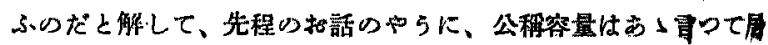

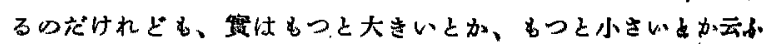
事を御詆明碩一ば监さんが綊得が出來るだららと思ひます。

21 (中村櫬方君) 分りました。

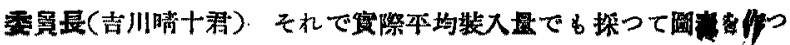
て見ましたならば或はもつと合形的の曲楾が得られるのいとに存

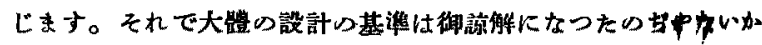
と思ひます。

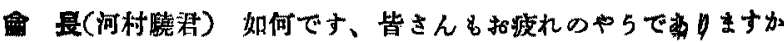
ら5 分ば加り休热致しましては…

委員最(装川啨十君) それでは一寸休みます。 (午前 10 時 50 分休热)

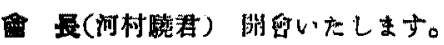

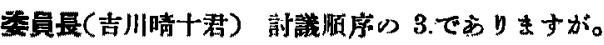

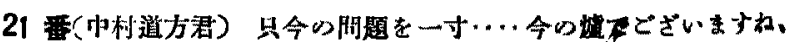
も5一つ态れて居りましたのですが、かれ数然器が古い設計で

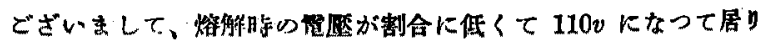

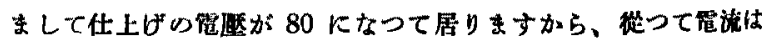

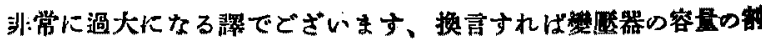

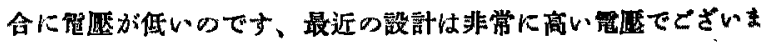

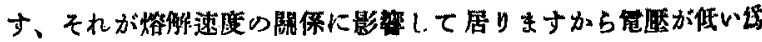

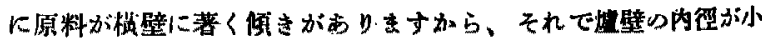
さくなつて居ります。

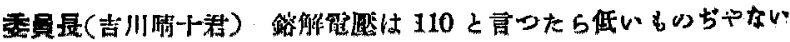


と思ひすが。

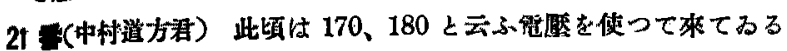
時代でありますら。

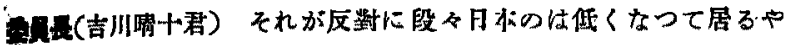
5К思ひます。

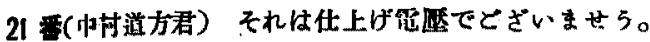

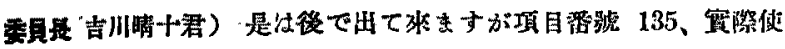

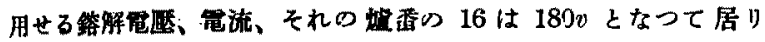

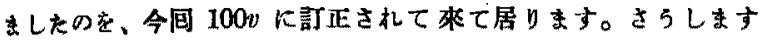
と 110 と云ふのは低い方ではない中らに婜ひます。

21 雨(中村道方君）それは今の此表にる高いのるすりますが大體

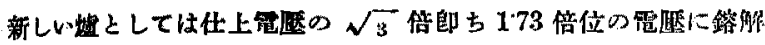

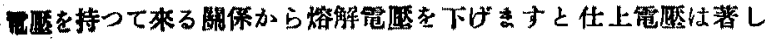

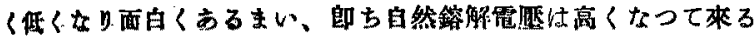

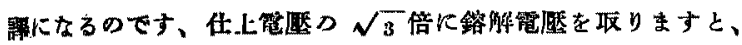
100vで仕上げますと、173v ばかりになるいです、無論さら云ふ

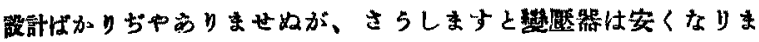

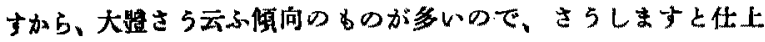

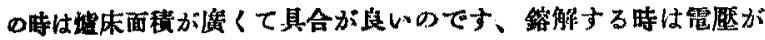
高い筒にずつと遠距離つるのまで早く鎑けて行くと云ふのであり ます、私の方は仕上の電歷が 80 で、鎔解電晨が 110 なんです、

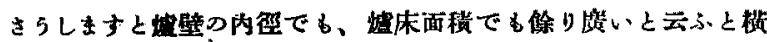
Кくつ附いたやつをかき落すのに眼がかかるのです、さう云ふ關 保加ら比橔的小さくなつて居りす。

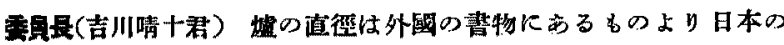
はの」方が少し大きいゅらです。

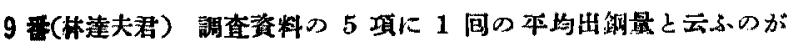
出て居りますが、爐の公䑧容量で此曲線を决めるょりる、1仙か

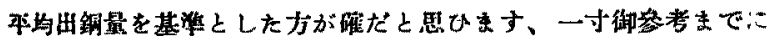
申上げて䇥きます。

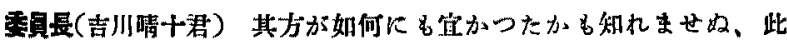
四表は川筞合さんのを拜借した摆ですが、川缩合さんが此圖表を 作られる㭙にさら云ふからな根考がありましたか。

46 潘(川等念恒三君) 此前の研党部會の㭙は一旦公稃容量をアフ シッサに取つたので、後から弌が附きましたりれどる、時日がな かつたので、まの嫱出した譯でして、其後私の方で注今林君が

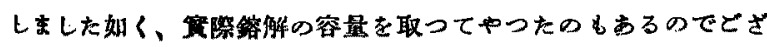
いますけれどあ、さ5云ふ風な大きな圆面が出來て居りませ好の て、持って愈りませ奴。

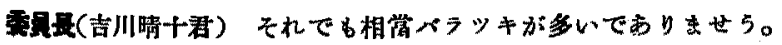

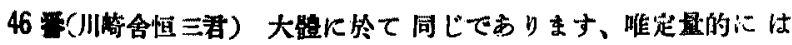
多少连ひますけれどし、定性的ては同じであります。

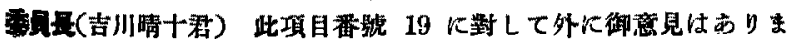
せ加。

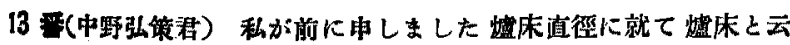
ふ事をハースと考人ました翋であります、私の考入で梳鎔制面を

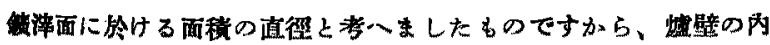

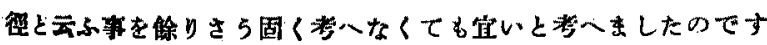
けれぞる、能く此附圆を見ますを、㛙床となつて居りますのは一

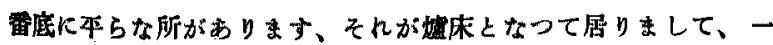
寸考人透ひをして居りましたから訂正して俻きます。

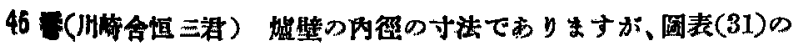

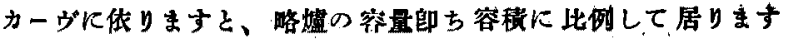

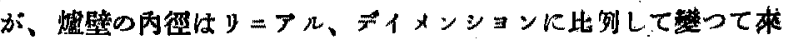
ますのに對し容量はキニービッタ・デイメンションに比例して戀 つて本るるのですから、若し容是をりニアルに取ると内鱼は立 方根儿此例して楚化することになる。㷋つて曲線は此線より下

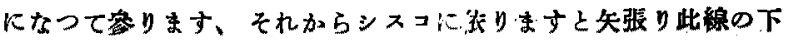

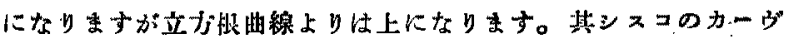
に依りましても立方根曲線よりる少しく大きいと云ふのは詰り精

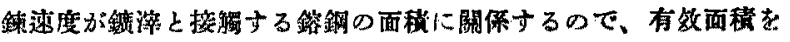
デイメンションの制合より多く抆ると云ふ理由から來てるるるの

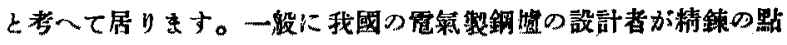

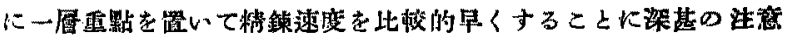
を排つて居ると云ふ小風に宩一れば、シスコつカーヴよりる此カー ヴの方が上に斿ると云ふ事の詆明が出相るかと思ふのでありま y。

21 雷(中村道方君) 今力拓話しで明かつ様であります、私が先到申

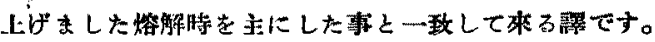

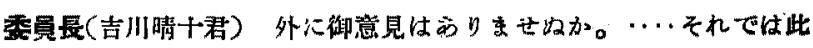
項目は㫕で終ります。

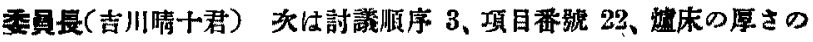

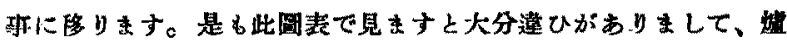
林の厚さと云ふと、大抵決つたるのぢやないかと思びすけれど 、、或恃大な整をキけパンテイーを小さくして使ふと云ふのも あるか子知れませ好ら、御話明を酸つたら如何かと存じます。

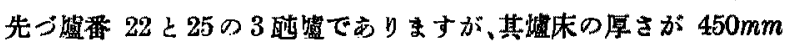
で、他っ 3 䣩点に此して非常に厚いるのになつて居ります。

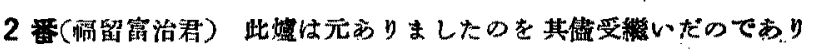
ますが、此 450 と云ふのは煉瓦と其上にマダネシヤ、それを全體 会めた厚さでありまして、此の外の方の情床の厚さと云ふのは上゙

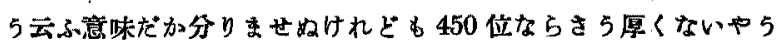

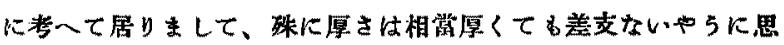

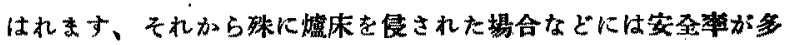
いので其位でやつて居ります。

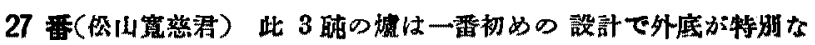
形のため特に厚くなって居りますが、6 䂾の方は薄くなつて居り ますタール・クリンカーを用ひて約 $240 \mathrm{~mm}$ です。

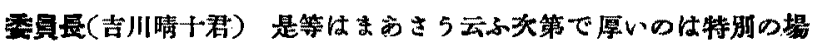

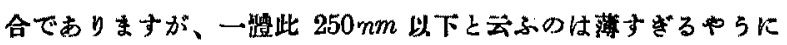
私は思ひますか、さ5云ふのが大分放ります。

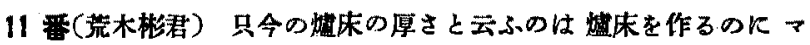
グネシャを使ふのと、ドロマイトを使ふのとで遮ひはしないかる 思ひます、私の方は $220 \mathrm{~mm}$ で稍其カー占り低いやらでござい ますが、マグネシャばかり俌つて居りまして、また晴休にトラヴ

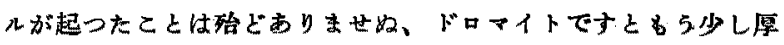
くした方が宜いのぢやないかと思ひます、マグネシャですをます その位で大丈夫つゅ5です、私の經驗では……

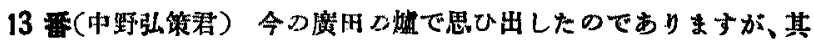

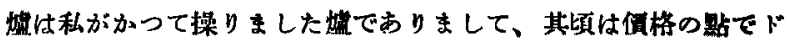
ロマイトを使ひましてマグネシヤを使はなかつたのででざいます が故障を起しまして危なかつたので、令度の䜖は厚くしなければ

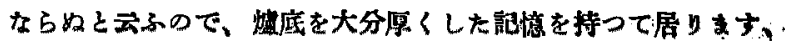


ドロマイドを使ふことにして設計しましたので、戴は厚くなつた のぢやないかと思はれます、ちれだけ責任上附加一て置きます。

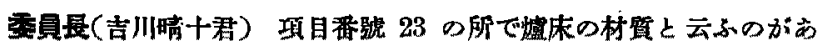

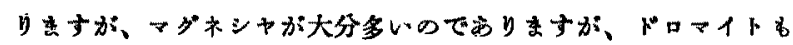

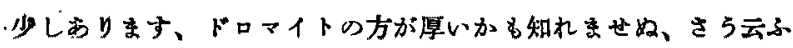

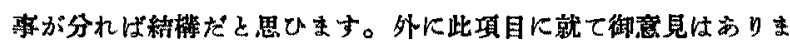
世好か。

悉野㥓然君）私の經驗ではドロマイトの方は厚さを厚くして、

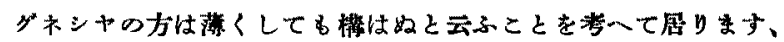

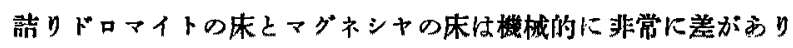

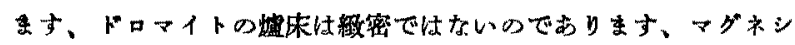

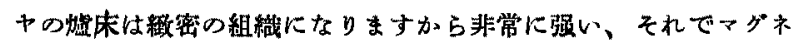
シャの場合とドロマイトの場合で厚さ索決めた方が良いぢやな がと思ひます、最近八幡の方で宽驗して見ましたのですが、マグ

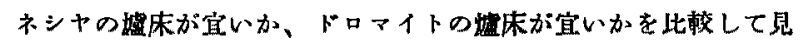
ますとマグネシャの方が非常に結果が良いのであります、マグネ シャの能床にしますと2年本位保てますがドロマイトの方は1年 位しか保てまは㰠、それで、グネシななら椓り厚くなくても宜い

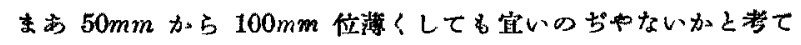
居ります。

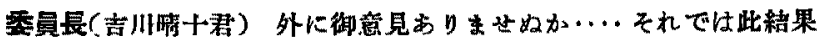
としては、ドロマイトは厚くするが、マグネシヤなら䕩くしても 宜しいと云ふ事が分つたと存じます。

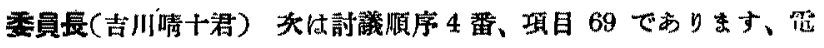
極の材孟、此材留に就ては前回の研究部合に於て種々御討議にな クましたが、更に䣓議御希望の數が多がつた所を見ますを、如何 に宠が重要であるかと云ふ事が镜仕れます、それで今一度妓で御 䣓議を願ふ狄第であります、今回戴きました御问答の中に人造黑

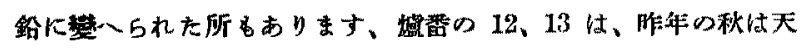

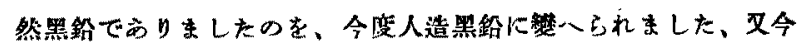

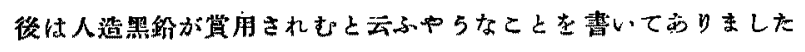
が、さら云ふ御意見を出された方出特ります、就きまして此方 ↔に一層詳しい拓話をして戴いたら如何かと存じます。

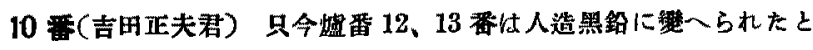
印剧して戴いて居りますが、是は諟りでした、從來通りの天然黙 鉛なんです、此データーを作る時に人造黑鉛電栖に變更したいる 思つでたのですが、未だ實施されてないのです。然し早晚低炭 素 $\mathrm{Ni}-\mathrm{Cr}$ 銅等に變更致し度いと思つてるます。

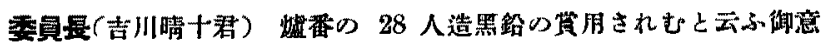
見を…。

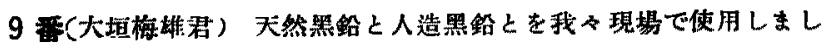

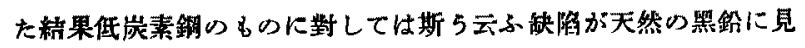
られるのであります、即ち非晶炭素が早く然えて行つた啳、グラ

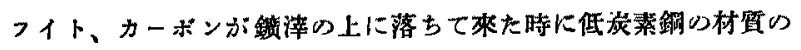
製浩に非常に天然黑鉛が不便ばつたと云ふ經驗を持つて居ります

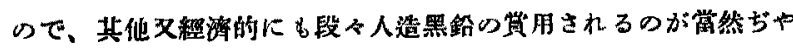

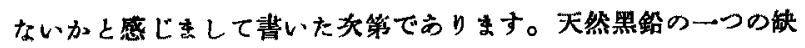

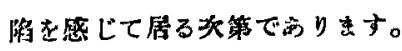

委員畏(吉川晴十君) 外に御澺見ありませ好。

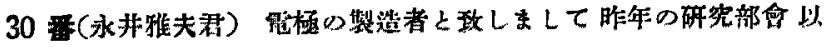
後調いました點を此際御報告本上げたいと存じす、教にし

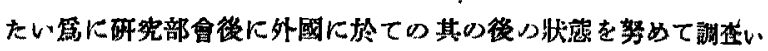
たして見ましたのです、所がそ礼が私等の宩人て居りました状留

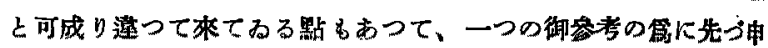
上げて見たいる存じます。それは丙地では御承知の酒り、人造黙

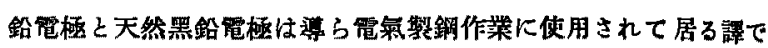
すが、外國では無既炭とがコークスを原料にしまして、所調非奛

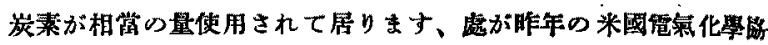
會の前剧に Nartn 會社の方が近狀を詳細に淑告して居りまし て、非昆炭素の管極心一步進みましたハイカレント・カーボン・ エレクトロード云ふ名前のむのが新しく現れて居ります。その 洋縕ははつきり分りませ始が、カーレントブンシチーの取方から 官ひまして、人造黑鉛管極と從來の非晶炭素管極の丁度中間にあ るやらです、これは新しい慜品であります、それから Vasburgh

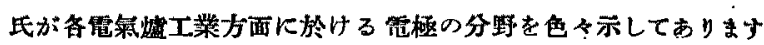
が、其中に管氮製銅に閶保するすのとして二つの方面就て考

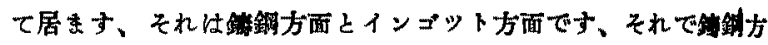
面に於いては、非晶炭素霄極とダフファイト、ェレクトロードの

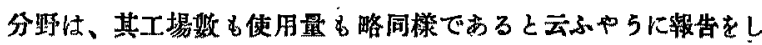

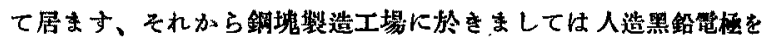
使用して居る工場数よりる炭素樘極を使用して居る工教場の方か

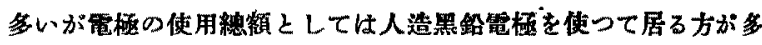

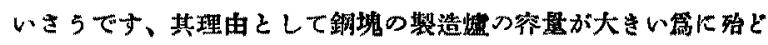

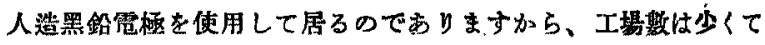
も需極の消热顧は其方が大きいのだと說明してあります、それか

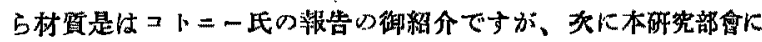

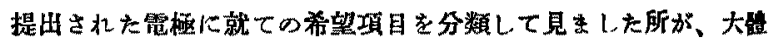

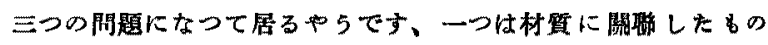
そ、それから一つは此使用为法に關保した。のと、も5一つは其 消费最とそ犰省少くする方法如何と云ふ三つの闍題になって居つ

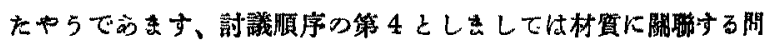
題のみに付て进べたいと思ふので御座いますが、材質に付て里大 開題になり末す點は何んと言つてす利害得失の點にあるだららと

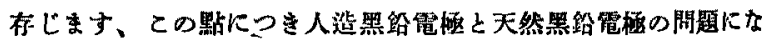

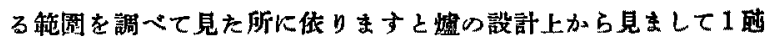

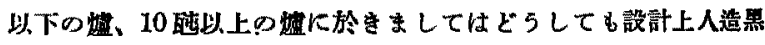
鉛でなければならぬのに承つて居ります、從つて其の中間の 3

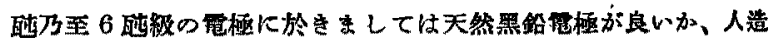
黑鉛電極が良いかと云ふ開題が起つて来る橉に考心すす、それか

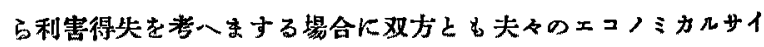
ズの狀息に於て比洨されなりればなら侬を思ふのです、それから 得失を諭ずる項目として大體三つの項目に付いて考へれば宜いか 々思ひます、其第 1 は品犋心得失です、で品空の點から言ひます

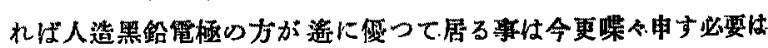
ないと存じょす、妓に特に品㧚に付て考ふでき點住均等性のこと

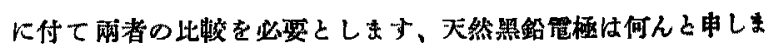

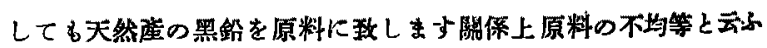

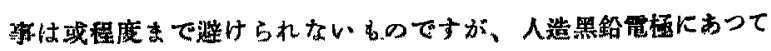

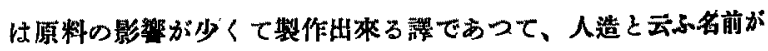
冠せられて居りますや 5 に、製造技街さ一僈秀なればその地等性 む遙に膯つて居るものです。

それから其次に第 2 の開題としては僄格の點です、其保格る

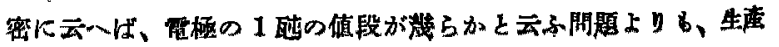




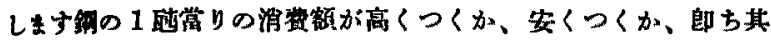

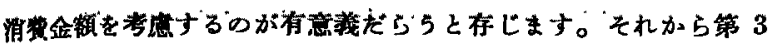
项目としましては、使用の條件を考虑に入れなりればならないる

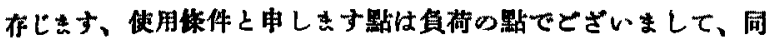

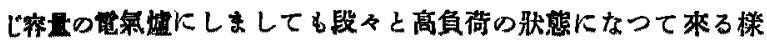

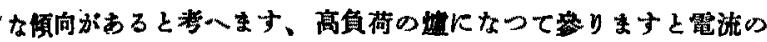

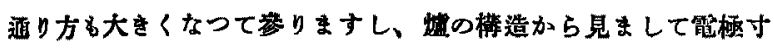

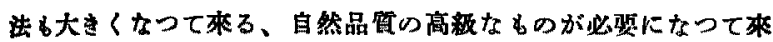

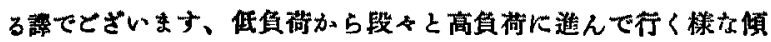
向であつてさら云ふ場合にはどらしても人造黑鉛䉓極の方に考虑 を㓝はなければならないかと存じすす、それから甥の設計上から 見まして、次心討識珼目にでざいますが、熋極の中心距晟を成る だけ诙くしたい、小さくしたいと云小點から申しはすと、筺極の 太さは的り大きなむのが得策でないことは明らかです、寸法に业

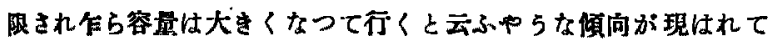
本るのぢャないかと思つて居ります、大䌡感じました點を一寸御 報告申上げます。

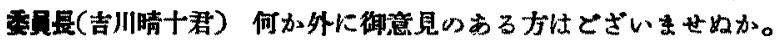

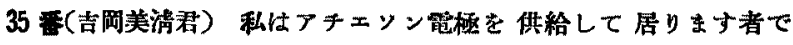
すが、令永井さんから詳しい括がかり主したので、殆ど電極供

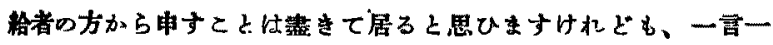

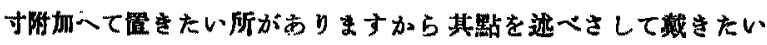
と思ひます、材筧と申しますとクォリテーと云ふととになります

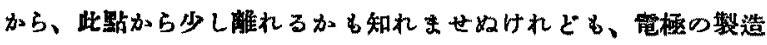
が非需にむうかしいと云ふ點は 2 策所あるのです、其一つは成形 であります、原料を適賞に處理をして、それをプレスに撕けて成 形をして、其後にベーキングフフーネスに入れて、それを焙硞す る、其仕事が非常にむゔかしいのであります、それで其成形が哭つ て居りましたならば、假令黑鉛化が完全に出本てる其電極の值打

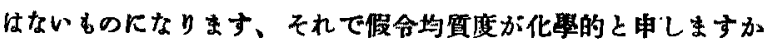
情理的之申しますか、完全であつても、其形が完全に出來て居な いと云ふととはど5云ふ事かと申しますと、例一ばクラックが入

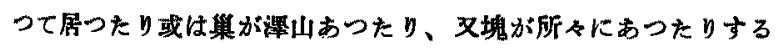

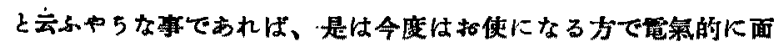
白く【い現象が起る、又後から閶題があるっらですが、析れたり なんかすると云ふ事が非常に多く現れて本るのであります、であ り寺加ら、村算心問題は、今永并さんの仰つた以外成形が 5 まく出來てわると云ふととが非常に重大な開題になるのです、一 寸此機會を利用しまして私が御注意を申上げたいと思ふふ事があり ますが、それは管極が如何に困難をして、非常に周密な注意を拂

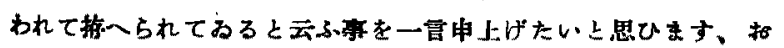

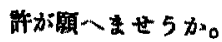

委是最(吉川晴十君) どら ぞ。

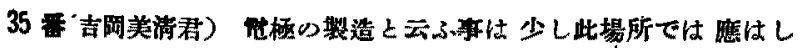
くないことかを知れません、管極の整蒌上云ふ事付て充分の知 識を得て戴きたいと云ふ趣意に依つて、一寸拓話したいと思ひま す、今据站がありましたやらに、外四では非晶炭素と、それから

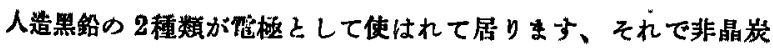

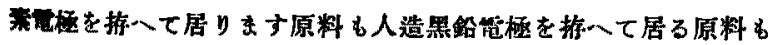
闹一々霄つて㖹しいのであります、先づ原料を粉碎してそれをブ レスК措けてさ5して所要の大さに作る方法が二つ而ります、そ いはメタメトルーダンヴを申しまして押出して作る方法上たール
ドと申しまして型に原する方法があります、を机でプレスに措け て出來た篦極をでーキングするには私はナショナルカーボンをつ チエンングラフアイトのカ法しか存じませかが、それに付て申し

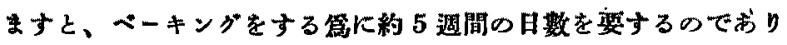
ます、さ5して出來ましたるのを旅直に检查して、さ5して燃に 入れて黑鉛化するのであります、其篇には 1 䓢閒から約 10 日間 の日数を要するのであります、さらして出来上りましたすのを敢 更に检查をして初めて市掦に出すのであります、でありますから

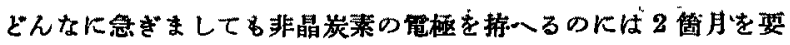
するのであります、人造黑鉛の電極を造るには 3 筒月を要するの であります而も其出来上つたものを敗重に檢查をしました時には 非常に步瑠りが惡いのであります、斯ら云ふ風にして推人られた

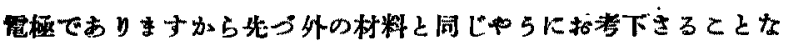
く、ぞ5ぞ麗極は斯 5 云ふ風に非常な努力を以つて据一られて居

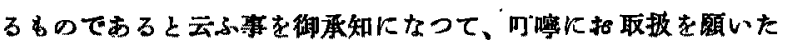
いと思ひます、後に笔極の取报方法などがござい゙すから、色々

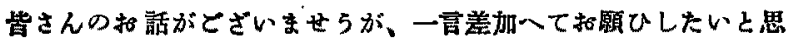
ふのでどざいます。

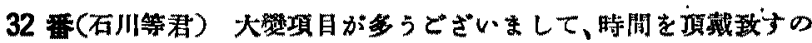

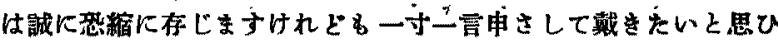
ます、それは只今一二の方の拓哲の中に諧外國で使つて居ります

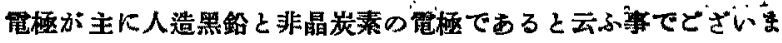

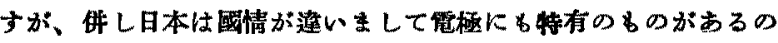
であります、御承知の通りに朝䱦恃世界で但秀なる黑鉛の地で す、份任近くは印度、セイロンK政しはしてめ、マダカメかルに 敌しましてを、可成り都合良く日本一原料を榆入する事が出泍る のであります、近來朝鮮から外國に黑鉛が算山輸出されて居るる 云ふのは、主に使途は電極方面ではなく、外の方面であら5と思 ひます、日本は便唀な黑鉛の虚地でございますから、最近相禽安

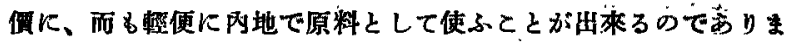
す、從づて諸外國には我がーボン業者が朝鮮から受けて居るゃ らな恩惠を享受して居るのは此䡆的少いのではないかと考られま す。㷋つて外國ではビッチュークスであるとか、或は普通のコー クスであるとか、アンスラサイトであるとか、無晶形の炭素を巳 むを得す使ひまして、えのま小造つたのが炭渠霓極でありまし て、それを黑鉛化したるのが黑鉛化䉓極になって居ります、が

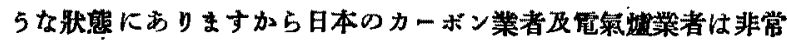
に仕合せをしてて居るのです。割合に㗹良な原料を軖便に手に入れ る事が出來ますから比較的镸良䉓極を安值下製造が出來るのでう yます、促つて日本に造つて居ります普酒䨌極も天然照鉛を原料 といたします關保上外國の炭素管極に比べすと敘程具合が宾し

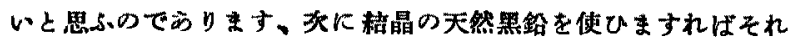
よりは一屡良いるのが出來るのであります。何ほ人造黑鉛になり ま少れば申分のない總ての传良な特性を啃一た理想的琶極になつ

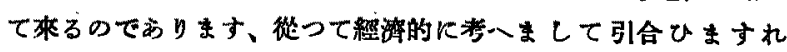
は、人造照颌を使ひますのが分のない枯果になるのですりれど

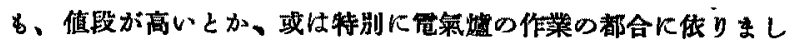

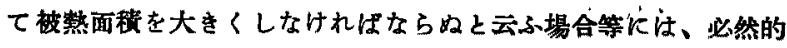

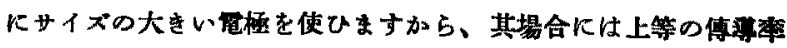
の良い惯極を使ふ必要はない、安い岿極を使つて良いと云ふ場合

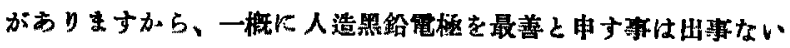
が知れませ妨、是が值段が非常に安くなりますれば、特殊の 
揚合を除いては人浩黑鉛解極を皆使へるゃ5な時期が來ると思ひ ます。何天然黑鉛䉓極ですりますが、是は觮り諸外國にない日本 特有のるのであります、從つて日本の管極を普通の諸外國の炭素 管極に比へますればずつと特性が良いのであります、所調人造黑

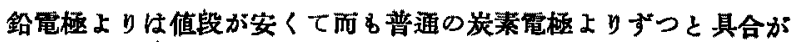

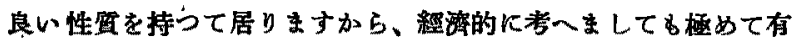
利な埸合が多いのであります、それが篇に日本の電氣整鎆の䘖關 保に於て天然黑鉛電極を推になつて、却つて其方が御有利にな つて居る場合が往なあると思よのであります。八幡の製裁所の野 崎さんの御考案になつた天然黑鉿管極に人造黑鉛のンッブルを附 けまして特に双方の有利な點をコンバインしまして、非常に良好

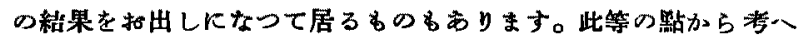
まして外國が炭素電極と人造黑鉛電極の二種頑でらるかか、日本

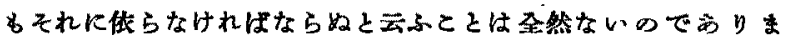
す。現在日本では人造黑鉛電極と天然黑鉛戙極を併用して居りま

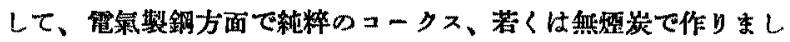

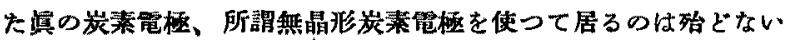
のであります、我かす恐らく㱔造いたして居ら收のであります、 以上の炇第でありますから、どらか日本の國情に传りまして最も 有利なるのを御選定願つた方が宜しい、必ずしる外國の例に依る 必要はない、斯ら考人まして御留考の篇に中上げます。

委貝長(吉川啨十君) 外に御意見ありませぬか。

46 番(川㥓舍恒三君) 只今電極の材質に付きまして、人造黑鉛と天 然黑鉛との比較や何か括話がございるしたが、私は今まで和話の なかつた方面から人造黑鉛の有利な點を一つ逃でたいと思び

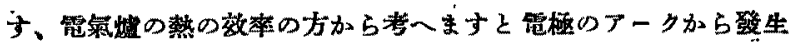

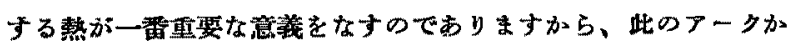
ら發散する熱のエナージ、是と供粭すいき䉓氣のエナージとの割

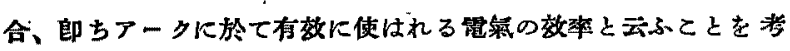

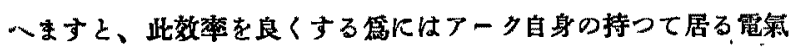

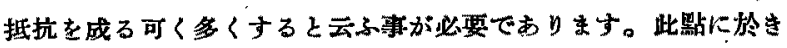
まして人造黑鉛が非常に有利ですります、を申しますのは、アー クのサーキットの霄氣抵抗は、增極の值㣪が大きくなればなる程 アークの長さを長くして初めて同じ抵抗を有するのであります、 然るにアークの艮さ琙限度以上に長くすると、此ナークが非常 に不安定になります、其結果筆流のウエーヴが非常にデフォーム しまして普通のレデスタンス以外にリフクテイヴのレヂスタンス が現はれます。其篇に非常に力率も惡くなりますし、實際運轉上 がら申しましても、アークが不安定であると云ふ上非常に还輠上 不便になります。斯梯な臎でリークレングスを辰くすると云ふ事 には一定の限度があります。そこで電極の直徑の小さいすのを使

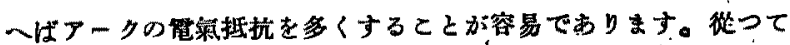
アークから發散するェネルギーの割合を㐱くする、即ち管整の教 率を良くすることが容易になるのです。私は此見地から人造黑鉛 に從來一粠の人が注意してるる以外に非常な有利な點がある事を 申废でて置きたいのであります。

类買長(吉川晴十君) 外に御意見ありませ始か、石川さん、只今の 川崎会さんの拓話に對して何が....

32 番(石川等君) 川崎苦博士心御意見全く同感であります。人造 黑鉛が最上であると云ふ拣は私も先程申上げた雨り、であり寺。

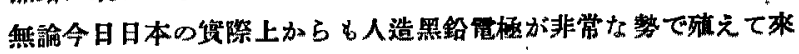
て居ります之は秥晶天然黑鉛上り人造黑鉛の方がフークの生成
及安定が此悛的容易であると云ふ事す考られるーつの理由であり

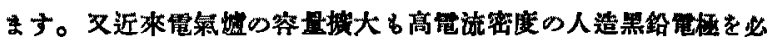
要とする枯果を招來したすのと思はれます。何序に只今の和話の ちりました雱極の成形上の問題に付きして 意し、充分努力して居ります。それで恐らくさ5長い期間を舆、

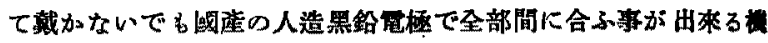

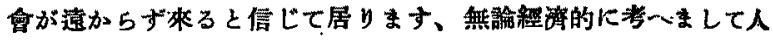
造黑鉛の值段さ一下りますれば、人浩黑鉿に篮一下さつた方が

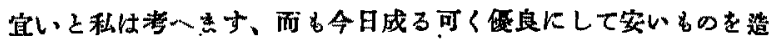
ららとして努力して居る次第であります。

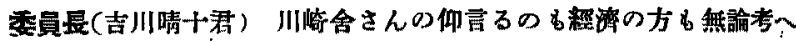
て居らつしやるのでせらが、何が此較でもでざいむせらか、さら 云ふ點があるなら此位末で高くてすまだ有利であると云ふやらな ....

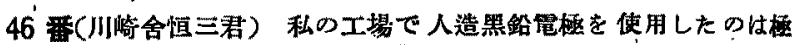
く最近でありまして未だ充分にデーターが揃つて居りませぬ。侐 格を考虑に入れました人造黑鉛と天然黑鉛の經游的方面から見た

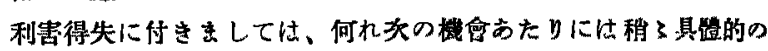

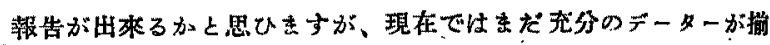
つて居りませぬのです。私が只令申上げましたの徒從來てーク の電峸抵抗さ多くすると云ふ车がアークの效率を良くすると云ふ

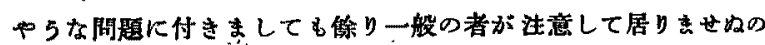
で、其方面加ら見まして人造黑鉛に一つの利盆になる點があると 云ふことを申上げて㫮榢の御注急を喚起した次第であります。

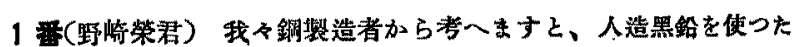
方が一番成絃が良いのであります、所が人造黑鉛忙非常に值段が

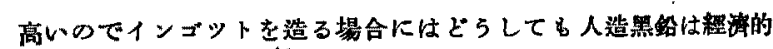
に使一ませ收、特殊鎆の中でも非常に值段の高いすのを造るには

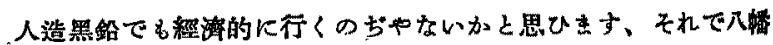

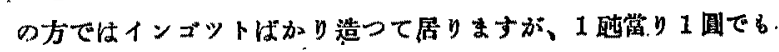
安くしなければ外國のものと到底競争が出來ないと云ふてとを将 八ましたすのですから、学つて人造黑鉛起使つて見末したが、鿎 當りが高く付きむしたので止めて丁ひました、それで我なは充分

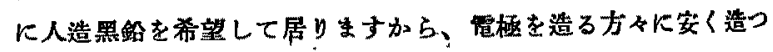
て戴きたいと云ふ希望を持つて居ります、現在は已むを得ず天然

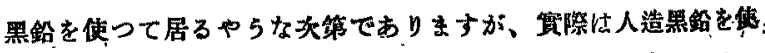
ひたいのですけれど、、悢濟上高く付きまから、現在よりる一 居安〈造つて供給して戴く漛儿御願ひしたいのでありりす。

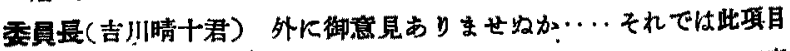

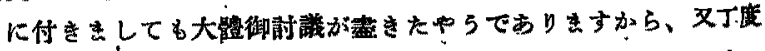
12 時になりりしたから、双で休㥎いたしまして、午後は 1 時か ら始めます。

\section{午後 1 時一再会一}

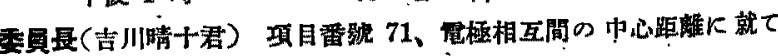

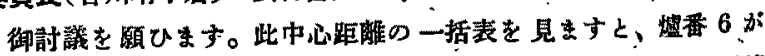

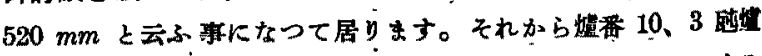
ので、是が $148 \mathrm{~mm}$ 、斯5云ぶやらなのがありますが、さ5する

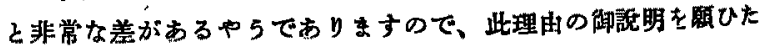
いと思ひすす。

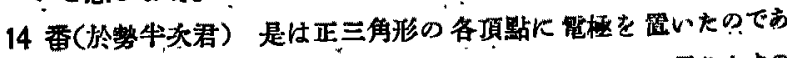

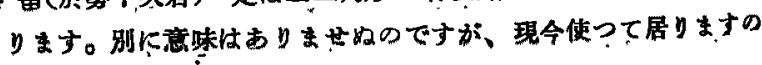




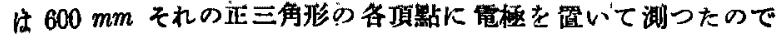

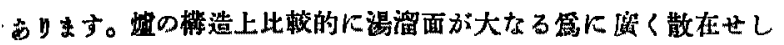
めて居ります。

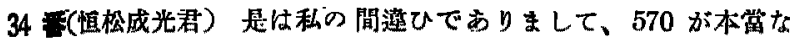

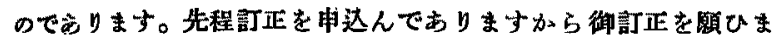
す。

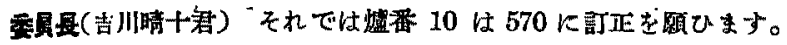
そに就ては前可们山さんから非常に有篮な御講演がありました が、向山さんに御批評を仰ぎたいと思ひますが如何ですります to

49 (间山幹夫君) 私がやりました研究は前に會誌で御筧下ざい ましたやらに、極く限られて條件でやりましたものですから批評 申上げるのはどらかと思ひます。會誌の上でも其點を断つて置き

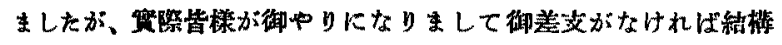
で別にそれ以上の大した意見を持つて居りませぬ。

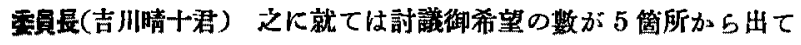
居り末す。相常の御希望があるやらですりますが、外に御意見が ちる方がちりましたら御迅いを酸ひます。

49 要(向山畭夫君) bら一度申上げますが、此電極間の距離は湯溜 の鉷㳯の性貝に依りまして、中の温度がぞら云ふ其合に或時間内 に變化するかと云ふ事と非常に大きな 路保のある問題ですりま

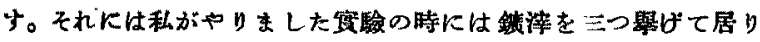
ますが其の租成は略同㩐であります。此のスフッグのコンダク ティヴィティー、流動度其外熱に閶する数字が明らかになればー

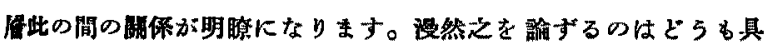
合が惡いと思ひます。それから灭需氣的には三相式三本電極であ

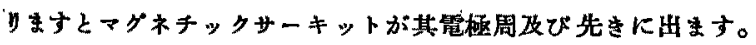
其マグネチックサーキットの强さ及び周派數はボールの䉓流の强 さと周波數に緊保します、若し之等がコンスダントで（同じ霓量 で同し咸保) あつたとしても前の諸關保に相賞大きい關保がある と思います。例一壮其マダネヂックサーキットの出來方に传りま

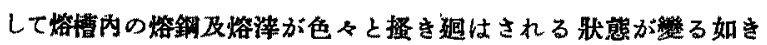
でらります。是は末だ俆り論じられませんが定常作業をなす上に 非常に重大な閶題である己思ひます。簡單には片付けられないわ けです。

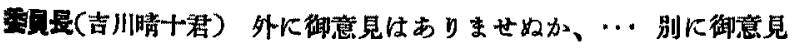

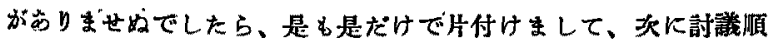
序の 6 番、ずつと飛びまして項目番號 114、裝入の方法でありま す。裴入は大抵人かに依つて居られますが、機峨力に依る゙と云ふ

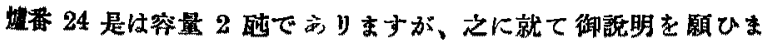
J。

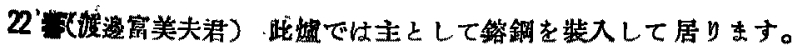

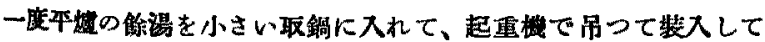

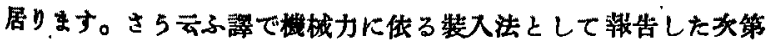
です。冷材绰入の埸合は勿諭人力でやつて居ります。

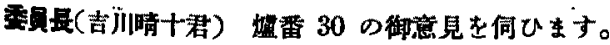

21 春(中村道方君) 私の方はシュートを使つて居ります。それを 唯䉓力で持上げて、さうして嘘を傾けてスローブを㮵一てスれて 居る慗です。

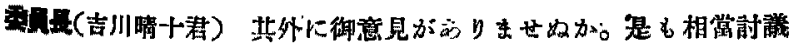

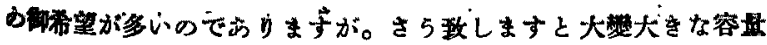

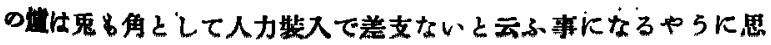

ひますが、それで宜しらどざいますか。

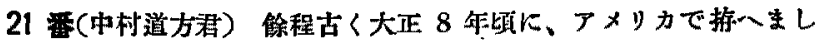
たのは、丁度平爐と同じ装入機を使つてやつて居つたのを見たの でありますが、何處加皆栐の方であ〉云ふ種類の特入機を使はれ てやられて居る所がありましたならば、それを御同ひしたいので す。無論容最は 10 䣩以上位の可成り日本で言一ば夫きい方の椬 の部類に㰾して居るものでありますが…。

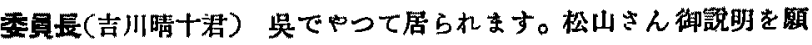
ひす。

27 番(松山筧慈涒) 御望問の大きい烣で目下試駿中でありますが、 それは本嘴と同じやらに機械力でやって居ります。

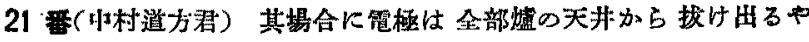

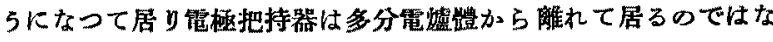
いかと思ひますか、それはどら云ふやらになつて居りますか。

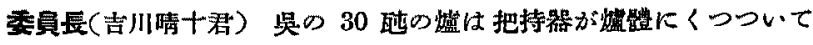
居るのであります。笔極はすつかり上げてしまはずに、装入函が 引掛らないゃらな程度に上げて固いて裝入するのです。

21 番(中村道方群) 私も離さずしてくつつけたいと思ふのであり ます。さ5すると大分電氮的に电都合が好いてとがあると思ひま

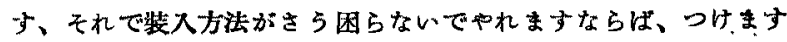

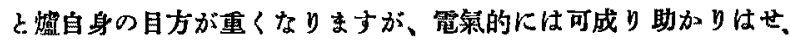
外と思つて居ります。是は 20 䣩以上位の嘘の場合です。

委員長(吉川晴十君) それはつけて镇いても别に對支ないと思ひま 士。

21 番(中村道方君) 唯共䉓極を捲上げる高さでございます。此問 題さ一解決されて來れば宜いと思ひます。それから辋入物が落ち る時のショックが管極に及んで來ると云ふやらなととはないでせ

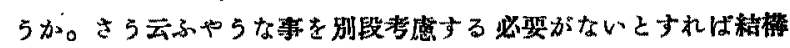
です。

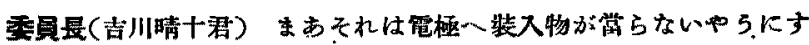
れば、ぐットに落ちたショック位は影響しませ好と思ひます。

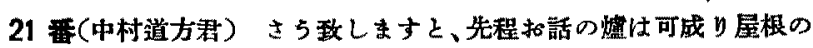
高さを高くしなりればならねと云ふ事になりますね。

程員長(吉川晴十君)さらです。

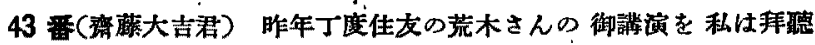

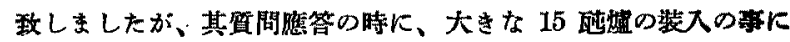
付ての筫問に對して御答があつたのでありますか、其時に 15 能

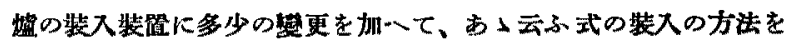
基にして御使ひになつてるると云ふととを御答になつてるるので ありますが、其後既に御使ひになつて居りませ5か。其梾子はむ ら御分りで晾りませらか。

11 番(荒木柣㜍) 只今の御話で御座いますが、1 㔻のチャージン グタレーンを铅計政しまして漸く出來上りまして、今其試荤轉中 です。其結果はまだはつきりして居りませんが大體に於て好成耤

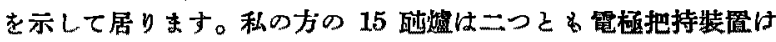
蛙體にひつついて居ります。さらして電極は天井の下の面すれま゙ れまで上がります。それですから裝入機でやつて蟹極に打ち當て ると云ふことは有りませ。最心配して居りましたのは、令まで シュートを使ひました成綪が職工が段々惯れて参りました結亲、 割合に好い具合にり末年ので、チャーデングクレーンを使つて それ以上の成嚗が出來るが゚らか、それを稍疑つて居りました

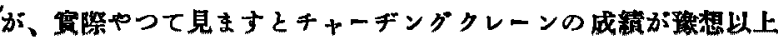


に好かつたので、大いに安心して居る头第であります。然しまだ 之に期聯したスクラップヤードが完成して居りませんためにチ十

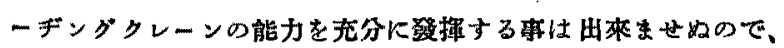

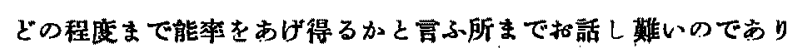
ますが大體の見赏を申上げますとシュートを用ひて居つた時の牛 分位の時間で裝入するととが出爽るであららと考一て居ります。

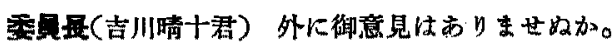

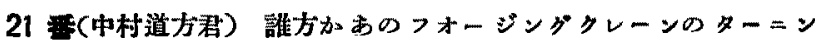
グギャ一のやらなるの要領で裝入されて居られる御力がござい ませ好でせらか。詰りチャーギングクレーンを趣轉される摆です 加。

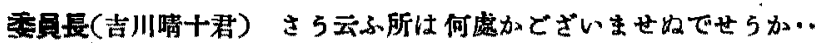

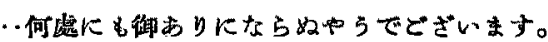

21 蹗(中村道方君) 是は唯自分のアイデアとしてぐありますが、何

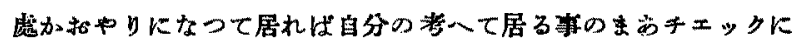

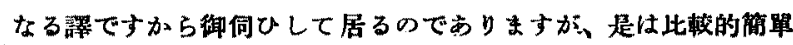
に行くのではないかと恕って居るのであります。私の方では现在 は先䘞申上げました様にシュートばかり使つて居るのでありま ナ。併しど5 此前の時にも色々拓話支何ひましたやらに、シュ

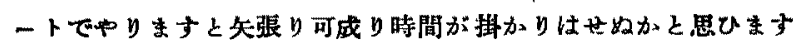
しヌこちらの钦しい所に落ち得ないのではないかと考人て居りま す。特にフォーヂングなんかをやつて居る所では大きなスクラッ ブを徒入政しますと、どらす妙な所に落ちたら動かすに骨が折れ 自然裝入に非常に時間が撕りますので、知張り欲しいと思つてろ ろ所に落るゃらにするのが必要ではないかと思ひます。特に芘入 された原料のコンダクテイヴィティーの䦗题すりますからニ= フォームチャーヂングが是非必要であるる思びす。

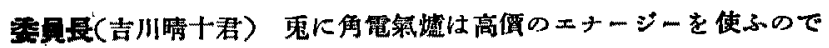
ありますからしして、成るくく裝入の時間等は短加くすると云ふ事 が必要ででざいませ5。烧の容量が大きくなりまする、どらして， 它機械力に依らなければならないと思ひます。機械力とすると少

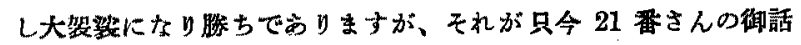

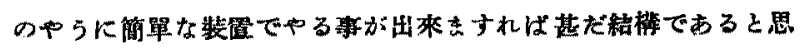
ひます、之に就て何か御意見がありますならば御逃でを留びいい 々思ひます‥6らとざいませ好ですか。それでは此問道は是だ

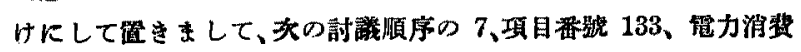

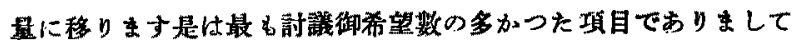

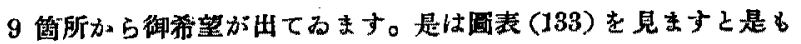

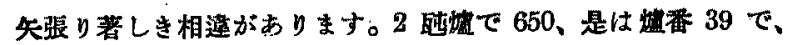
それから 850 と云ふのがあります、是は㣰 38 。それから 777 と云ふのがありりす、それは螅番 35 でそれから 900 と云ふのが 植番 5 であまりす。们此嘘に對しては更に之を 830 から 900 之 云ふ風に御訂正になって居りますから多少減りましたのです。之

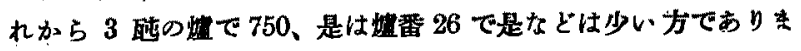
す。是等の御說明が原一れば秙槛と思ひます。先つ俎番 39 の御 方に醋ひます。

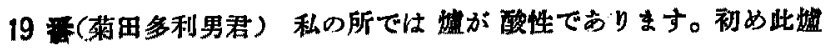

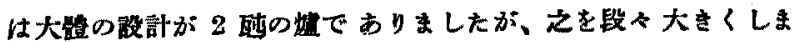

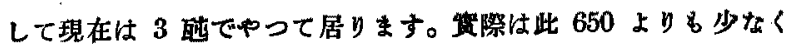
600 位で出來る場合るあり末す。外の植上りる大分少いのです

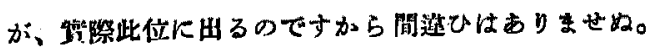

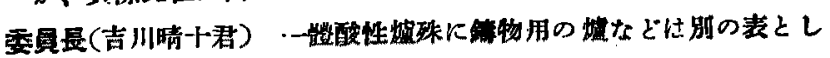

て揭げなりればせら收のですが、今四は明に政さながったのであ yょ。

19 番(菊田多利男君) 大䯠初めはインゴットに使つて 居つたので らりますが、それから段々鏡銅をやりましたいのですから酸性の 方を使つて居ります。それは矢张 750 位であります。

委貝脣(吉川晴十君) 赤物ですか。

19 番(葋田多利男君) さ5です。

添是長(吉川晴十君) 嘘番 38 は如何です。

34 番(恒松成光君) 此 38 の惯は艮方形型のナショナル式のいので して、嘘が非常に小さいのですから燃解する材料を一タ約 5 哳か

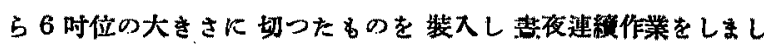
て、4 四乃至 5 回焀解して居ります。さらして鏡銅に用ひて居り

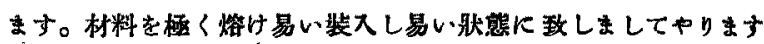
钢保で、是は其時に調查致しました約 2〜3 篦月の本均でありま すが、筑際此通りに行つてるるのです。基性でやって居りま す。

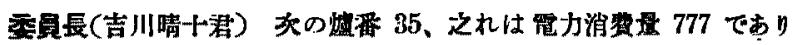

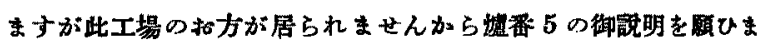
す。是は 900 でしたが、更に下がつて柬て、830から 900 と云 ふ事になつて居ります。

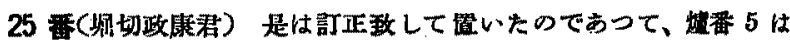

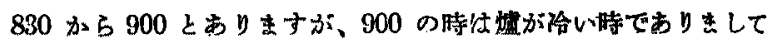
それがら後で崸を㳑めて 2 回以後が 890、それで始終本均して此 程度でやって居るのであります。

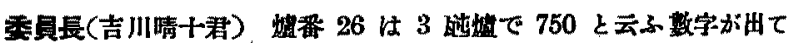
をりまず・..。

4 蹗(青木元㨁君) 是は殆ど私の方では特殊銅なやりませ々ので普 通簿物ばかりをやつて居ります。それと材料極く良いるのばか

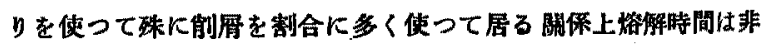

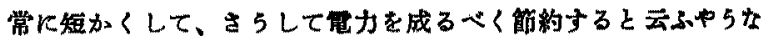
方針からさ5云ふ風极數が出て来たるのであります。

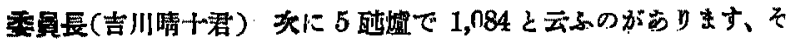
れは熆 30 です。

21 番(中村道方君) 私の方は初めから 700 が 750 位になつて居 - y寺方。

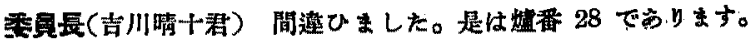

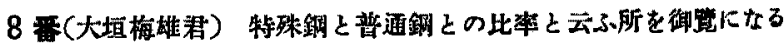

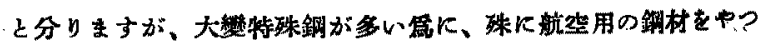

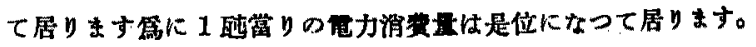

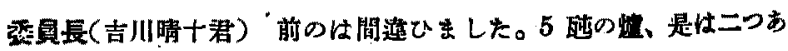

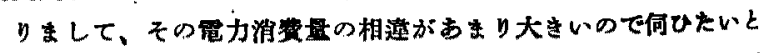
思つたのです。只今の御顶明で一方が特殊銅でありまして蟠 30

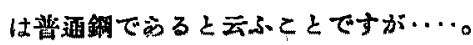

21 蝶(村道方君) 春通鋮の方が多いのであります。 委貝長(吉川晴十君) 嘘番 30 が今度 750 に訶正されたのです。 21 番(中村道方君) それは 50 位の彎動は䊉えず起り得るのであ

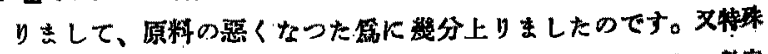

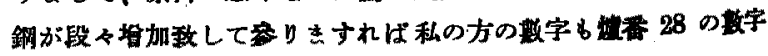

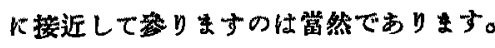

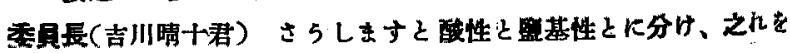
镜物とインゴットをに分け、更に普通銅上特珠銅とに分けますと、

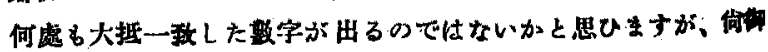


意見がまりましたら御逝心゙を酮ひます。

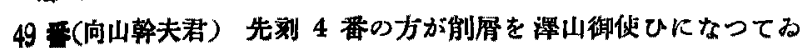
ると仰しやいましたが、㓩展大゙けでとざいますか。

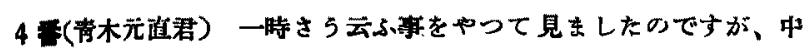

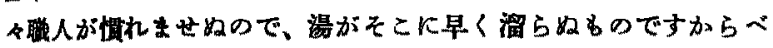

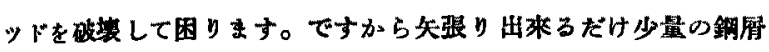
で以つて、使用霄力量を減らして居ります。

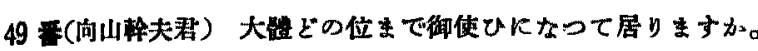

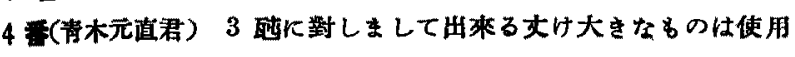
世す銅厥 500 から $700 \mathrm{~kg}$ の程度ででざいます。

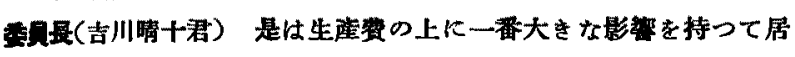
るいつでありますから、色々討僮御希望數す澤山ありましたが、 倨色御意見があるだららと思ひますからどらか扰述でを願ひま 才。

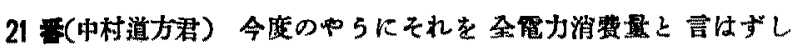
て、今度御示しになりましたやらに㻌解䉓力、それから仕上げ笔 カと云ふ風に 2 つに分けて 御討議を願ひたいるのででざいます が如何ですか。

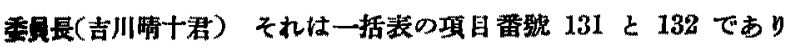

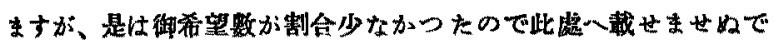

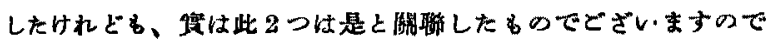

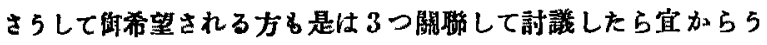
と云々梆缺思であつたと思ふのであります。それで 21 番さんの

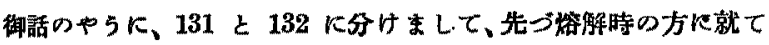

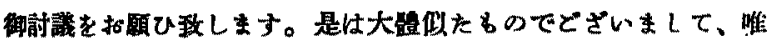
5 啮の所が2つ暹ひますが、是は大體先程の御顶明で分つたかと

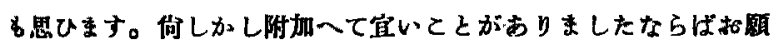
ひします。

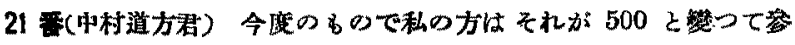
り生した。大锖其造になりす。今度美上げました耀告の方には さら訂正して置きした。

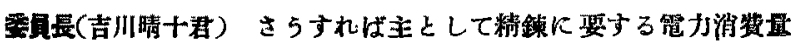
の连ひになるのででざいますか。

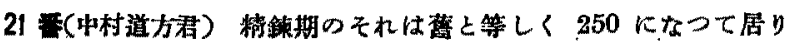
\%。

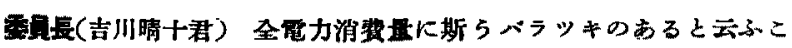

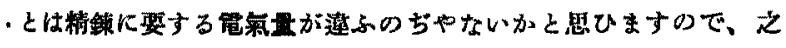

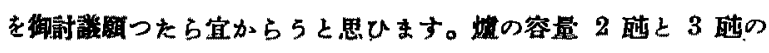

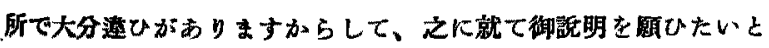

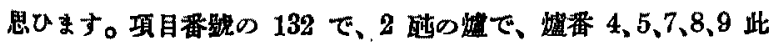
吰です。嬏 4 では 530 であります。

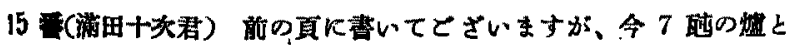

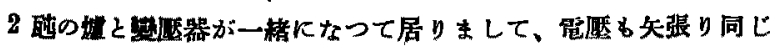
や5Кなつて居ります。それで少し無理なので、さら云ふ值が出

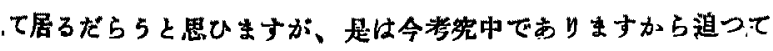

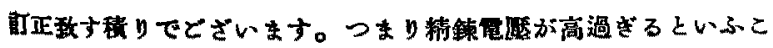
をは一特的に熟が上り過ざ一方には天非を施したりして加诚をす

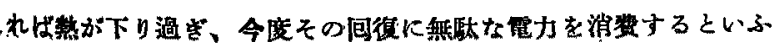

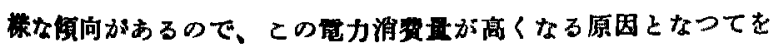

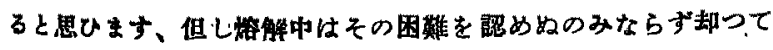
㭙闲は早いのであります。

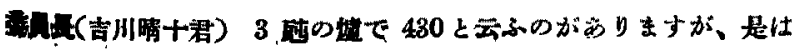

蟠 10 です、之れイついて何が燔意見がずり去したならば同ひ そいと思ひます。

34 要(恒松成北君) 實は此 3 酺と云ふのは先程も申上げましたの ですが、宽際は2醚と言つた方が宜いのでありますから、2 通に

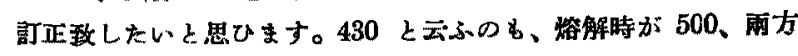
で唯時間の關保で斯5云ふ風な㓶合にして居るのであります。

焉共長(吉川晴十君) 外に衔意見がありましたら原します。

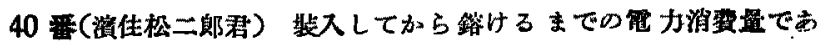

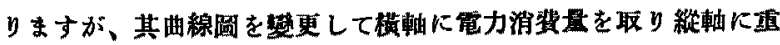
裸回数を取つて一つの公算率曲線盛を作ります。さらしてマキシ

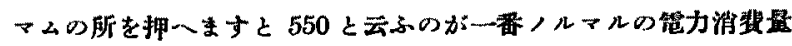
と云ふ事になります。其決め方で最む碓かな教が决まるや5反思 ひますが夫で如何でせら。

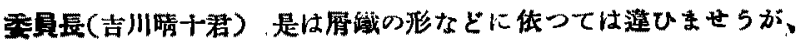

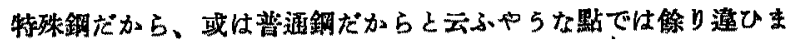
せマ20ですからして、大體是は一致しなければなら奴ことつ思ひ ま。只今 40 番の㼡話のや5に此位の所が普通で、それから違 つた稌り離れた所は何處加りり方に堂ふ所があるのぢやなから かと云ぶらなととが分るのだららと思ひます。外何か御意見 はありませ如。

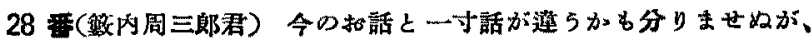
先程削屑を澤山使ふと云ふ御話がありましたのですが、其場合に

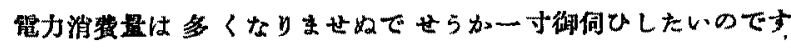
が。それは私同じやラな屑践とを使しまして、其配合量を色な 一てやって見た所が削屏の 1 割位まで消費量が少し上がつて來ま す。それから 4 割から5 割位の所では下がつて來ますがそれ

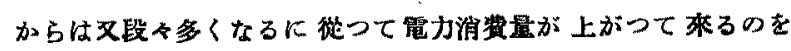
經驗したのであります。それで一寸伺ひたいと思ふのですりり 广。

4 要(青末元淔君) それは私の方ではさ5云ふ事はありませ如。そ こで剈層ばかりでやつて見ると、それは先副中上げましたやらに

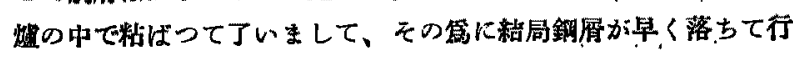
がいと云ふ事がありまして、それで時間が長く期るととああり ます。私の方でやりましたのは割合に大きなるのを入れると、矢

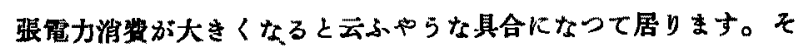

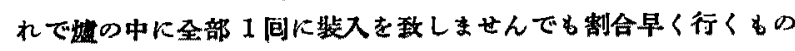
であると私恃思つて居り杰す。

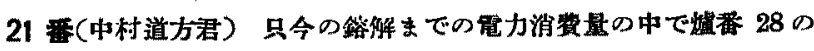

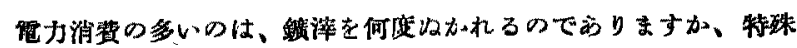

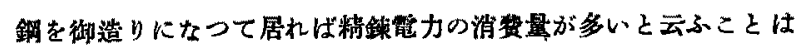

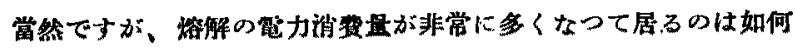
なる理由でせらか酸性锖漳 2 度にでも造られて居られるのです is

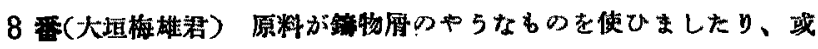

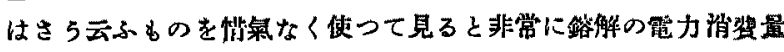

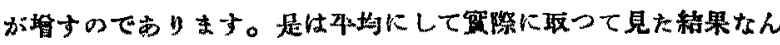

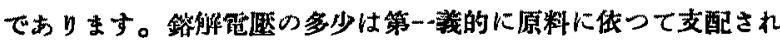
ると申して良いかと思ひます。

至是畏(吉川啨十君) 其外に御意見はございませかか。

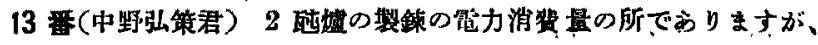
其處の一番下に $250 k w$ と云ふのがあります。それ恓分私の方

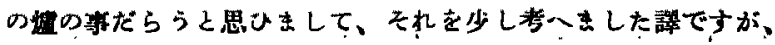


是は此荫名古尾で研究部會がありました時分に、神谷さんの御亚 演で隐分其時に考人たことなんですが、ど 5 る其筑力が $250 \mathrm{kw}$ と 云ふてとでありますと少じ少いやらでありますが、それは䊑鍊眝 間が少なかつたのであらうと云ふ事を其時がら考人た譯であり゙ま す。所で其後段々精鋪時開を長くしまして、さ5して其結果今て は時間が大分延びて居りす。從つて電力が晢して居りますが、 今度訂正をする所までまだ確信がなかつたものですから、产衣用

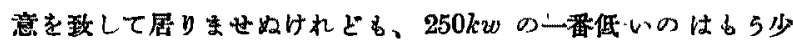
し上一上がるだららと思ひます。其一番下のやつはす5少し上で それが 300 以上になりさらに思むすすからてれを訂正して置きま

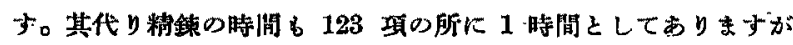
是が 1 時閒牛以上今撒ることになつて居り末すから、彼此 2 時

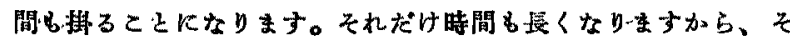
れだけ䉓汃消費量る從つで多くなるだららと思ひます。

要員长(吉川晴十君) 其外に御意見はまりませ如。

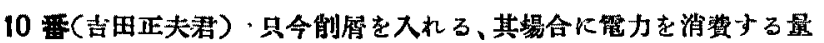
がどら云ふ風に戀るかと云ふととを御研究になつたさらでありり

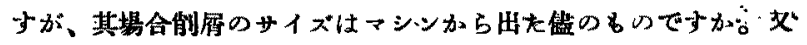
シャーか何かで小さく切つて居りますか。

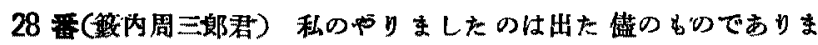

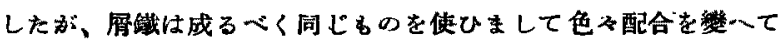
やつて見たのであります。

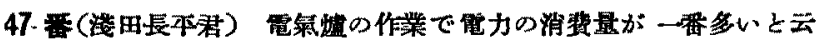

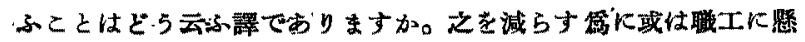
賞をつ林るてか、何とがら云ふ事をやって居られる所はござい ませ姑せ5か。詰り賞與を出してやるのです。一般の人は 600

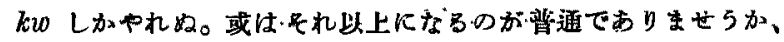
若しそれ以下になれば、それは職工脃衣依るのですがら、さ5 云ふ場合に何か賞與を出すと云小中5なととを中つて居る所はあ りませぬでせちかか。

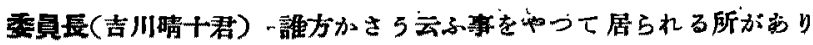

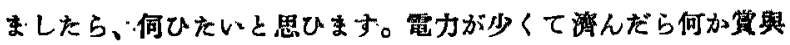

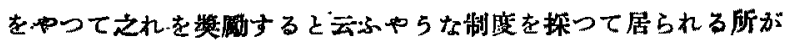
ありますか。

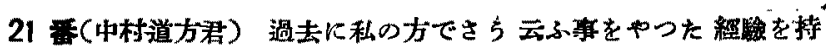
つで居ります。併し其結果は觖り面白くなかつたので琴在では止 めて居ります。ど5も私の方のやらに、色ぬのダァラィティーの 多いるのを造りますと、どらしてる技所が職工を監督すると云ふ

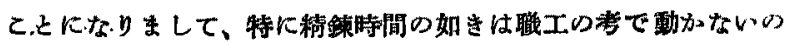

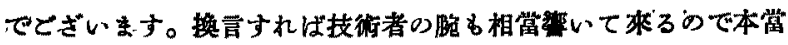

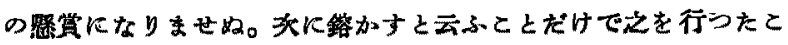

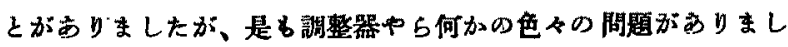
て矢張り篹り好い結果は表はれませんでした。䊅局でんざいにな

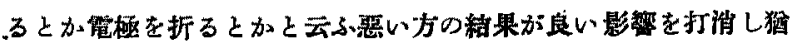
俆りありといふ結果になり現在では止めて居ります。

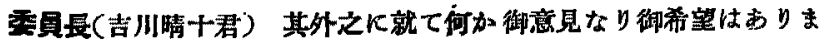
世加。

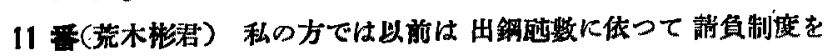
つつて居りましたが、其絡果は矢张面白く岁りませんでしたど5

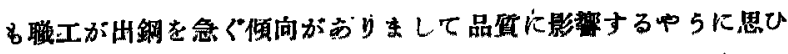
ます。それで最近は此めして、今度の町正にも出して面さまし たが、最近では需力消翼量が逆に多くなつて居ります。其理由は
早く晹を出すと云ふ上りる品質本位で作業せ上と云ふ事下根本方

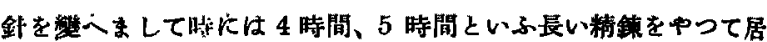

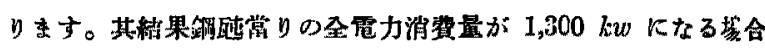

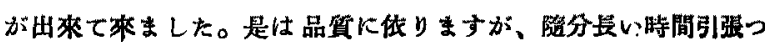

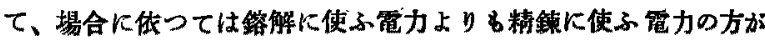
多くなつて屈ります。それで此精鉬に要する電力と云ふすのは特

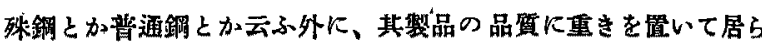

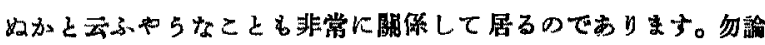

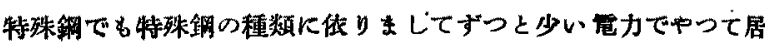

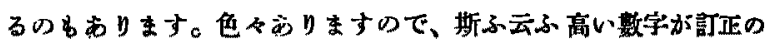
方炕出て居りますから、それだけ申上げて管きす。

委員长(吉川嘀十君) 只今の 900 とりりしたのが 900 至乃 1,300 と云ふ高い数字です奴。

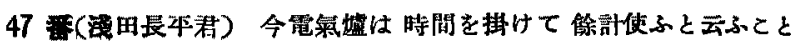

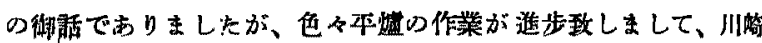

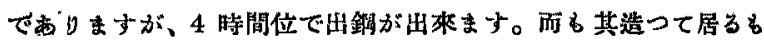

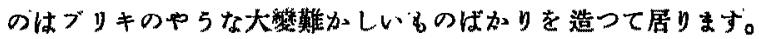

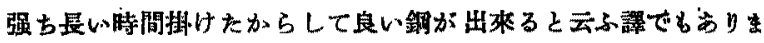

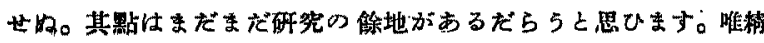
镇時閐走保計教けたがら良い鋼が出來ると云ふことは言へないだ ら5と思ひす。短時間で外に何加良い方法がないるのでせ5 か。若しありましたらそれを何ひます。

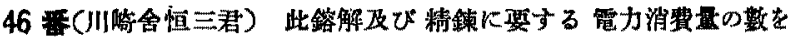

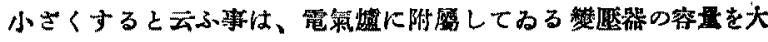
きく致しまして、鉻解期に於ウる電力の供給を多く政しますと、

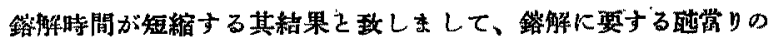

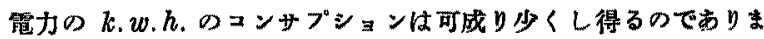

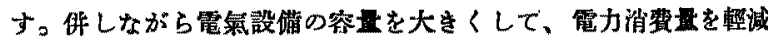

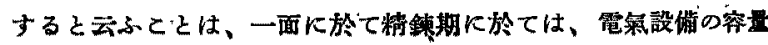

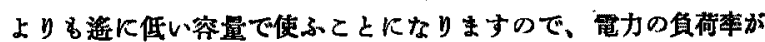

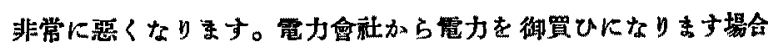

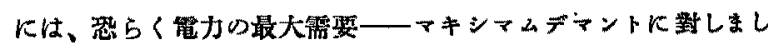
て普通ミニマム、チャージ訪課せられるのであります。そてで䉓 力の角荷率を瑟くすると云ふことは此のミニマムチャージに洋す る篦力を使ひ得ないと云ふて上があるのであります、唯一概に酗

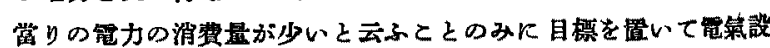
储の管量を論ずると云ふてとは如何かと思ひます。るつと譜しく 申しますと、マキシアムデマンド侤る暗力チ+ージと、キロワ

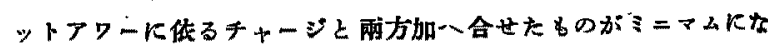
るやらに攀然器等のキャバシティーを決定するととが一番合理的 な方法であら5と思ひ方す。

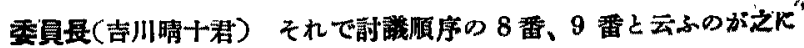
眑第するととでどざいますが、只今川崎合さんから御話がありま して、何資料を御持ち下さいましたからして、同時に之を討辣し て頂いた方が都合が好いかと存じますが、如何ででざいませら 加。'

46 番(川崎舎恒三君) 只今の御話を政して至交ないと思ひます。 夌而昷(吉川啨十君) それでは先ゔ 133 番を片づけてからさら云子 事に秋しませ5。

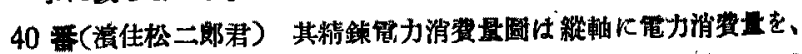

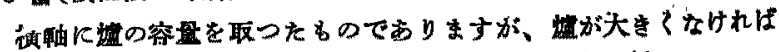
地力消数量が減るだららと云ふので、さ5云ふ佷想的曲線を引が 


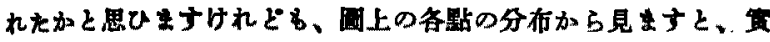

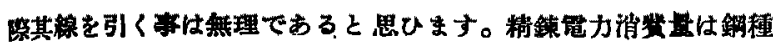

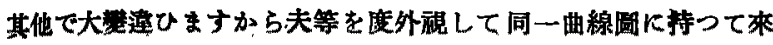

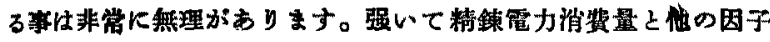

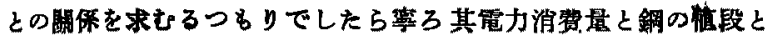
の閵保を取る方が却つて何等か规則的な曲線になりはしないかと 思ふのであります。之等の點に就て何为御考入を願ひ度いと㙰ひ ま。

香只長(吉川晴十君) 御尤な御意見でどざいますけれどむ、さら云

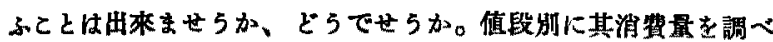

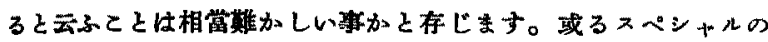
あのК對してやりましたならば出來妨ととるないかる知れませた が、是仙何れ宿题と致しまして後でやつたら如何でせ5か。それ では是は皆样の方で後日研究して頂くこと〉致します。外に何か 御澺見がありましたらどらぞ原ひます。

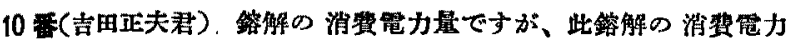

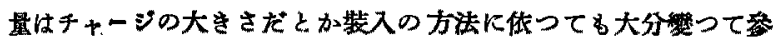
るだら5と思ひますが、此裝入方法ででざいますが、私の方で㤌 從來孔埋めよ云ふやつをやりまして、ポーキングをゅると云ふと とは全然施行して居ないのであります。此てとに閶しましては一

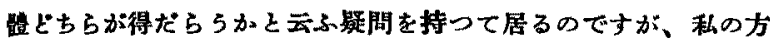
の工場のデーターでは此孔埋めと云ふ式で行つを方が笔策の使用

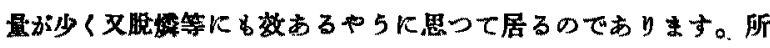

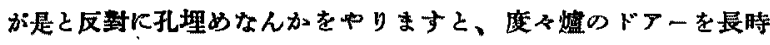
間開けますので爈內が冾却され、從つて電氣が漯山要ると云心風 なととが一般に䇾はれて居るのでどざいますが、筫際には孔埋め

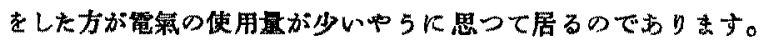
之K付きまして孔埋めをするに就てはどらしてる小さいスクラッ

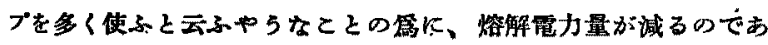
る事いかとる思つて居るのですが、如何ですか。

秦員是(吉川晴十君) さ5云ふととを外に何か御研究なさつた方が ありましたら御逝一゙を原ひます。

34 鲨(恒松成光君) 今孔埋以の御話がありましたが、私の方でれ 埋めをゃって見たてとがあります。併し現在は矢張りチャージを

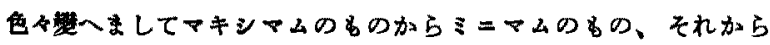
極く料加いるのを崔に入れられるだけ一杯裝入して、それに依つ

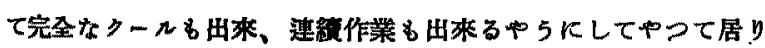
まして、さ5して裝入は 1 国乃至 2 回位にして居るのでありま す。それで其方が却つて短樎出來るのではないかと思ひます。ど 5品埋めをやつて居ると色ななトラヴルを起しまして、其時に 量枚を折つたり政しますから令では此めて居ります。

香是是(吉川晴十君) 外火御意見仕御座いませ始か。色な有湓な御

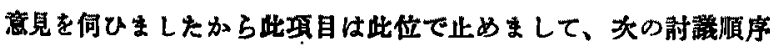

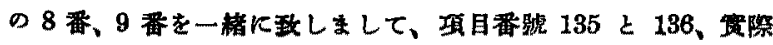

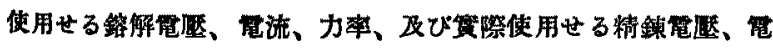
流、力率ででざいますが 午前中に一寸御話のありました焜番 16 で、180vを $100 v$ に訂正された理由を御炋明願つたら参考にな りはせ放と思ひますが如何ですか。

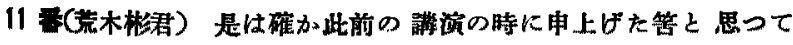

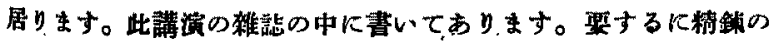

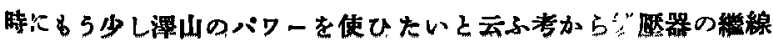
をすっかり戀てしまいました。それで初めから終りまで.100、

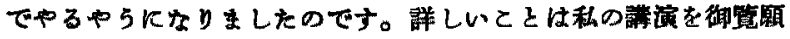
ひす。

委員長(吉川晴十君) それから蟠 30 では $7,000 a$ を今度は

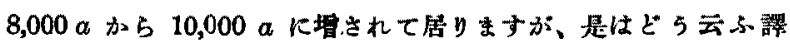
ですか。

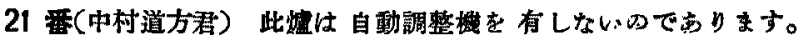

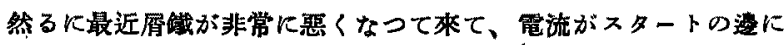
可成り强く卦つて來る譯であります。それから原料が惡くなって 來ますと、大體大きいるの学入れた閒に細かいるのを入れると云

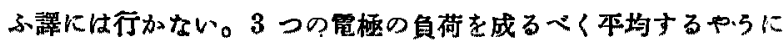
やつて居るのが、原料の具合の瑟い学に可成りの不本均が出來て 來るしエナージコンサンブションが惡くなつて來る便きがありま

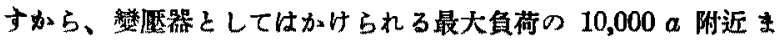

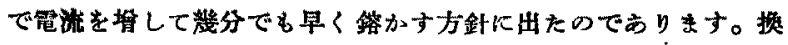
言すれば愿料の良い場舍は調整が5まく行きましたものが段冬5

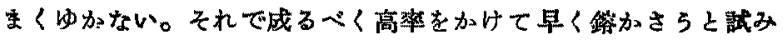
て居るのであります。

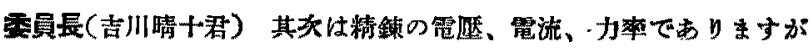
蠉潘 17 方前间 $130 v$ とありして、それをむら少し低くした いがどらも出來ないと云ふやらな御炋明があコたやらに記憶して

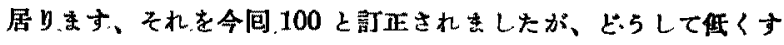
ることが出來ましたのでありませらか。

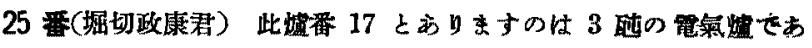
ります。是は宾は私のカでは、四阪島精錬所で使用する目的で特 に造つた電氮嘘です。それは御存じの如く四阪島々新居演とは廿 イクルが遼ふのであります。其サイタルの違ふるのをとつち一持 つて来まして、四阪島から新居溜に移轉政しましたすのですから

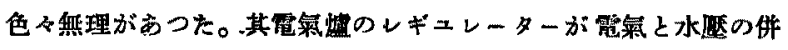
用になつて居りまして、其水に監分が合杰れると云ふてを仙非常

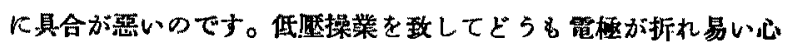

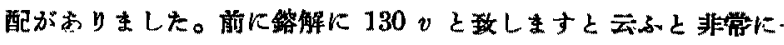

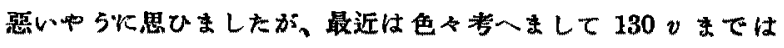
行けるやらであります。，更に極最近では水を戀いして、100v で操業して居ります。斯5云ふ風な程度のものであります。

委買长(吉川晴十君) 此 2 项目几就て川崎舍さんかから、括しがある と云ふととでどざいますから、之を令何つでれから外の方の赦 意見を伺ひます。

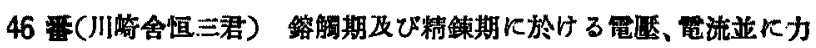
率の問題でありますが、前回御提出願ひましたデータに㑈りまし て色々維計を取つて見ましたのでありますが、不幸にして繶計的 に合理的な曲線を見出すととは出來なかつたのであります。それ

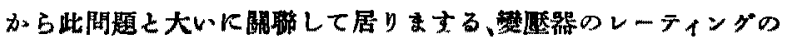
定格容量です。此定格火依つて定められて居る鎮解期及び精鍊期 の管医、電流是る曲線にして見ましたが、えを見ますと如何に此管 医、管流の關保が不合理的に使用せられて居るかと云ふととが制

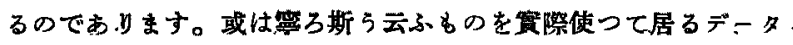

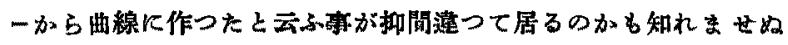

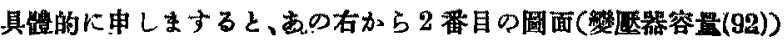

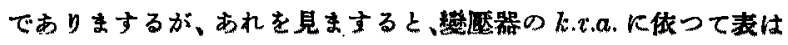

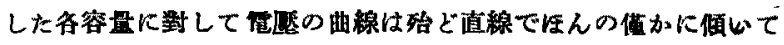

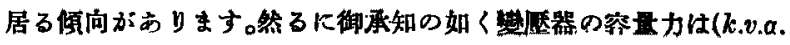

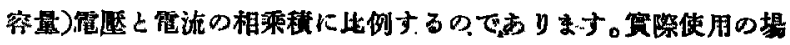




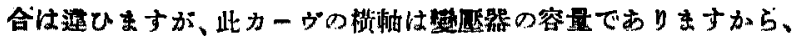

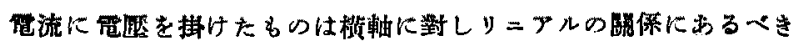
管で市ります。然るにあの曲線の各容量に付て霄流及び管魇を取 りましてこれを掛合して圖に書いて見ましてもリニアルになり せ奴、是は個くの電丝及電流の平均值を取つたのでありますが、

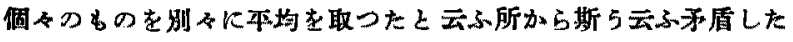

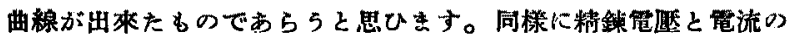

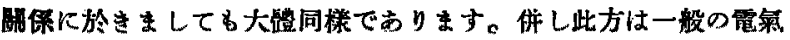

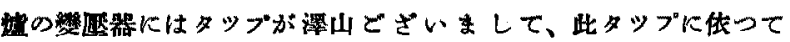

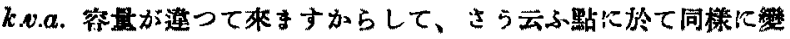

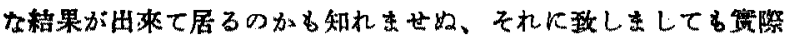

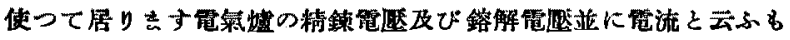
のが或る一定の规律に传つて支配せられて居ら虹と云ふ中らな感

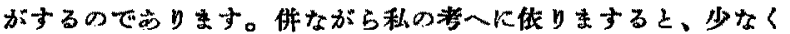

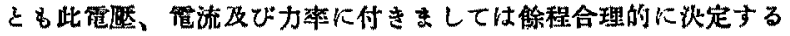
手段がある之考以るのでありむす。それに扵きして私の所見を

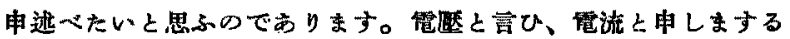
が要するに霄氣嘘に供給すべき熱のエホルギーが基本になるので 的りまして其熱力率け先新他の問題で申上げました如く、管氮の

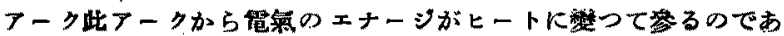
りまして、フークに依つて發生する熱が基本になるのであります。

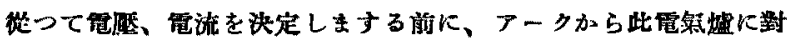
七ては何 $k w h$.の霄力が熱になって發生すべきであるかる云ふて とが先づ㹟定さるできであります。此决定方法に付きましては多

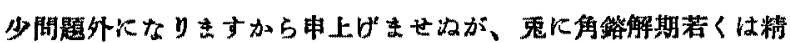

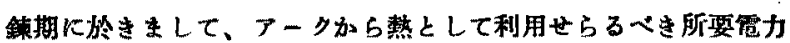
が决つたと侵定致します上、そこで次に起つて來る開題はアーク

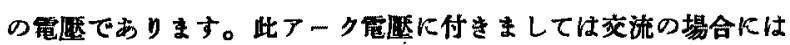
大きな䉓極に付ての蕒睑はないのでありますが、極く小さな電極

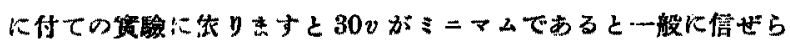
れて居ります。是はミセス・エヤトン及びスタインメッッ先生其 他アメリカのノッチンガム氏、斯ら云つた人々の研犯の絬果が大 體一敌して居ります。先ゔ交流の場合に $30 v$ と云ふととがアトモ スフイヤが清潔ですると云ふ場合のミニマム・ヴオルテージと考

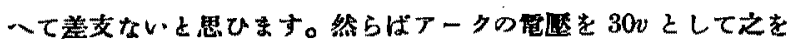
ミニマムに政しまして幾らに決めるかと云ふ間題でありますが、

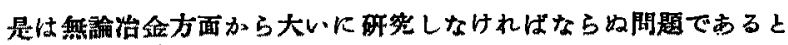
思ひす。不幸にして今日其方面のことは餘り明睹になつて居り

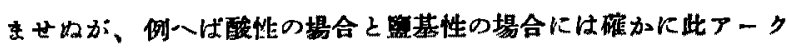

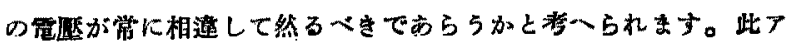

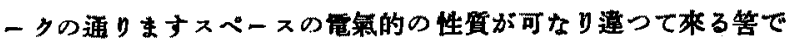

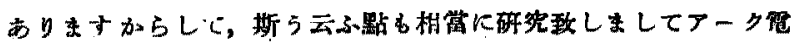

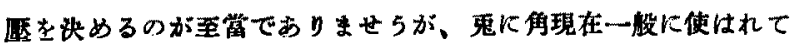
居ります基性の蛙に於きましては之を50v上りる一寸上に取つ てみるのが多いやらであります。是が最大值に付きしてはス加 に限度がありませ5が、鬼に角アーク暨廆を50v 以上或は $60 v$ と云ふ風に取つてるるのが多いやらでありりす。斯橎に政しまし て治全方面のことる出來るならば考虑に入れましてアーク等を

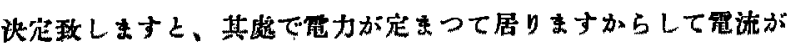

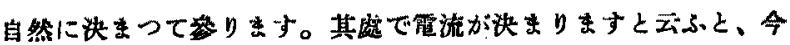

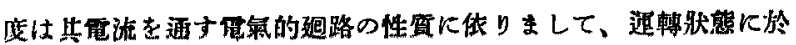
きむする力率、郎ちパワー・ファタターに影して率るのであり

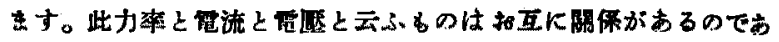

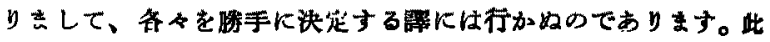
力率を如何にすへきかる云ふ開題は理想を申しまする之、成るへ く力來を良くすると云ふととが理想でありますが、餎り力事を息 くしますと西極使用中にアークが短耛する、声りシャウトサーキ ツトした場合に規定の笔流に比して非常に大きな䉓流が流れるる 云ふ不都合が生じます。之に付きむしては䃌力會社方面に於きま してる短絡電流の規定霓流侍する倍率と云ふらのを非常に重要 視して居るのでありまして、此問題を等䦥に付する镬には行かタ のであります。加本の決定如何に倲りまして電氣嘘の弧光とし

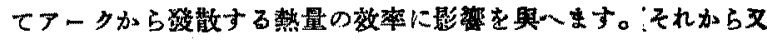

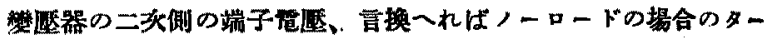

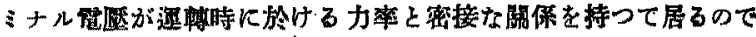
あります。是等の關保俚或る僅かのフッサンプション、即方笔䒺

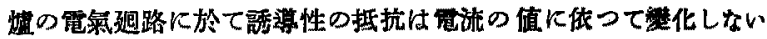

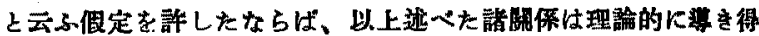

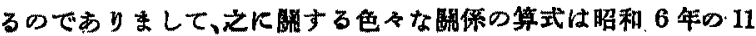

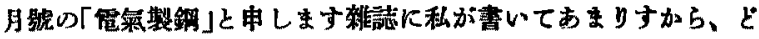

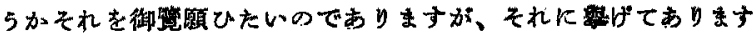

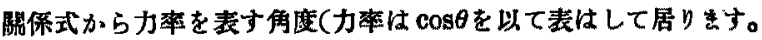

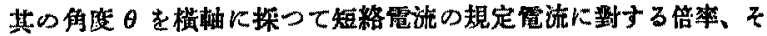

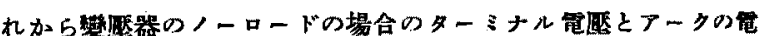

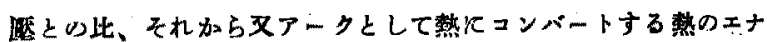

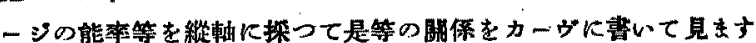
と、此處にあり末すやらな圆表が得られるのであります。宠等の

A 圆

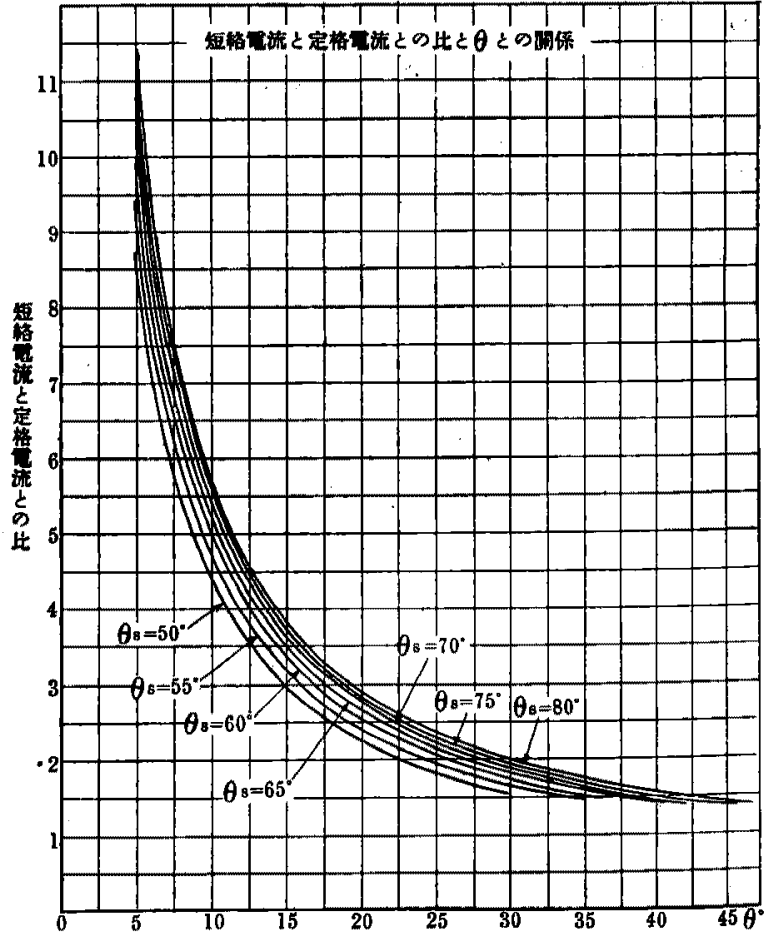

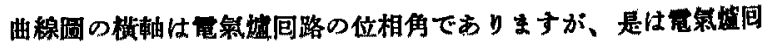

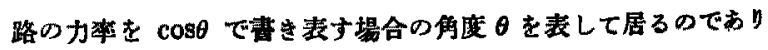
ます。A圆はアークを短絡した場合に起る军流の规定䉓流に到

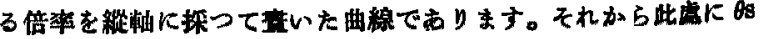


と萧しててありますか、是は短絡位相角と申して居ります。是仕ど

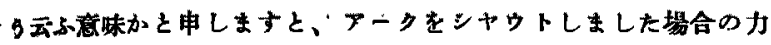

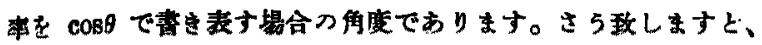

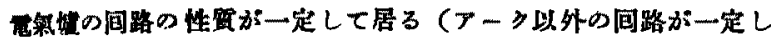

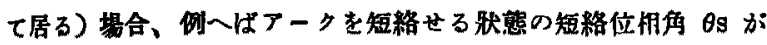

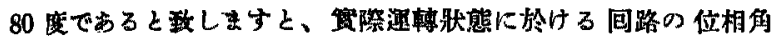
を段な敛人で考入て見ますと、位相角 $\theta$ が小さい場合に此カーヴ

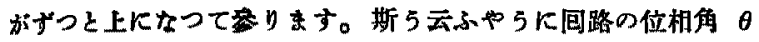
が小さい場合、寻换一れば全囫路の力来が非常に宜い場合には短

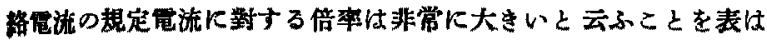
して居るのであります。段々此横軸の角度を增してでりし、

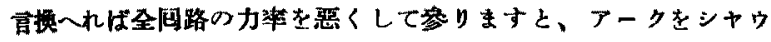

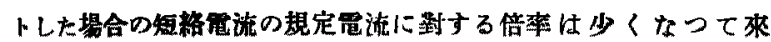

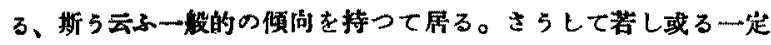

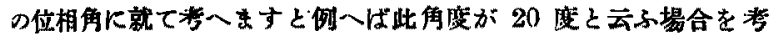

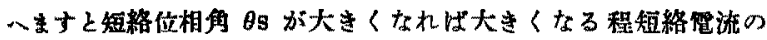
规定䉓流に䍌する倍率は增して来るのであります。此カーヴは上 の方が $\theta \mathrm{B}=80$ К相常するもので段々下に行く程此角庭が少さく

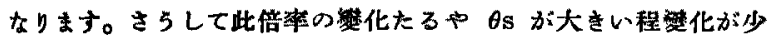

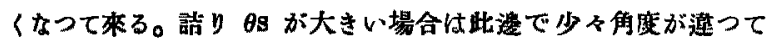

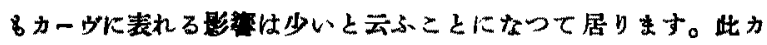

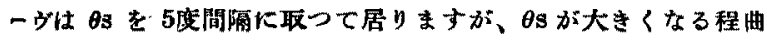
檄の間隔が小さくなつて居り末す。是が至国路の力率位相角之短

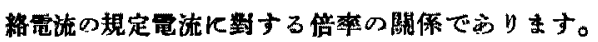

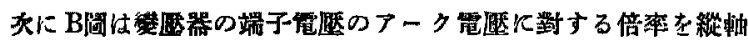

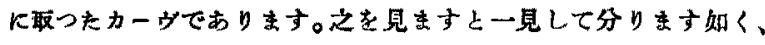

B

固

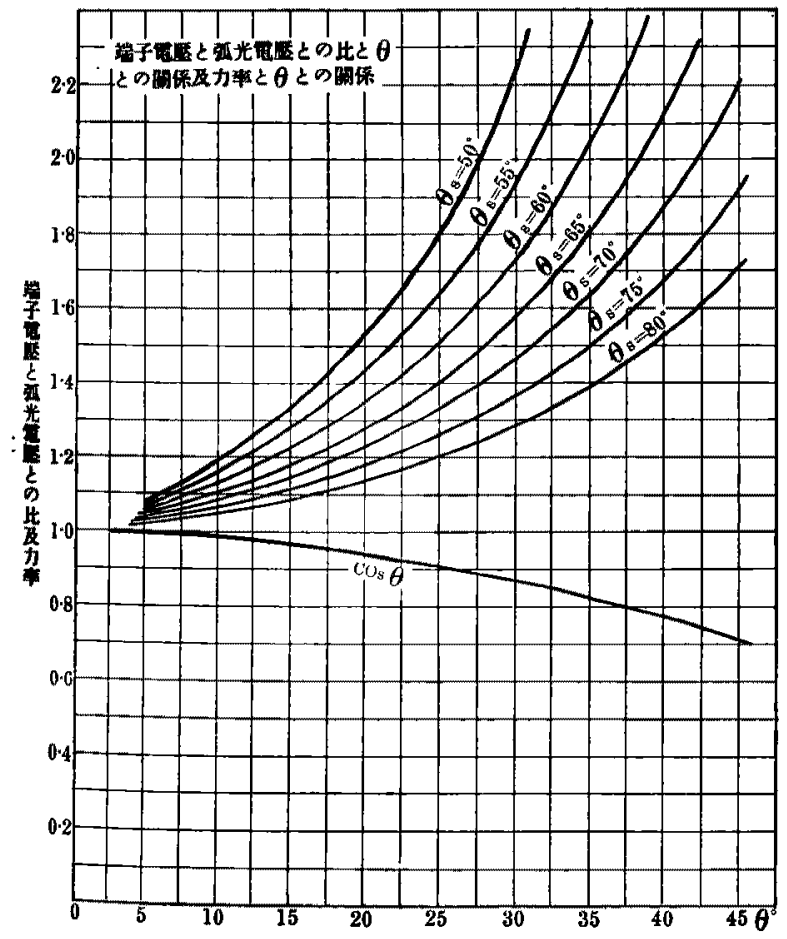

或了短絡位相觕に付て帣人ますと、例一ば $\theta \mathrm{s}=80$ の谒合であり

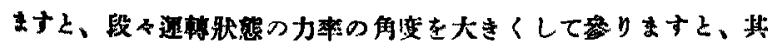
臬恃之一向つて來ますからしてノーロードの管堐との此とは段な

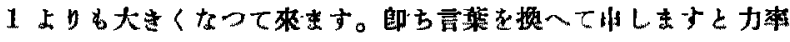

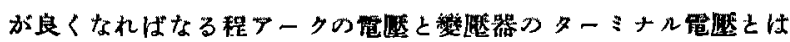

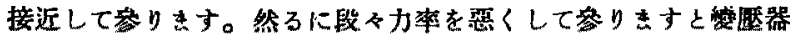

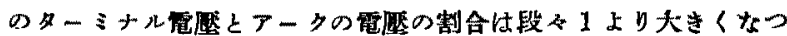

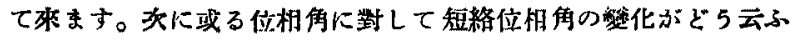
影繁があるかと申しま士、短絡位相伤 $\theta \mathrm{s}$ が大きい場合の方が

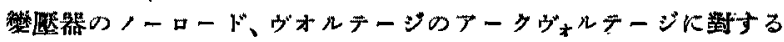
倍率が小さくなる、段此角度 时が小さくなるに從つて、ターミ

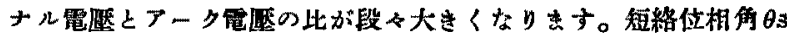

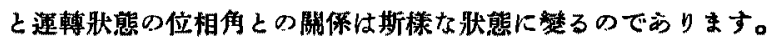

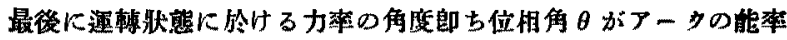

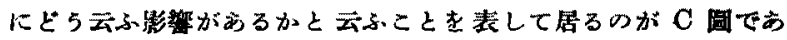

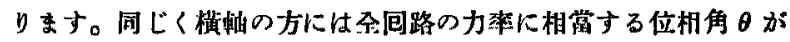
出て居ります。之れから縱軸の方にはマークェフイシェンシー即

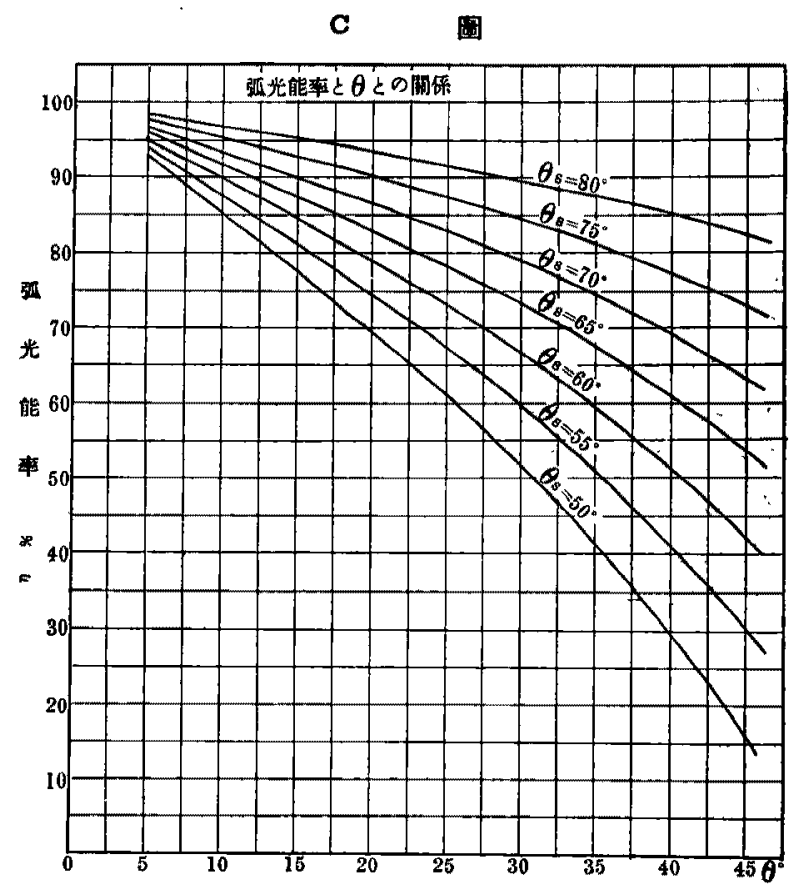

らアータに依つてヒートエナージにコンバートした霄力の供給、

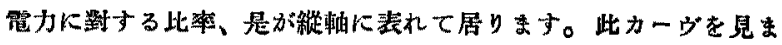
すを、短絡位相解 $\theta \mathrm{s}$ が同じでらる場合、例一ば $\theta \mathrm{s}=80$ の場合 に就て見すすと位相觕 $\theta$ が小さい埸合には $100 \%$ К近いのであ

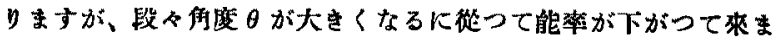
す。言换人れば力率が良い時には能率が良いが、力來が留くなれ 壮能率は段や下がつて本ると云ふことが一般の傾间で方ります。

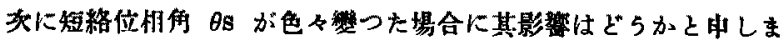

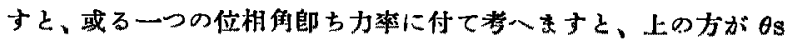
が大きいのでありりして、下の方が小さいと云ふととになってる

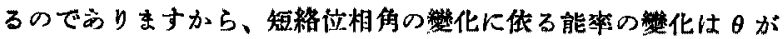
大きければ火きい程大きくなつて來ると云ふことを示して居りま す。此三つの圆表に現けれて居ります關保を概括して申しますと

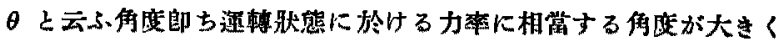
なれば、其結果として短絡電流の比率は小さくなる。それから程

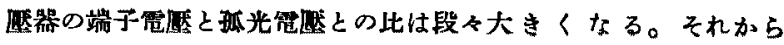
坬光能來は $\theta$ が大きくなる程段々下がつて來るのであります。そ

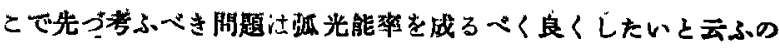


が完氮煴に於ては大事な開題であります。でありますから出来る

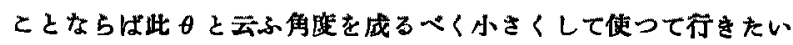
と云ふととを先ず考ふできでありませ5。官換人れば力率性る くく良く伴つて行くと云ふ事が最も大事な問題であると思ひま す。幸なる哉成るこく㑊小さくして力率を良く使つて行くと云ふ

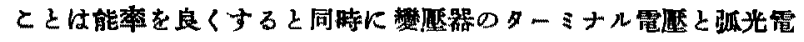

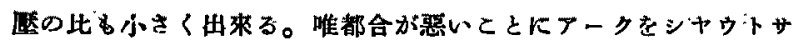
一キットした場合に通る電流が規定電流に對する倍率が非常に大

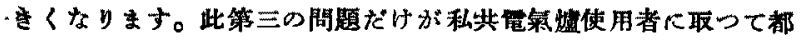
合の㦞い條件であります。短絡電流の大きいと云ふととは御承知

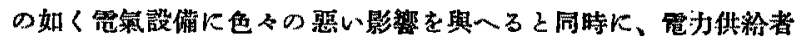

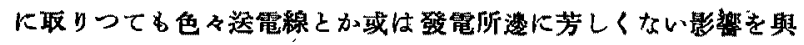
八未すからして最も缄をつけなければなら好と思ひます。併しな

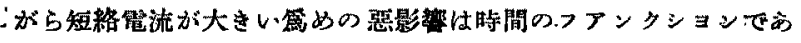

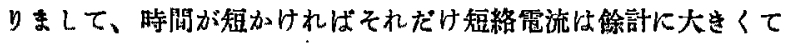

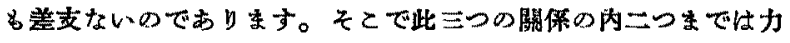
帮を良くすれば良くする程宜いのでらりますから、此第三の開題 を何とかして橡防が出來れば宜いのですります。幸ひに短絡電流

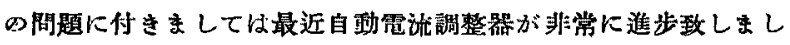
たので、之に依つて短絡電流の時閒が可成り短くなつて居ります

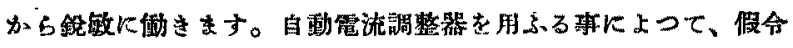
短絡電流ら值俚大きくなりましてる其時間と云ふるのを極度に短

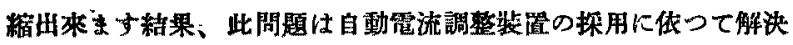

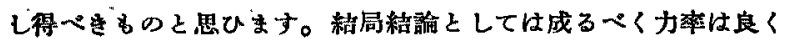
使つて行くを云ふ来になつて東るのであります。然らば力率を良 くすると云ふ事はどら云ふととかと申しますと、声りアークの举

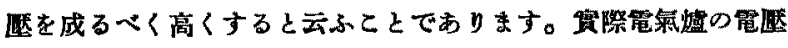

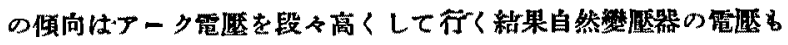
高くなる傾向が影者であります。私の申しましたてと〉赛際最近 に於ける一般の䝨向とは一敘してて居るのであります。そこでアー

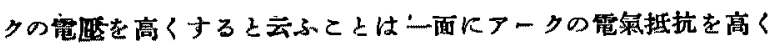
すると同じとてであります。それに付きしては今日午前中の敋 铞の場合に一寸中上げましたが、是には或る一定の限度があるの でありまして、之に付ては今後治金の方面に於て大いK研觉すべ

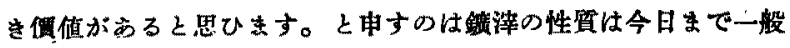
治金學者に俄つて将一られて居るこ上は銅の精鍊を主眼々して居

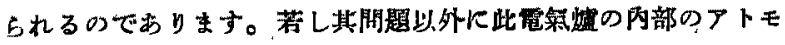

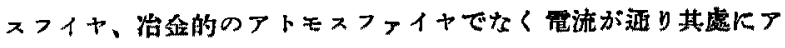
ークが通ずる、其アークの通るぐ道路にあるアトモスファイヤが アークの電策抵抗を成るへく高くする中らなアトモスファイヤを

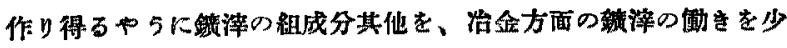

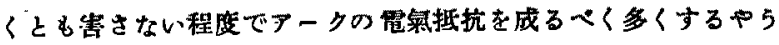

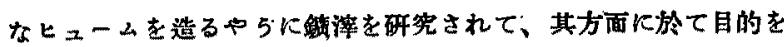

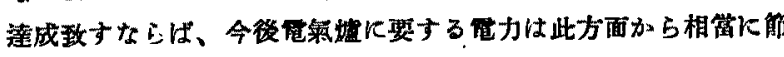

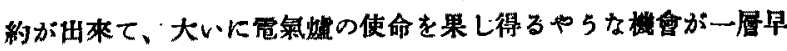

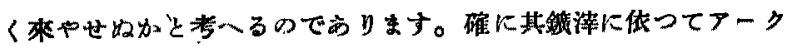

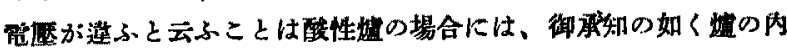

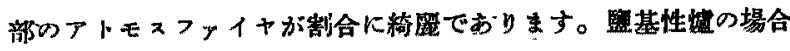
には色アのヒニームがありまして、アークの抵抗が少いやらに常

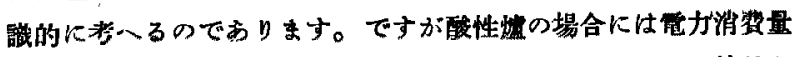
が少いと云ふことは無諭他にも原因があるのですります。特斜を しないと云ふことに伐つて䉓力消䩀量が少いのですりますが・れ

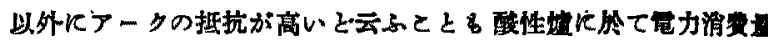

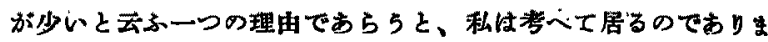

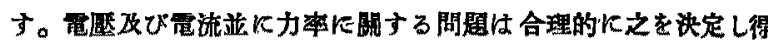

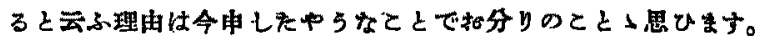

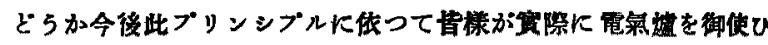

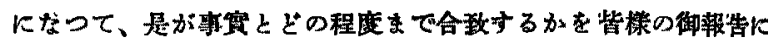

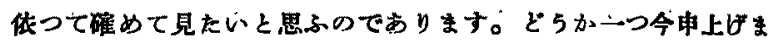

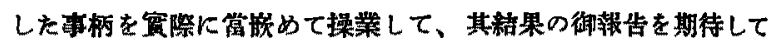
止まない第でありりす。(拍手)

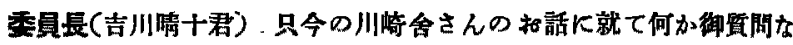
り御意見なりがどざいましたならばどらか御进を碩いすす。

47 番(港田長策君) 川崎舍さんから只今色く御話を何ひましたが、

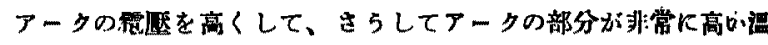

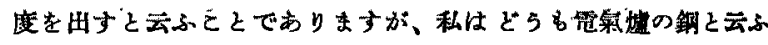
ものK維しては非常と大きな疑問を持って居るので的りす。是

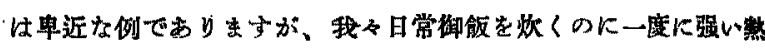

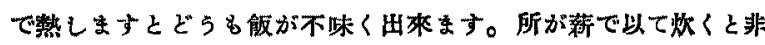

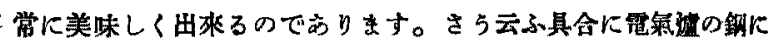

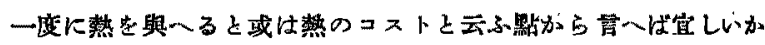

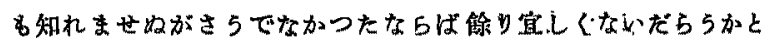

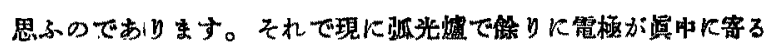

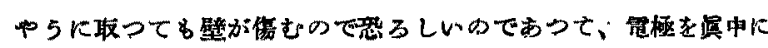

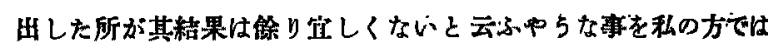

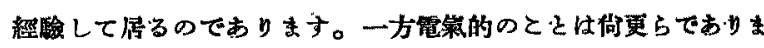

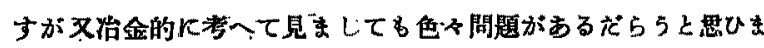

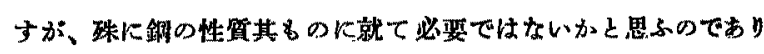
ま。

員長(吉川晴十䏒) 外に御意見はありませ字か。

49 番(向山幹失居) 今の淺田さんの和話は諴御尤であります、先

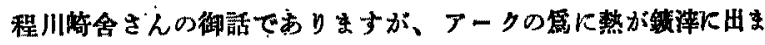

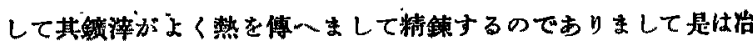

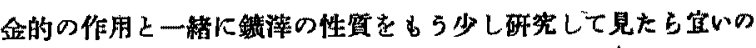

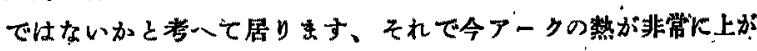
ると云ふことを电されましたけれどい、私僅加の葢驗であります が、其察政の結果に依りますと、そんなにアークの温度はどんど

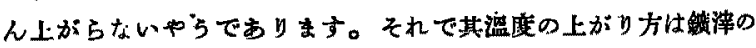

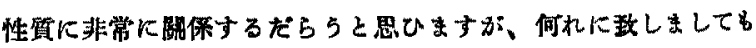

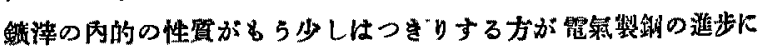
貣献するだららと思って居ります。

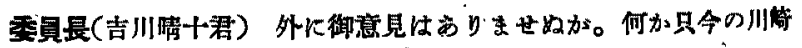
舍さんの机話以外でる、此三うの項目につきまして、郎ち 133 、

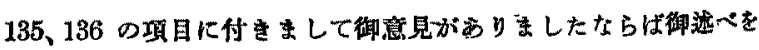

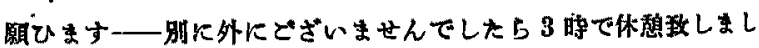
て、後の140、152、153、154、156 と是だけを像定して居ります

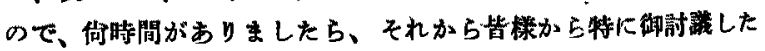
いこと、仰言るやらなととがありましたならば御討哜を願ふとと に致しますそれでは 3 時まで休㮩政します。

\section{一休 巍一 \\ 4午视 3 時“開會}

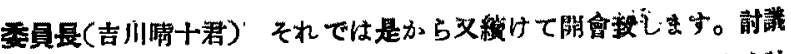

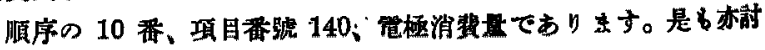

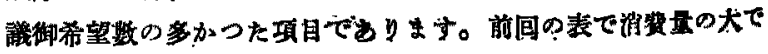




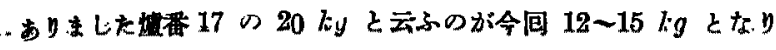

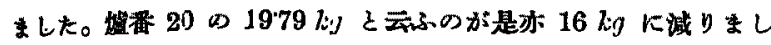

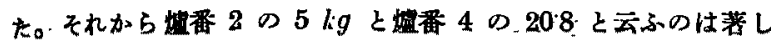

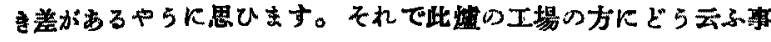

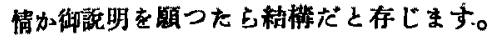

19 番(菊田多利男君) 安來の方は急に用がありをして昨晚歸りま

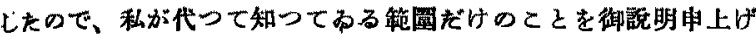
ます。此 $5 \mathrm{~kg}$ 亡するのは間蓳ひだららと思ひます。很處は特殊 特が主ですから、西力の消费最も非常に多いのですから、從つて

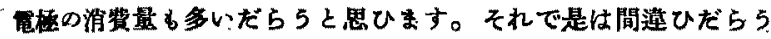

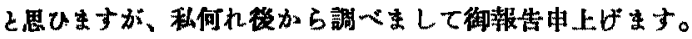

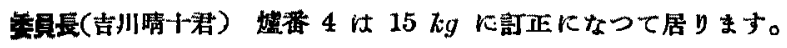

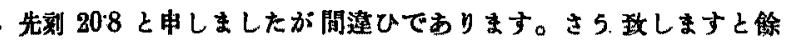
ク外と䢙はないととになるのであります。只今の安來裂銅所のが 是より多くなると云秃ととになりますれば、稌り著しい邀ひはな いや5K思ひますが、此项目に於て份御意見がありましたら御退 でを碽ひます。

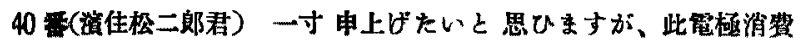

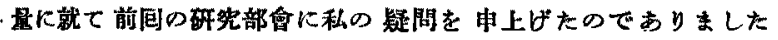

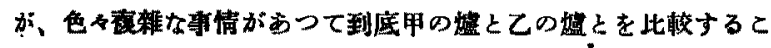
とが出來ないと云ふ回答に到澾したと思ひました。然るにる拘は

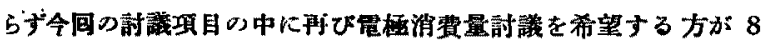

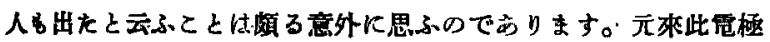

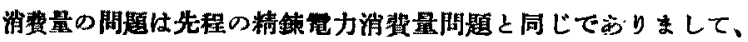

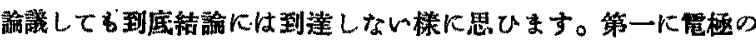

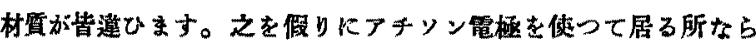
ば夫丈けで此较するとか、或は日本かーポンなら日本カーポンの 些極を使つて房る所同士で比較すれば宜いのでありますが夫が皆 湿合して論じられてわるのでありますから無理だと思ひます。第

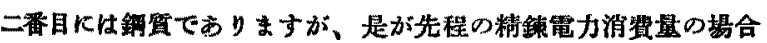
と矢張り同じ路保でらると思ひます。特殊銅の非常に高いるのを

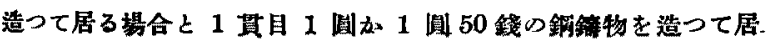
る坦合をで全然時消が荤ひますから之を較べることは無諭出來ま せ如、それで先程值段に恢つて輘べたらどらかと言ふ畨なとしを 申上げて見をのですります、無諭差物を找いた湯の值段を申した

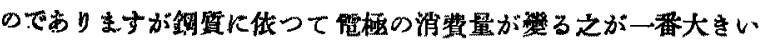

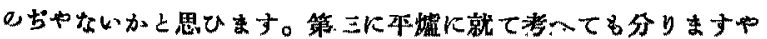

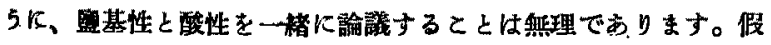

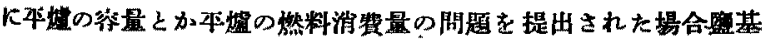

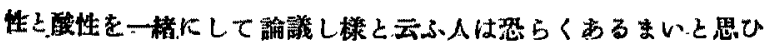
ます。であります加ら之等の點を完全に區別した上に、初めて䗈

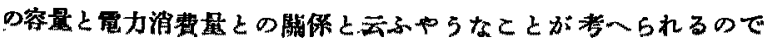

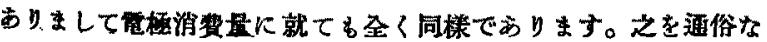

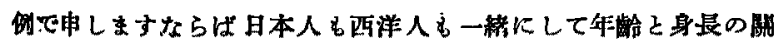

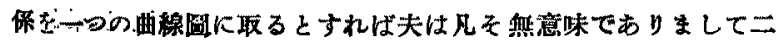
つの曲楾略に别けて始めて有意莪となり变せ5。私が進行保を跑 めるやらなととになりますか、是開題は早ふにして片付けた方が 息いのではないかと思つて届るのでありりす。

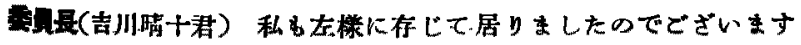

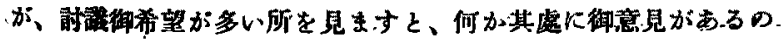

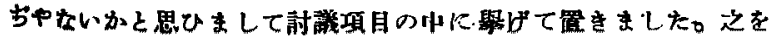

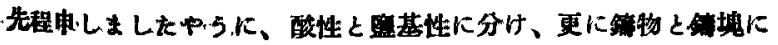

分け、及些通銅之特殊制に分けますると、是住大抵一つか二つに

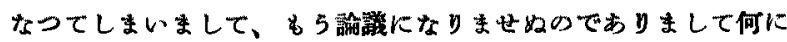
、表出出來ないと云ふととになります。るれで討議御希望を申出

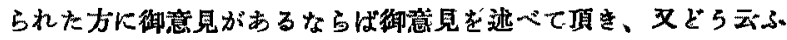

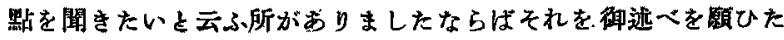

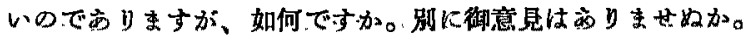

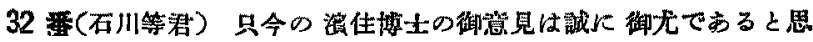
ひますが、併し委員長の御話のや5K、電極は䉓力と同様に此仕

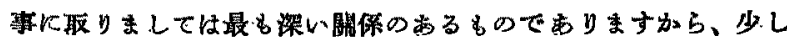
ばかり御參考に息見を述へてて見たいと存じますから 2 3 分時間 を頁戴政したいと思ひます。

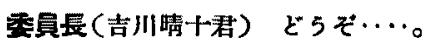

32 番(石川等君) 前间の研究部會加問題になつて居りました管

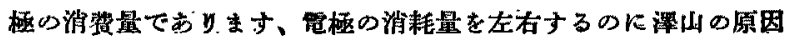

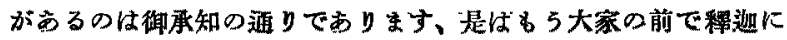

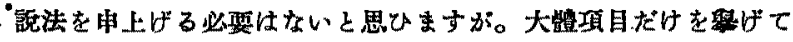

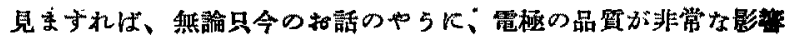
があると云ふととは、党然であります。人造黑鉛であるとか天然 墨鉛であるとかに依つて非常に違があります。炎には製植的使用

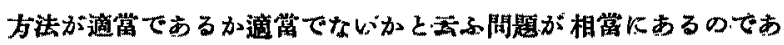

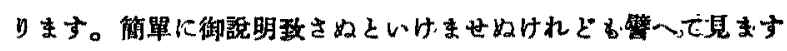

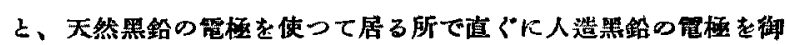
使ひКなつてしま5のであります。ホルダー其他の關保で径來 8 吋の天然黑铅の電極を御使ひになつて居る。其虚一持つて來主し

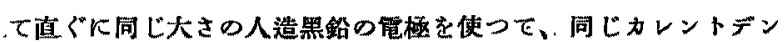
、シティを探用する場合を考入て見ますと、人造黑颌の霞極の埧の

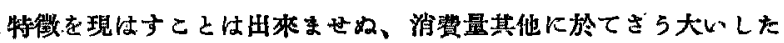

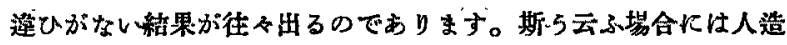

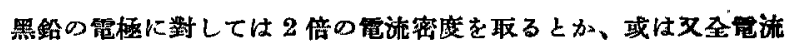
に對してェレクトロードのサイズを5んを細々して使ぶ必要があ

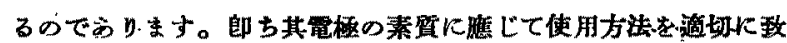
さないと良好の䋹果が出て來ないのであります。丁度人間む使ひ 途が適常で方れば非常に役立つのでありますけれども、之起讙れ

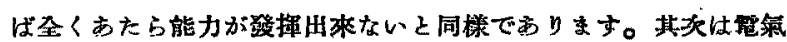
㠊の形式の閶保であります。例一ばメルーであるるが゙ローであ るとかレンナーフェルドであるとかと各種の型式があるのであり

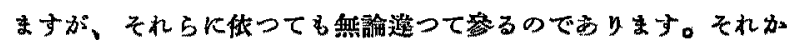

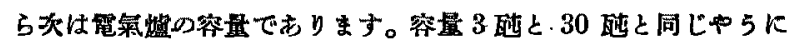

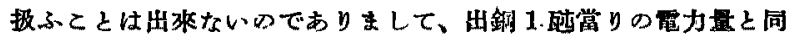

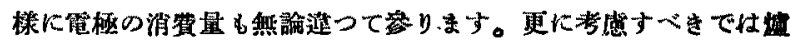

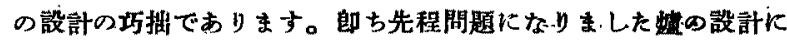

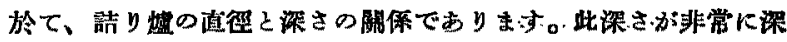
いのは他は同一條件の䐈に此でて䄪 2 倍以上の電極を消留した宁 例があるのでありますから、一考の価値ある次第と思ふのであり

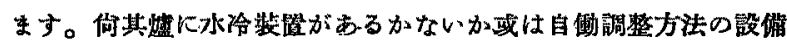
があるかむいかと云ふとと、是等に依つても勿論逢つて望るので

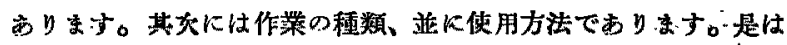

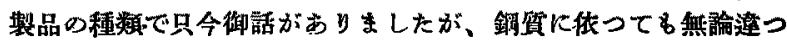

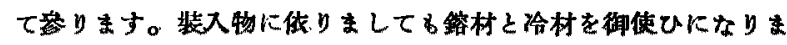

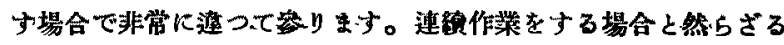

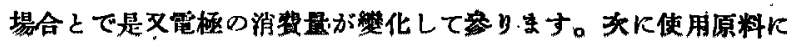

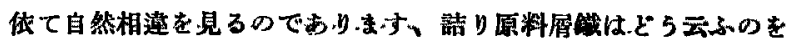


使ふか、或は大きいとか、小さいとか、或は非常に醊化して居る

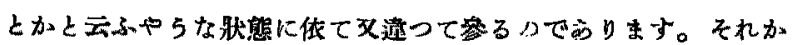

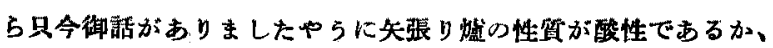

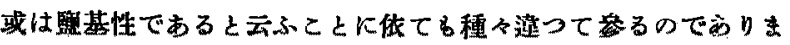
す。斯の如く何他にも種な條件がありますけれどる、斯5云ふ風 な湿山のフォクターに依て、電極つ消耗量が左右されて來るので

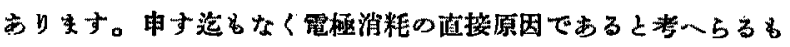

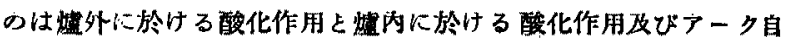
身に依る洞粔ですります。而して大體只今日本で䉓氣整銅に御使 ひとなつて居ります管極の種類は、之を大別すれば、先程御話の

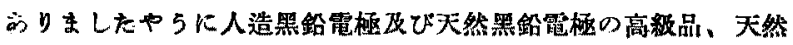

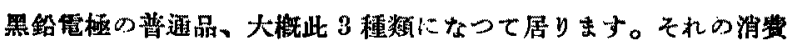
量の大能の数字を申上げて見たいと思ひます。是る先程申上げま したやらに、非常に少いのと然らざるしの上があるのであります。

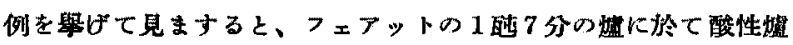

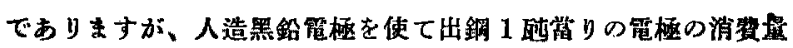
が $28 \mathrm{~kg}$ と云ふのがあります。是等は制合に少い方で、此表の中

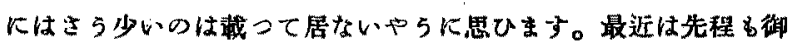

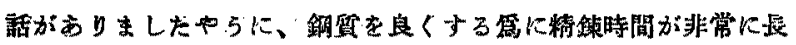

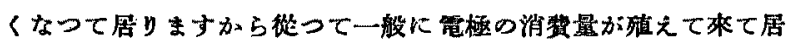

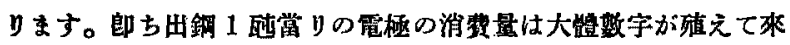
て居ります。只今中上げました备種のファタターに依りまして可 成り遠ふのでありまして、其閏きが割合大きいのでまりますが、

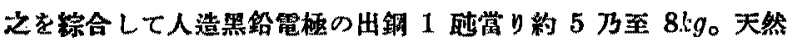
黑鉛植極の高乘品か5 55 乃至 $12 \mathrm{~kg}$ 。それから天然黑鉛管極の普 通品が 8 乃王 $15 \mathrm{~kg}$ 。扈が令まで各方面で柜使ひになつた實際の

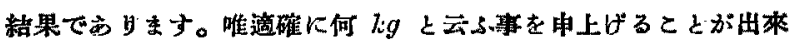
ないのは䌅々申し上げました種ななるファタターに左右される第 である事を御袮察願ひたいと思ひます。

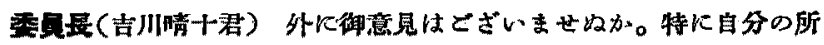
は少いが他所は多いとか、斯ら云ふ風にやったら宜からうを云ふ。 ○らな御意見でる何ふととが出來ましたならば幸ひですると存じ 250

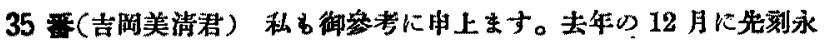
井さんが据話になりましたナショナルカーポンのポスボー氏

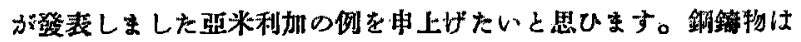

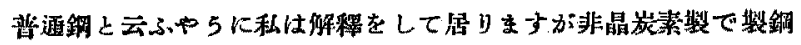
米噸 $(2,000 \mathrm{lbs})$ 賞 り $9 . \mathrm{lbs}$ 乃至 $20 \mathrm{lbs}$ 。人造黑鉛で $5 \mathrm{lbs}$ 乃至 $12 l b s$ 。それから銅塊と書いてかりますが、是は高炭素鋼、合金

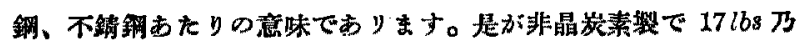
至 $30 \mathrm{lbs}$ 。人造黑鉛で $10 \mathrm{lbs}$ 73至 $20 \mathrm{lbs}$ と云ふことを發表して 居ります。是は今石川博士の仰言つた教字と上く似て居りますか

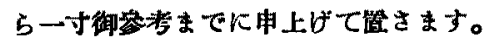

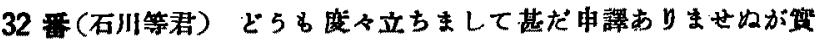
は积共の發零し得る機會は電極問題より以外には硝んどないので ありますから执許しを碩ひ主す、製銅には全くの素人ででざいま

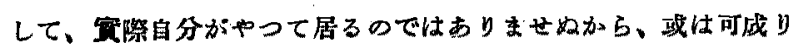

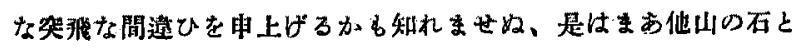
敉しまして、只合の委員䱋の御意見に俵りまして斯らしたら宜く はないかと云ふゆらな素人の思ひつきを御考要でに电上げて見

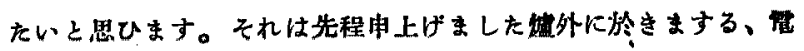

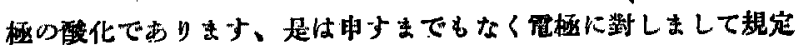

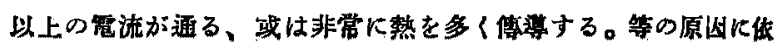

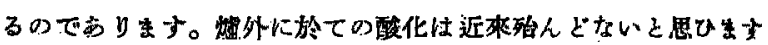
けれどす起り得る場合を稳想して专八て見末すると、先づ第一に

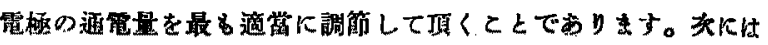

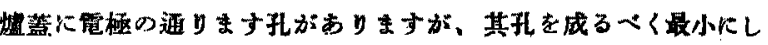

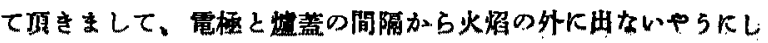

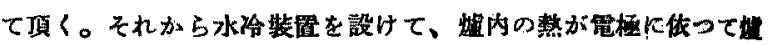

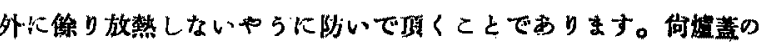

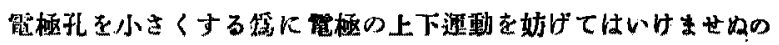

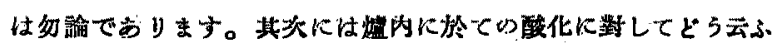
や5に考一たら宜いか。是は先程申上げました管氣晴の㨁得之梁

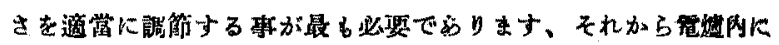

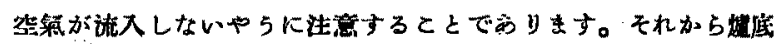

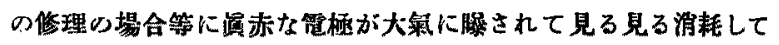

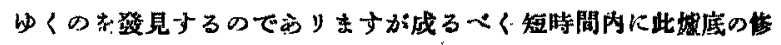

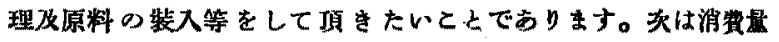

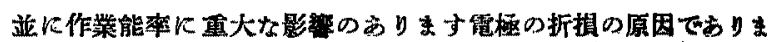

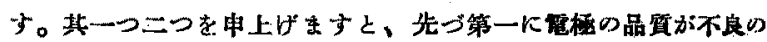
場合によく折損を起すのであります。其灾に管極のホルがーの中

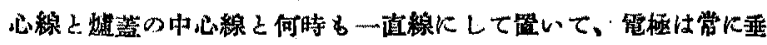

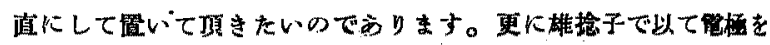

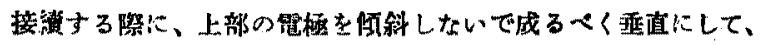

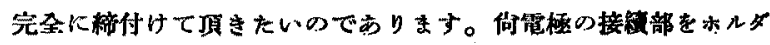

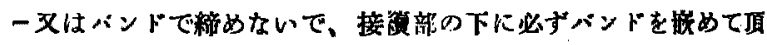
き其接縜部は成るん!ターミナルの上に行くやらにして而きたい

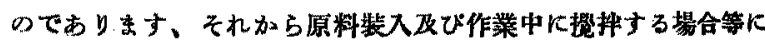

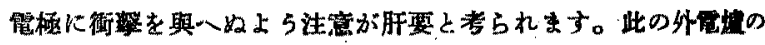

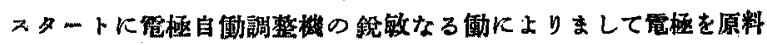
塊に激突せしめ之を析瑁する場合が往ふするのですります。止上

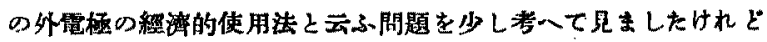
す、䚙り長くなりますから、此位で止かて镇きます。

委員艮（䓃川晴十君）其外に御意見はでざいませぬか。

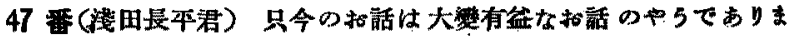
すが、時間がないと云ふので速く申されましたので私は允分によ く疆取れなかつたのでありますからして、どらか詳しい御紫告を

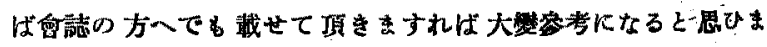

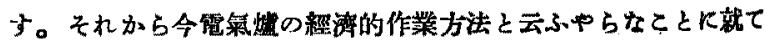

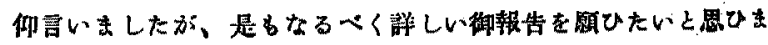
与。

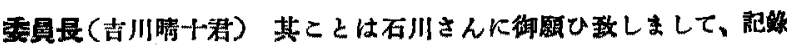
のみへです迫つて載せて顶くことが出來れば大警宜しかららと思 ひます。外に何か御意見はございませ始か一それでは色な有盆

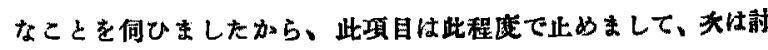

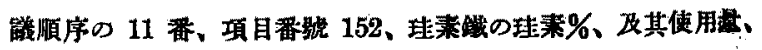

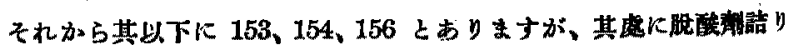
品留に開する問題がありますが、是は知张り重要のととな存じ す。此虎で此表の中で一寸氣のつきますととは燔 16 で $75 \%$

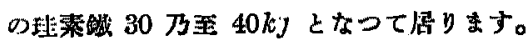

25 番(堸切政康君)それは 3 乃至 4 の間量ひであります。

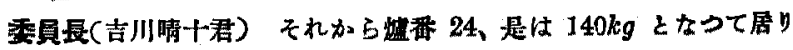
ますが....

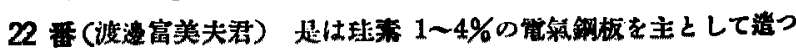


てるるからでらります。

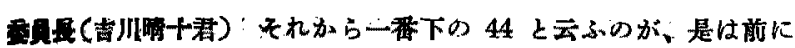
$40 \mathrm{~kg}$ とありましたのが $13 \mathrm{~kg}$ に直つでります。さら站します

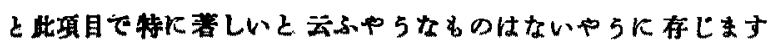

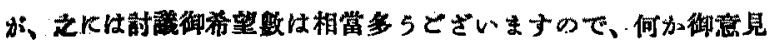
がありましたら御遮でを愿ひます。

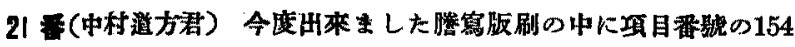

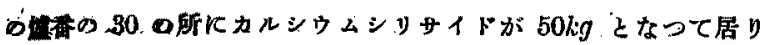

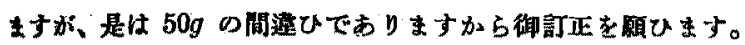

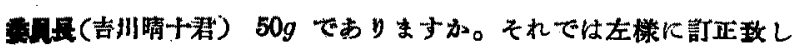
ます。きれでは此项目の所では何か御意見はどざいませぬでせ5

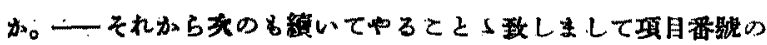

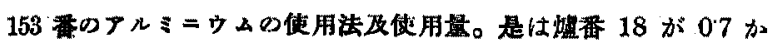
ら 12 とかって居り主が、是は一寸多いやらに思ひます。それ から惟 29 が 2 3 Kなつて居ります。そからいつと多い所

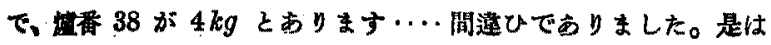
04 K值つてあります。ボイットの间違ひですりましたから此分 U虫消します。前に申上げました燔番 18 は何か特别な理由があ るのでありますか。

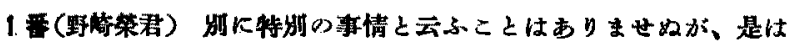

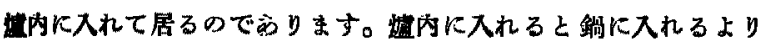
る時間汃大分前になりますから、少し俆計入れた方が宜いだら5 そ恩つてきれで餘部入れて居るのであります。

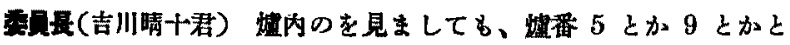

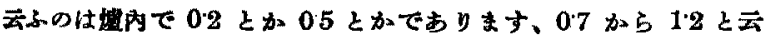

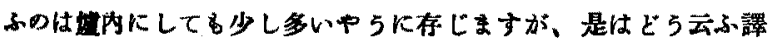

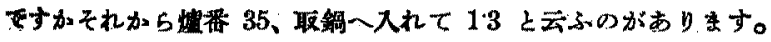

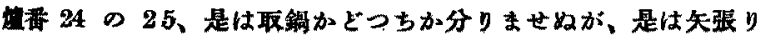

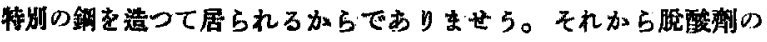
多い少いと云ふととは、品蛩に俆程影整があること〉思ひます

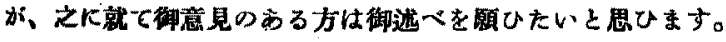

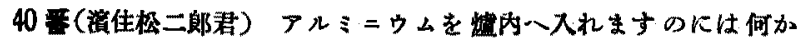
良いか法がありますか。

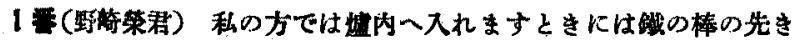

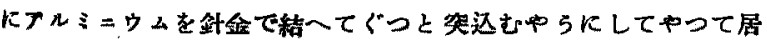
ります。さらするとよく蛒解するゃらですりりす。大抵 30 秒閌 位で鉻けてしまいます。

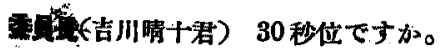

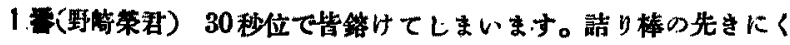
つ付けて㬅中に突込むのです。

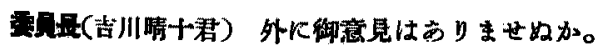

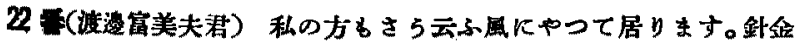

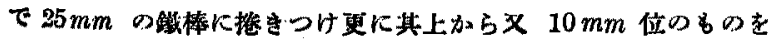
港き付けまして笑込んで居ります。知張り 30 秒乃至 1 分位で路

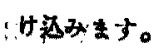

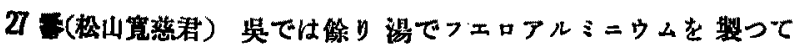

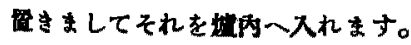

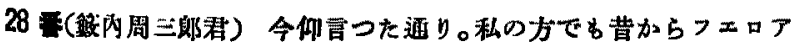
ルミニウムを蛊內一入れるやらにして居ります。一度アルミ゙ウ 山を其睢投入した所が非常に失收したことがすりりす。それはア

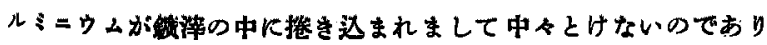

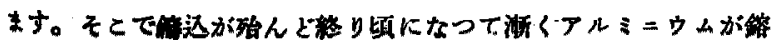

けて來た篬に最後の晹になつて非常にアルミニウムが多くなり湯 の流れが惡くなりストッパーが塞つた事がかります。

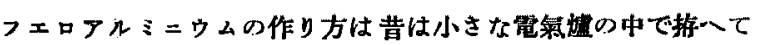
居つたのでありますが5〜6 年以來は今仰言つた通り小さな取銷

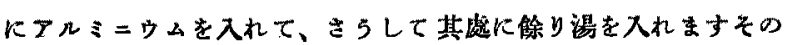
易は約 2 揢位のアルミニウムК相常します、さらして出來たるの

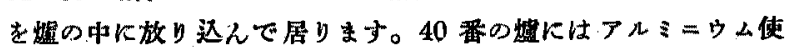
用量が出て居りますが、是は制物だけに使つてみるのでどざいま

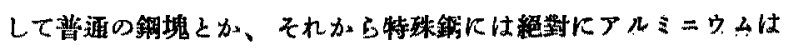

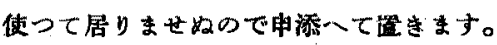

21 告(中村道方君) ビ5む此アルミ゙ムを使ふと云小のは情性

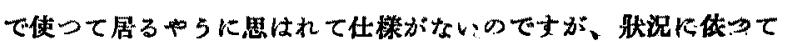
も罢りますが大體どれ位使つたら宜いのか、或は使つた場合と使 はない場合にでどれだけ違ふかと云ふやらな御經騟がありました ならば侗しをしたいのであります。

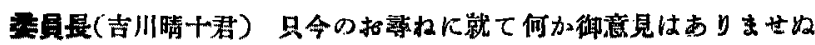
$\$ \times 0$

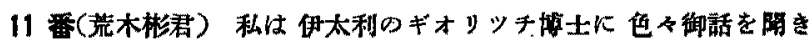

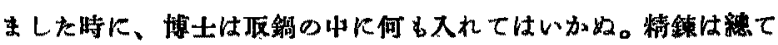

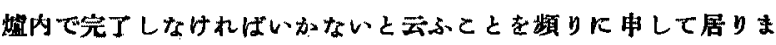
した。むる㾏ど本常の良い銅を造るのには取鍋いアルミニウムを 入れると云ふととは確に良くないととだと思ひす。其啙は只今

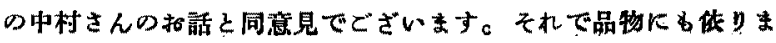

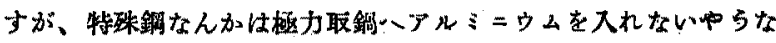
方法を研究して頂いたら銅留がもつと良くなりはしないがと思ひ

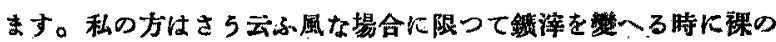
晹の中一アルミニウムを放り込む事がありりす。それで大抵聉常 $1 \mathrm{~kg}$ 位使ひ寺すと湯が非常に静かな晹になりまして、それからず つと 2 時間位精鋝して出銅しますから、さ5するとフルミ゙ウ

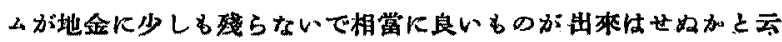
ふ風な考で時々やって居ります。但し之れは果してよい方法で古

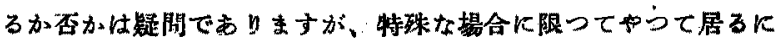
過气゙まん。

委貝長(吉川晴十君）只今のは何時アルミニウムを入れるのだす s.

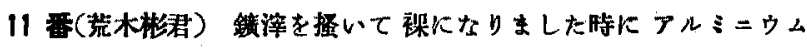
を入れまして、其上一概硫鑑涬の配合したむのを投入します。さ らすると初めか巨非常に埆かなよい湯が出來ます。

忝是長(吉川啨十君) アルミニウムで還元してやるのですか。

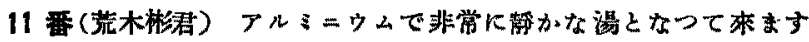

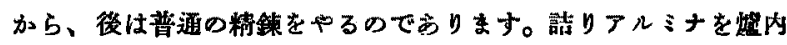

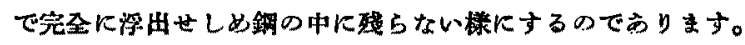

至買唇(吉川晴十君) 撮後に使はないのですか。

11 番(荒木涁君) 最後に使ひたくない場合にはさら云ふやらな方 法を時ふやつて居ります。

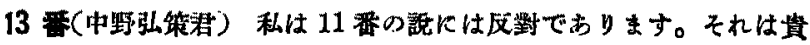
更なアルミニウムを初め晹の荒い時に脽酸に使ふと云ふことはど

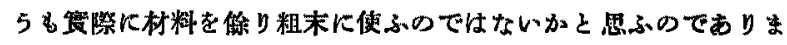
して、是は如何なものでありませ5か。最初はマンガンとか、シ リコンとかを使ひまして最徐に一番值の高い贵重な而も分基の制 合少いやらなるのを使つた方が有效ではなかららかと思ひます。

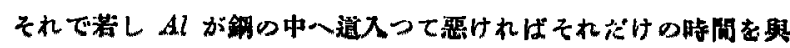


八でやると云ふ風にした方がよくはないかと思はれるのでありま す。

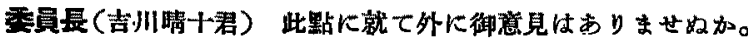
21 蟠(村道方君) それではす5一步進んで全然使はなくつて恙

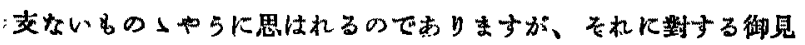
解を何ひたいと思ひます。どらす形式的に流れる氣味がありまし て、之孛る5一齿淮んで行けば何にるアルミニウムを使はなくて

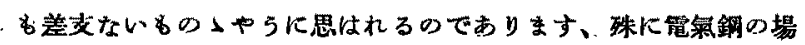
合に於て左粎に考一られるのであります。

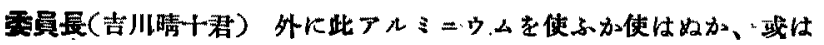
、使ふとしたら何時使ふと云ふやらなととに就て御意見がありまし たら御述しを願ひます。

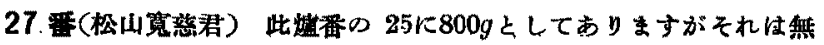
諭鐿物用であります、他の鋼塊類は現在約 $100 g \sim 500 g$ を用

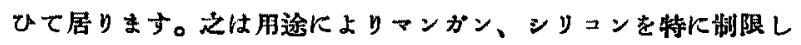

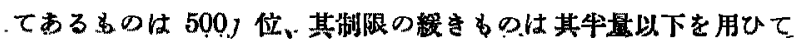
居り孪す。

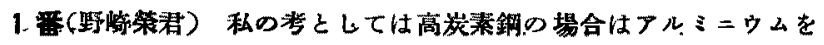
使はぬでる少しる棰は好と思ひますが、低炭来鎆の場合はアルミ ・シウムを使はないと氣孔が出來ますから其の場合にはアルミニウ ムを成るてく使つた方が宜いと思ひすす。是は寅際の絬果は可な

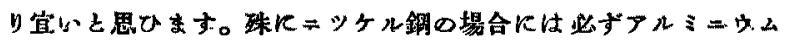

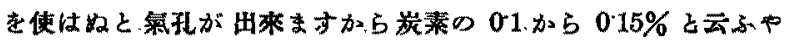
らなあのにはアルミ゙ゥムを使ひます之氧孔は全然出ませ如。そ

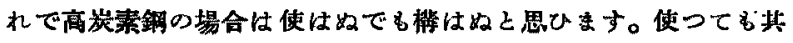

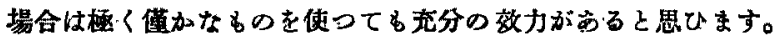
それで主なる歹目的は此氮孔を防ぐと云ふ所にあるのではないかと 思ひす。

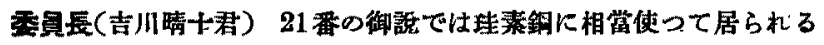

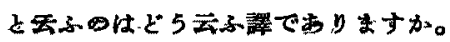

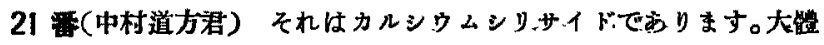
アルミ三ゥム性かしか使はないでカルシウムシリサドイを主に 使つて居ります。

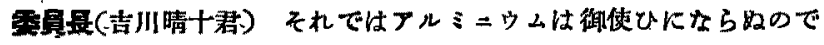
J加。

21 番(中村道方确) 主としてカルシウムシリサイドを使ひます。さ 5すると眼酸生成物が流れる良く浮をる良くなると思ふのであり ま。

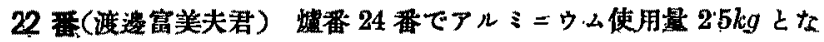
つて居りますが、是は麗氮銅鈑を主として制造して居ます開保上

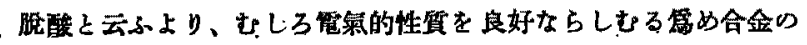
目的に体り使用して居るからで卸座います。

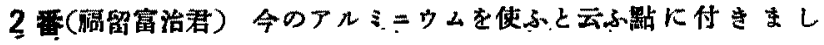
て、私は只今の野愉さんの御顶に同意するものであります。炭素 が高くて、炭化石灰鐵涬を以て完全に脫酸し得るものでありまし たならばアルミニシムはさ5多量を必裂としませ妨が、炭素が低

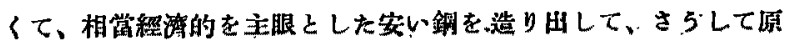

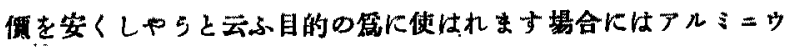

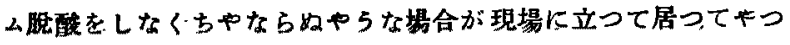
て居る時には、時たまするやらであり去す。それで只アルミ゙

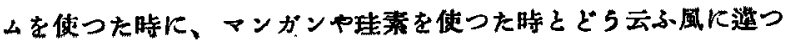

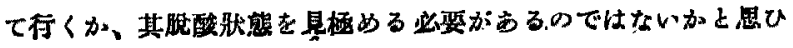

ます。それを墥際に於て見ますと粗裸湯なんかに於てはさらでる

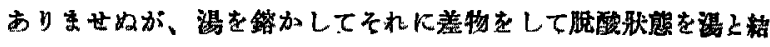

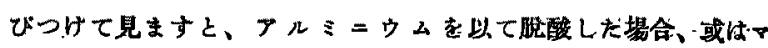
ンガンで胎酸した埸合、或は恄素丈けで脱酸した場合、或はシり

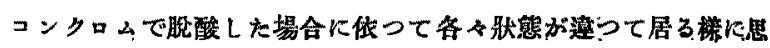

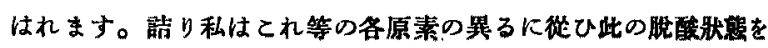

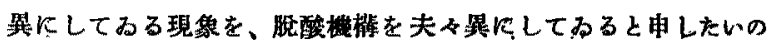

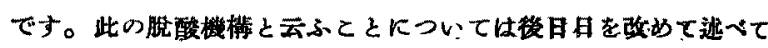
見たいと思つてあるのでありますが單に概を完了した为ら良銅

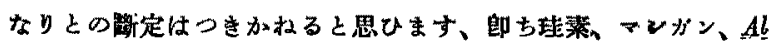

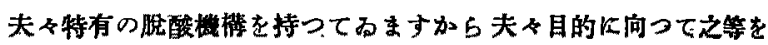

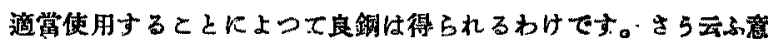
味に於きまして、それではアルミ゙ッム使つた場合に其絬果が

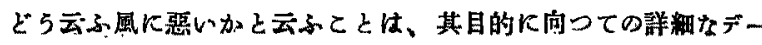
タがありま世好から分りませ好が、單に庭延をした場合にはすら 繁害があるとは思はれないいらででざいすす。併し乍ら=ッゲル

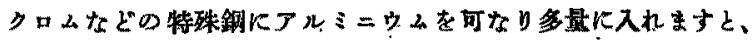

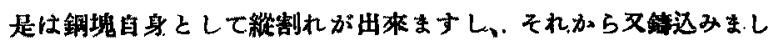
ても、其鎆込の形爿の被雜した部分の所には制目がよく現はれる 上云ふ中らな事は上く踪際に於て度な出會ふ何ですります。一寸

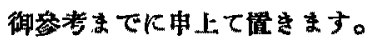

8 番 (艋內周三郎君) 只今色々何ひましたのですが、先程加ら使 つた方が宜いとか、使はないが宜いと云ふ御意見に分れて居るの を伺ひます、是仙要するに各々造つて居られる種類に關保して 居るのでないが思ふのであり寺す。私共の方で造つてるるのは 兵器などに使ひます特殊な鎆でありますから、非常に材留の良い 物を要求されます、斯ら云ふるのを造ります場合には、精鍊上ア ルミニウムを使はなく、てるよいといふ自信のする注意深い作業か 必要と思ひます。即ちアルミ゙ンムを使はない方針でなりればな らんと思ひます。

一面に於でッタルの通入つた銅にアルミ゙ウムを使つて失收

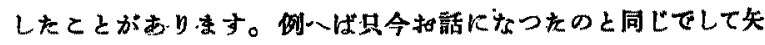

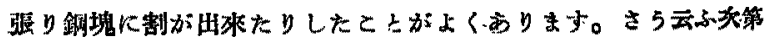
で、令まで私共の方の工場などの例を見ましても最业前加らつ て居る者はアルミニウムを使ひたがるのであります。是は先程括 話がありましたやらにどらる惰性ではないかと思ふのでありま

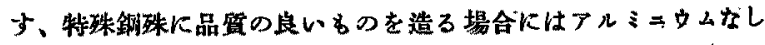

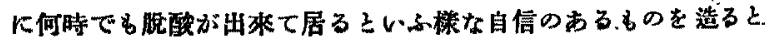
云ふことが一番大事古とをでないかと思つて居ります。私性す ルミニウムを使ふと云ふてとは非常に哮ひでありますが、先年佛

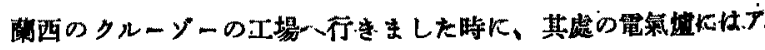

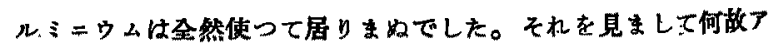

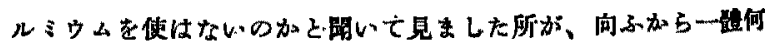

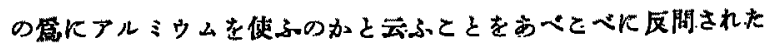
のであります。其答一は私が言ひたいを思つて属つたてとで、自 分むさ5宩八て居たのでありまして、自分の言ひたい.を思つて居 つた言葉を開き非常に我が意を得たと思つたのであります。それ

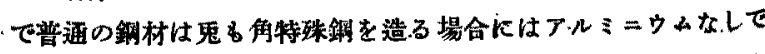
立派なるのが造れるや5とするのが宜いだららと思ひます。ど5

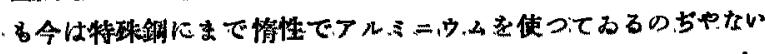

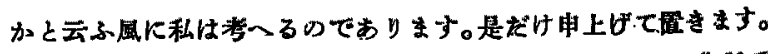

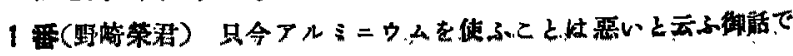




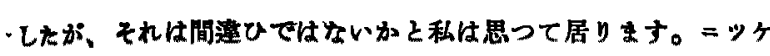

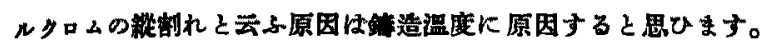
それが高いと必す割れが来ます。それはアルミニウムを入れた第

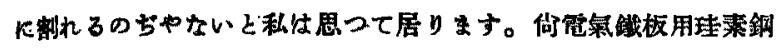

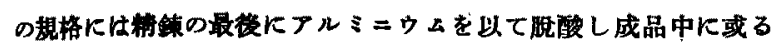

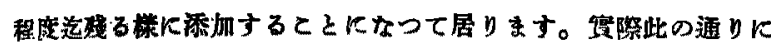
莫行して居りますが粠果は非常に宜しいのであります。献するに 使用量を除票にようて加隇するのがよいと思もます。

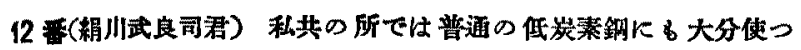
て居るのでありますがてれ等にはアルミナが入つてわて割れて管

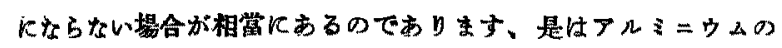
使ひ方によるので上手に使一代害はないかる知九ませんが浸然上 使へば却って害の多い場合を䋎驗して居ります。 フルミンウムを使ぶ場合には其使ひ方を研究する必裂がある上考 レます。

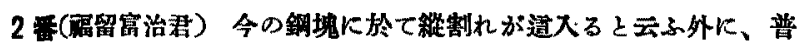

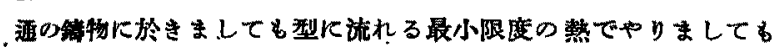
フルミ゙ムが多い場合には割れるてとは確かに嘪驗に依つてる 明かでありまして、そにもアルミニウムを你小限界があると云ふ てとを明加家騟に於て示して居るのではないかと思ひます。

委負長(吉川啨十君) 其割れのととに就ては何か 理風がつけられま 广加。

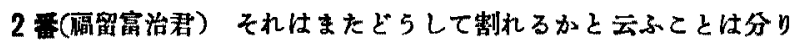
ませ好です。 アルミニッムが多ければさら云ふ可能性が非常に多 くなつて来ると云ふととは事察に於て明らかに分っただけであり ましてどら云ふ理由で制れるかと云ふことに付きましては、まだ 俆程研究して見なければ分ないことだららと思ひます。

15 番(涌田十头君) 其アルミニウム使用限界之云ふのは大體どの 位と御考一になつて居りますか。其點をむ5一胙何ひたいと思ひ 小。

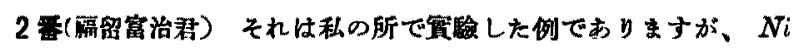
$375 \% 、 C r 1 \%$ 内外、C 03 加 $504 \%$ 位の鋼於きまして、出銅

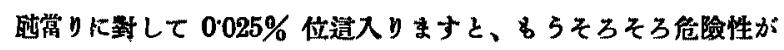
增して柬るやらに思はれます。必しるそれで全部制れると云ふ摆

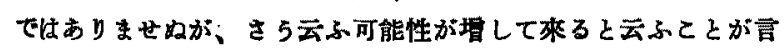
一るだららを思ひます。

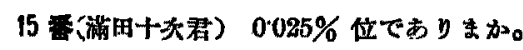

2 爵(麗留富治君) さ5です。

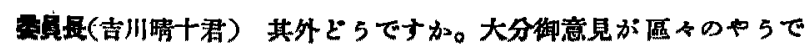
カりますが。

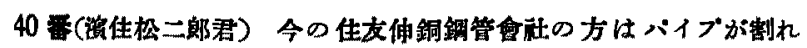

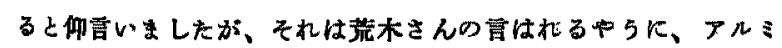
シウムを入れた場合でもさ5云ふ渞向が条いのでありますか。

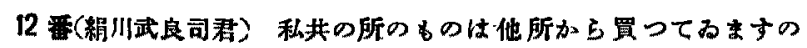

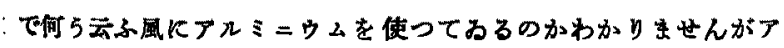
ルミナの入つてるる點から見てアルミニウムを使つたてと丈は磪 加と存じます、そ机等のメーカーは一ト申し上げ策极ますが。

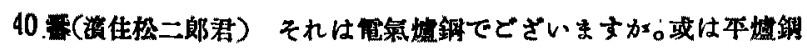

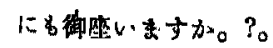

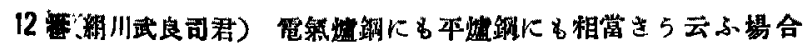
があり舀す。

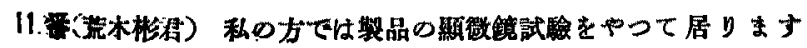

のですが倍率を一寸多くしてゃりますを、アルミニウムを使つた

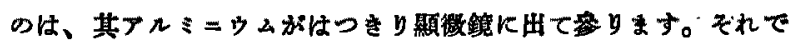

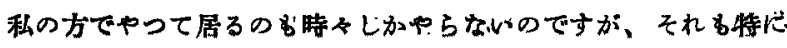

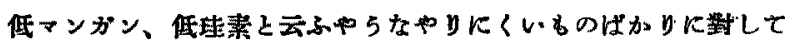
やって居るのでありますが、初めに入れたアルミニウム山砦徽鏡 で見てる少しる出ませ好ですが、取銅に入れた場合には必ず其の

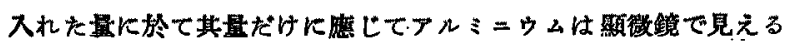

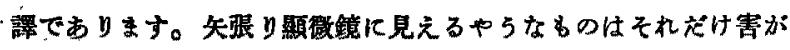
あるのぢやない、斯5考人て居ります。

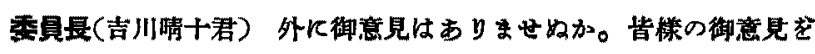
何ひますと云ふと、アルミニウムは瑟い之云子御意見の方方、“多

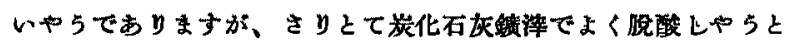

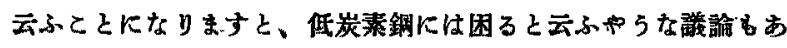

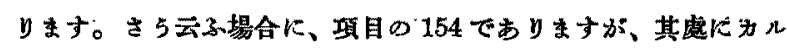
シシムシリサイドのてとがあります。先到 21 番は之を使つたら 宜いと云ふ御意見が出て居りますが、併し低炭素銅の埧合、或は シッタルのスつを場合あたりにカルシウムシリサイドを御使ひに なるととは如何でありませらか。文に就ては前司の研究部會の時

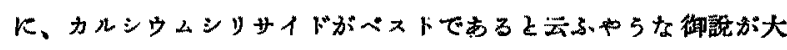
同䉓氮製銅の方からどざいましたのですが、是は如何ででざいま す为。御意見を御述へを原ひます。

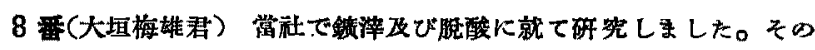

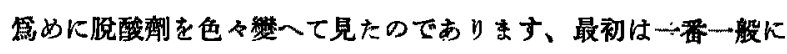
使はれて居るシリコン、シリコンマンガンを使つて見たのであり ますが、その後カルシウムシリサイド、ーラルヂット、フルミン

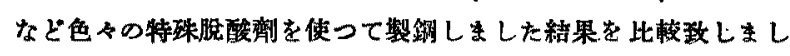
た䊀果、カルシゥムシリサイドでやつた銅塊が一番在びる少なく、 良好な成䒈であつたと云ふととを申上げたいのですります。

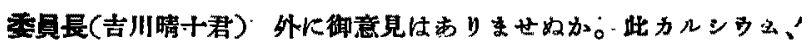

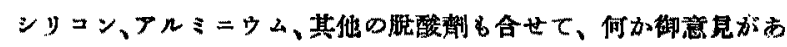
りましたら御逝心を睍ひます。

40 番(演住松二郎君) 甚素鐵を入れますと炭化石灰鉬淬が崩れる

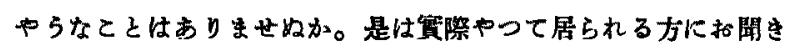

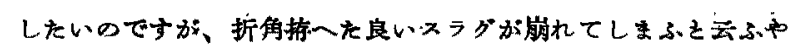
5なととが起りさ5К思はれるのでありますが是はどらでどざい ませ 5 か。

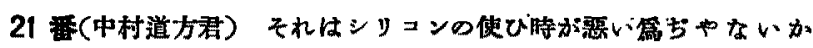
と思ひますが、さら云ふととはどざいませぬか。

40 番(演住松二郎君) 良い使ひ方と官ひますと、それ仕ど5云ふ心凮 に使ふのですか。

21 霜(中村道方君) ぞれは矢張り酸莱が非常に多い場合に使び

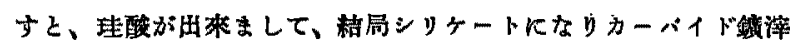

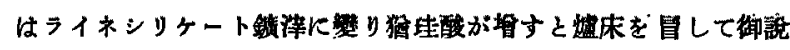

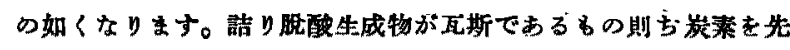

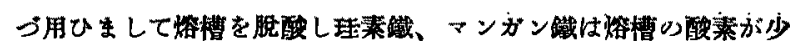
くなつてから初めて便用するのであります。

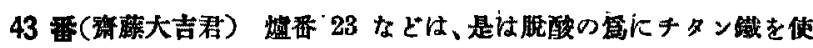

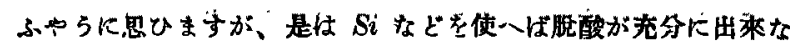
いちら反思ひ主すが。

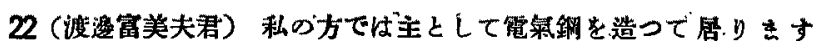
が、此のチタン轱は炭素龬を製造する場合に使つて居ります。划

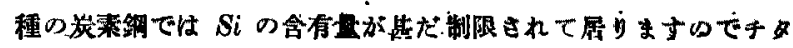




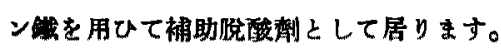

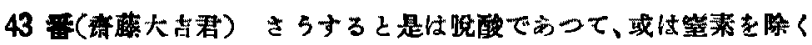
と云ふやらな目的ぢやないのですか。

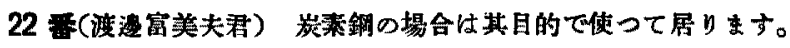

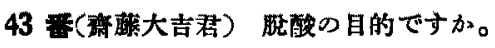

22 番(渡遯富夫碀) さ5です。

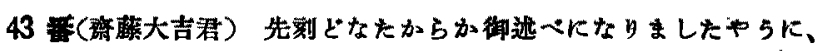
盢度を餘り上げ過ぎるといふと惡くなると云ふととでありました が、其一つの原因は所謂窒素が镸入ると云ふてをではないかと思

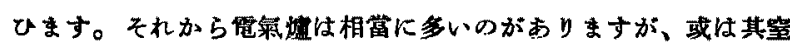
素を除いて軟かくすると云ふやらな目的で御使ひになつて居るか に一寸伺つたをころではさらなつて居りますが、左棣に衔使ひに なつて居つたのであれば司ひたいと思ひ米す。

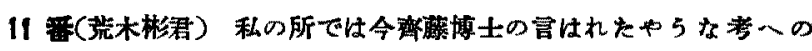

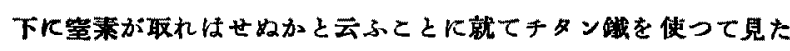
ことがあります。其出來たもの、試䐘の枯果を色々と統計的に取 つて見ましたが、别に是だけ筫が良くなつたと云ふ䊀果が出なか

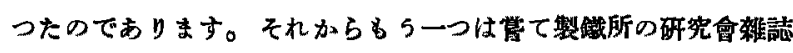

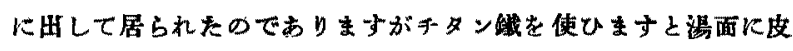
の張りが早いと云ふととでしたが、是る私同じ經驗を得ましたの で、チタン制を使ひますと、ど5も湯の表面に直ぐ皮が張つてし

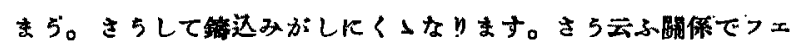
ロチタンを使ふととを止めた䌡驗を持つて居ります。

47 番(溇田長平君) チタン践の問題でありますが私も此間題を 20 何年前から色々研究して何時い榴んで居るのであります。併し嘪

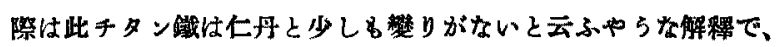
丁货チタン踝は仁丹のやらな感じがするのであります。所が昨年 の秋の名古屋の會でも色ゃフエロチタンのてとに就ても色々議論 がありましたが、此方が良いだら5と思つて、カーボンレスか揚 合に使つたらどらかと思ひす。併しさ5云ふものを集めて一掘 やつて見たいと思つて居ります。カーポンレスのフェロチタンの 場合には业ずやつて行けるるのであると云ふ意見を持つて居るの でありますが是は是非一遍試驗して見たいと思つて居ります。

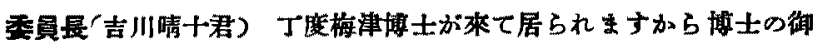
意見を何ひたいと思ひます。

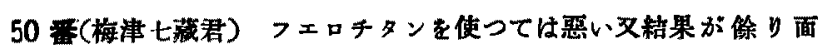
白くないと云ふのは、今浇田さんの仰百いましたや5に、䆵際力 一ボンが可なりあるフェロチタンを御使ひになつたのではないか そ思ひます。それで可成りの炭素を会んで居るフェロチタンを調

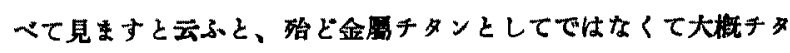

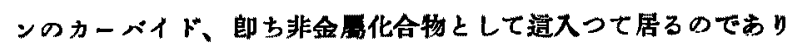

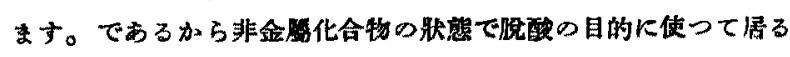
理であるから、從つて教力がないのぢないかと思ひます。是は

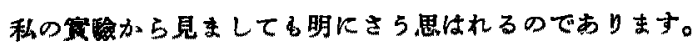

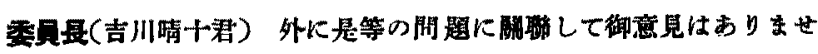
ぬか。

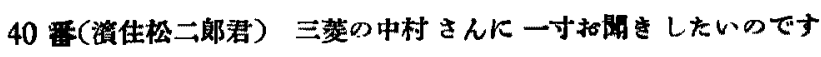

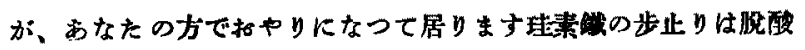
に入れた場合にどの位になつて居りすか。

21 糔(小村道方君) 大能 70 から 80\% Кなつて居ります。

40 番(湍住松二郎涒) き5すると30\%は蠤化するのですか。

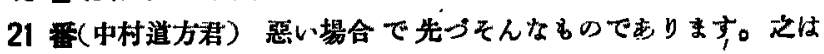

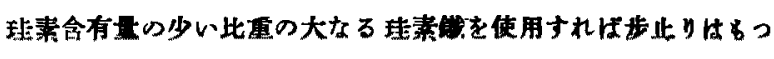
と良くなりますが不蜼は梅西致します。

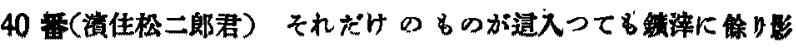
整しないのですか。

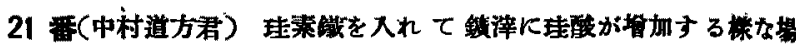
合が起ればそれにマッチするや5にライムを殖やして行くので

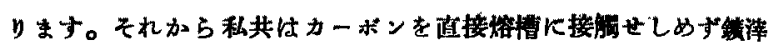
にカルシウムカーパイドを作り此のカーバイドのカーボンを烙橧 の服酸に用ふるといふ事にな日ます。つまり炭菜を石灰の中に一

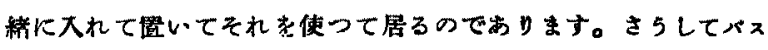

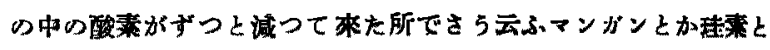

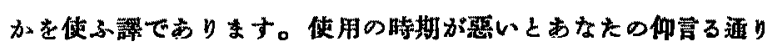

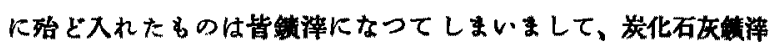
を壤すといふ䊀果になるるる思ひ主。

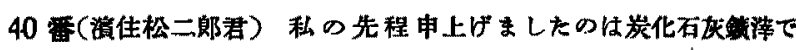

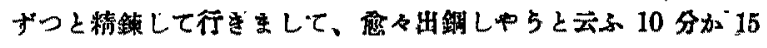

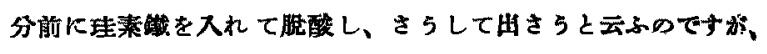
其場合に錪㳯が崩れる倾向がありはしないかと思ふのですが。

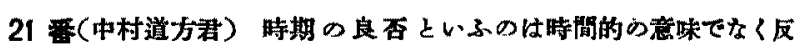

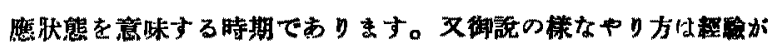
ちりませ好故何とも申上け゚象ねます。

40 番(暂住松三郎君) それで㵊初からずつと分けてスれてやる ఎですか。:

21 番(中村道方君) 最初相當の時閒カーボンでやり其後住芳互に 入れて方す。

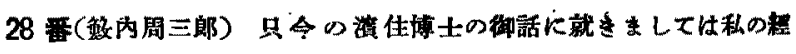

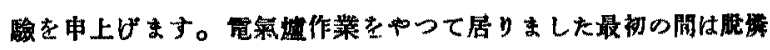

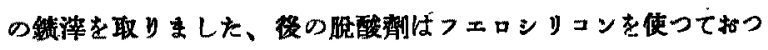
たのですります。それからカーパドスラッグを作つて最後の㧤 酸を行つて出鎆しますとシリコンの步留りが惡らでざいむして、

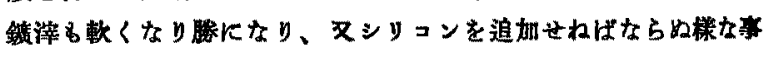

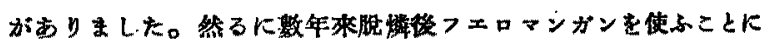

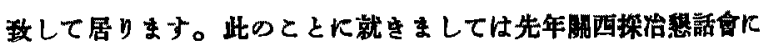

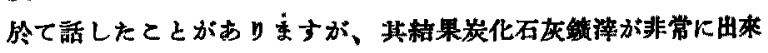

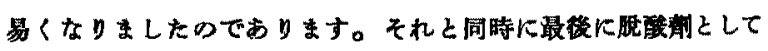
入れますフェロシリコンの步留りは100\%になり制品買る上く

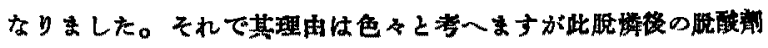

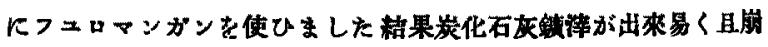

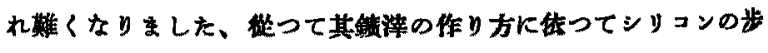
留り中縺㴖の崩れる事に就ては何等心配はないやらです。

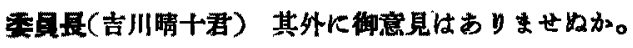

50 梅津七藏君) 低炭素の場合にアルミニゥムを嘘内で眠破の 目的に使ひました坦合に、其脱酸の数力がどの位其入れる前に酸 化して、、惯際の脫酸の教力をなさなかつかと云々、其察際中りま

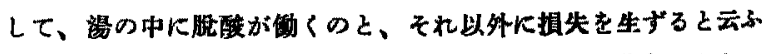
やらなことが分つて居られる方がありますれば一寸御同ひしたい と思Uむす。

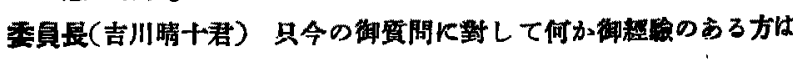
御述一索ひます。

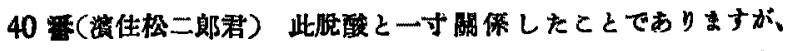
此前の研究部會で吳の榇谷さんがお話された中に第二期に這大つ

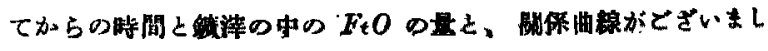


た、それによりましと 30 分位縟つた時が一番 FcO が小いやら

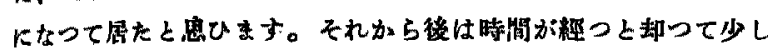

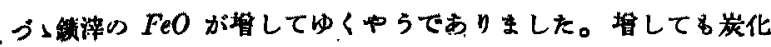
石在籍㴖にはなって店りませ5が、湯心納まりを見ますと、30 分

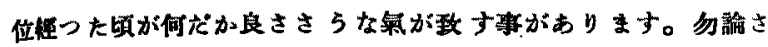
5早く 30 分位で出銅するととはない漛に思はれますが、事宽此 北 $\mathrm{FO}$ が少いるのでせらか。

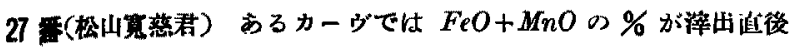

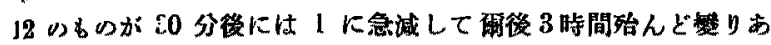

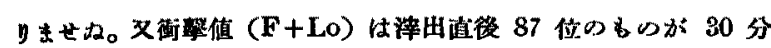

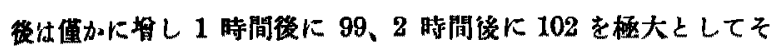

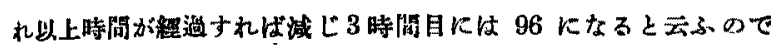

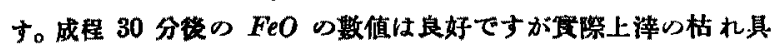

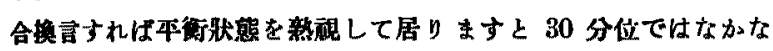

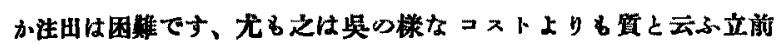

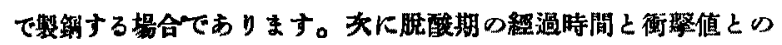

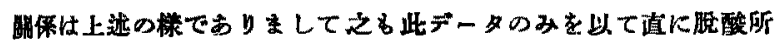
装時間を决定する程度ではないと思ひます。何此間題に就ては目 下研究中であります゚ので他日登表したいと思つて居ります。

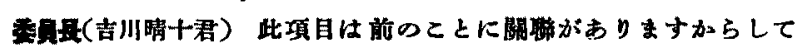

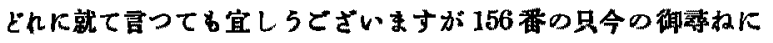
就て御程蹁のある方は御話を頙ひたいと思ひます。

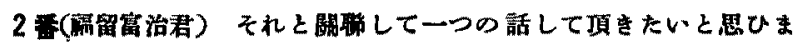
士。

致是昷(吉川晴十君) 检定法は色々あるゃ5ででざいますが特に是 が宜いと思ふ上らなととがございましたならば御話をして頂いた

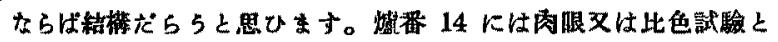
云ふのがありますが、此此色試驗と云ひますと、どう云ふとをで ありますか。之に就て湖話して面きたいと思ひます。

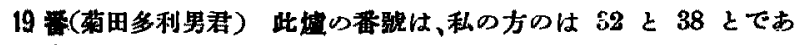
㕫方。

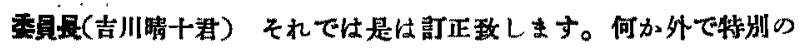
方法をやられて居られるち就でいませ炏か。

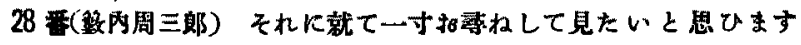

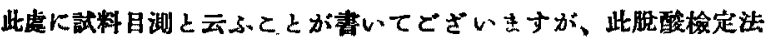

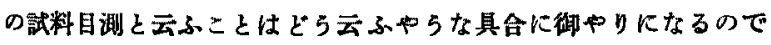
とざいませ5か。失禮でどざいますが御同ひ政します。

25 管(城切政康君) 火花とか、晹の落ちつきの具合と云ふや5な弸 艒を見るのであります。

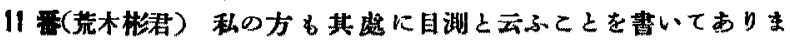

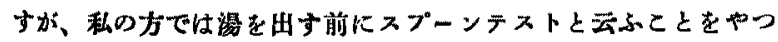
て居ります。サップルを没んで本まして、其表面が固まるまでわ 封間を測つて、出銅温废の湘定の参にして居るのであります。 其時に䂗酸の少い湯は非常に動くのでらります。脽酸のよく出來

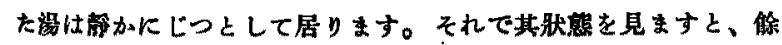
程㧤酸の具合が分るャ5になつて居ります。それからす5一つは 舆方形のサンプルを泩ぎました時に、其表面がふくれたりなんか するのは碰醉が瑟いし、火花心具合加非常に考になります。

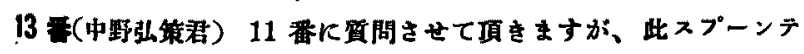

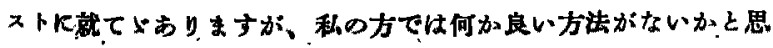
:つて蝶がして居りますのですが、装するに此スプーンテストは非

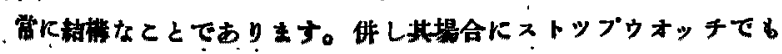

御持ちになつて時間を娜るのでありませらか。

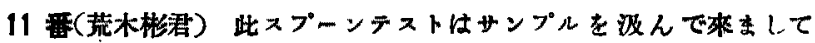
謴の下に植きまして、平らなシャモジのや5なるのでスラッグを

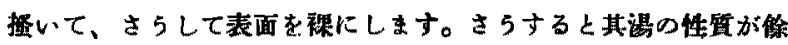
程分る中らに思ふのであります。刎論スプーンテストは唯萑考に すると云ふととだけで、スラッグの状熊と云ふヤらなるの゙タイ ムに非常に關保がすりりすので、其時間だけで、此溫度が高いと、 か低いとか云ふことは炏められませ妨、此位つスラッグのコン ヂションで此位時間があつたならばまあ㥵當なるのであるる云ふ

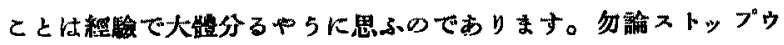
オッチで以て测つて居るのであります。

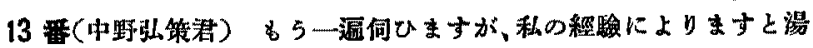
の荒い即古脫酸の利かない時は皮の张り方が運く、治まりの上き 湯は固まり易いのであります、及溫度の低い時も同漛固まり易い のであります。そこで固まる時間のみにより湯の㧤酸程度を判定 することはや小難い橉に思はれるのであります。䊑局䊝てを碩虑 して見掌でやるととになりますが令少し計数的い見分方がないで し中5か。

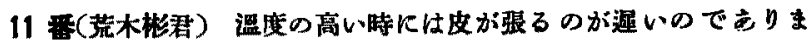

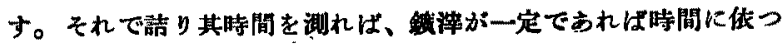
て盢度を示す事が出來ます。

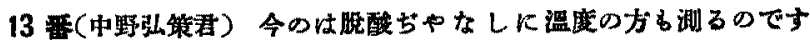
か。

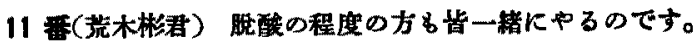

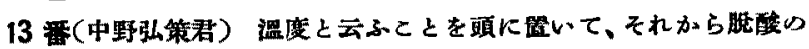
方も一緒にやる、詰り見常でどざいますね。

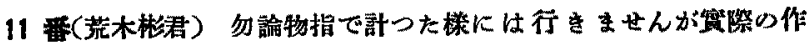
業には此の程度で差支ない程度になります。

13 番(中野弘策君) それは正確に行をますか。

11 悉(荒木涁绉) 可成り正確に行くやらであります。

13 覆(中野弘策君) 私の方では脱酸の方を見たいと思つて居るの

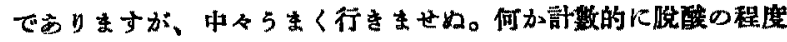
を測定する方法はありませ风でしゃらか。

28 㤦内周三郎君）色心閏かして頂いたのですりますが、私自 身でやつて居ります蔇酸检定の方法を一寸申上げます。是は全部

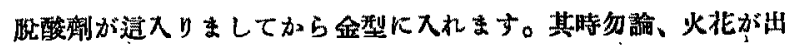
るとかなんとか云ふととはないと思ひますが、それでも概酸の程 度が矢張り分百だららと思ひます。それは金型に固まり来した時

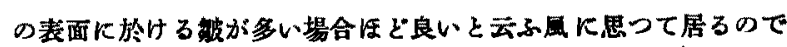

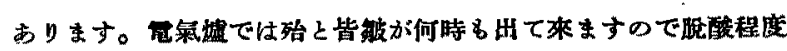
の區別は明瞭でありませんが、酸性平嘘でやりますと脱酸の良い 時、惡い時とははつきり其表面に出来る粮で明䁻に示すゃ5に思 つて居ります。

13 番(中野弘策君) 一寸何ひますが、今の期話で、全部脫酸解を投

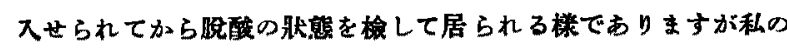

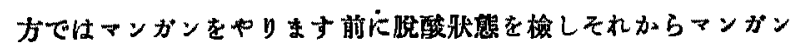
を入れ又脱酸狀熊を見て次にシリコンを投入し最後に更に脫醇を 检して居ります、マンガンをスれる前とマンがンを入れた㷋の脆 酸の具合を見て居られませぬか。

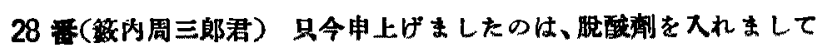

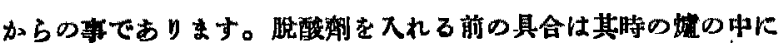

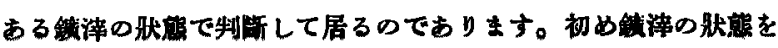


能く見て其の狀態がよければ昜も良いと云ふてとに非得してやっ て居る瀷であります。其霨に點检して居るいであります。

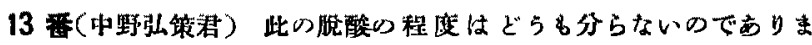
して、それで䊓が分らまく行つて居るかどらかと云ふことを

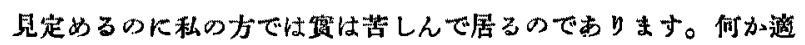

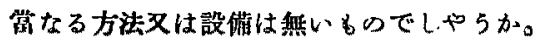

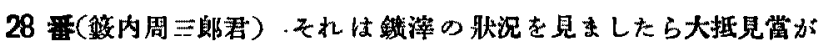
つくことであららと思ひます。

13 番(中野弘策君) それは矢㖘り見常でありますか。

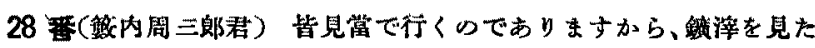
見當で、是位のるのであれば是位の㧤酸制でよから5と云ふやら にしてれて見常でやって居るのであります。

秀貝長(吉川啨十君) 外御意見はありませ如。

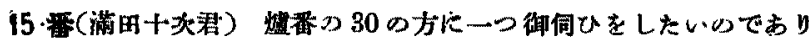
玉すが、脱酸檢定法に㙷擞鏡检定法と云ふカがでざいますが、そ れはどら云ふやらなやり方でやるのですか。一寸御伺ひしたいの です。

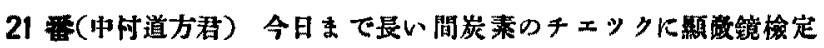

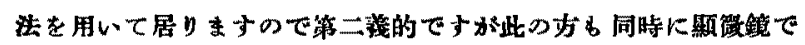
チェックするのです。

15 番(霂田十炊君) そ机は䁌場で御やりになるつですか。

21 番(中村道方君) 現場で試料を取り㨁ぐ其場で野銤政しまして

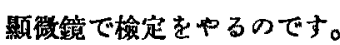

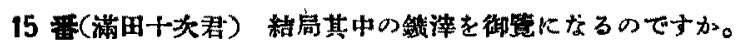

21 番(中村道方君) 其中》炭素含有量を゙ェックすると共にネー チヴスラグ其他色なのるのを㙷德篰で見るのであります。無論

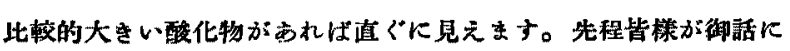

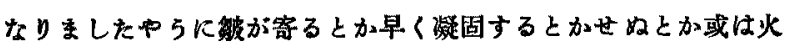

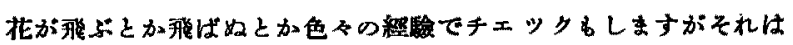
普通の埸合やることでありまして、㫮槏一样儿感ぜられる所でで

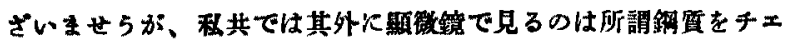

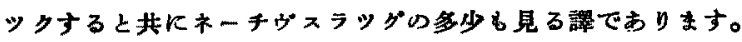

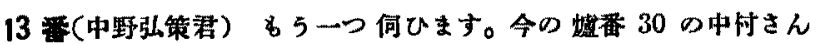

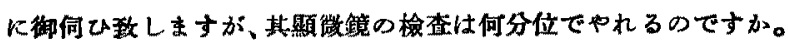

21 番(中村道方君) 5 分位でやつて居ります、そ机で私共はる5

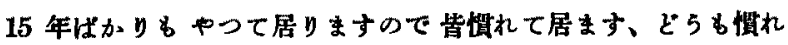
ないとらまくゆかないのでありますが、自然に啃れて来ると思ひ \%。

13 番(中野弘策君) それは大きさにむ依りますけれどる大きさに

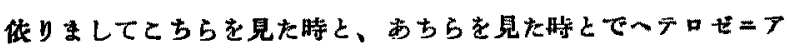
スはありませ奻か。能に私共やつて見ましたが、さ5云ふととが あつて困つたことがあります。

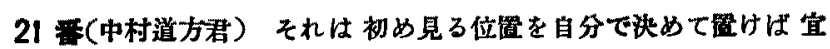
いのです、ちクションを見たり表面を見たりしないで、象に角是 は然練でずつと見つけた面を見て行りば宜いのです。

13 霜(中野弘策君) ど5云ふ風にしてセクションを見られるです s。

21 露（中村道方君）私の方では悇鍊した表面を見て居ります、此等

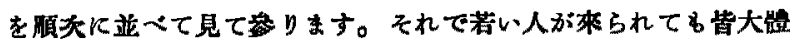
さ5云ふ姴頜でやつて居るのでありますが、别段故障は起らない のであります。それから非賞にむらがあると云はれる場合は均一

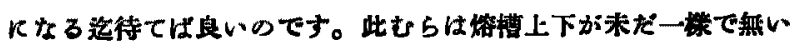

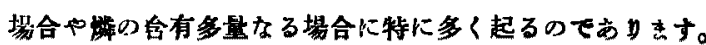

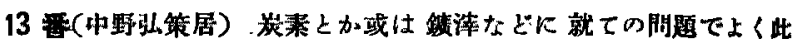
方法を利用しましたが今和共の中上げるつは䂠酸の話ですが、今

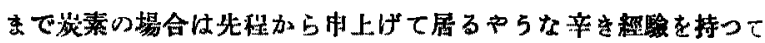
居りますのですが早く決めると云ふととが特に心裂であらうと照 ひます。

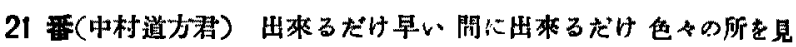

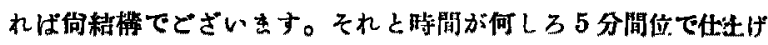

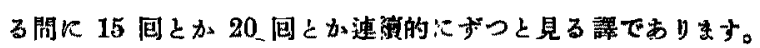

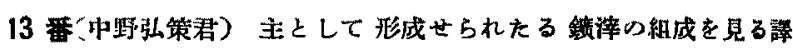
ですか。

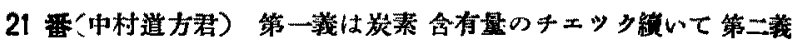
的にネーチヴスラッグの多少を見るのです。唋の酸化物とか概

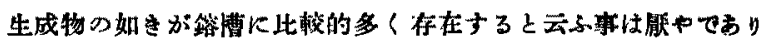

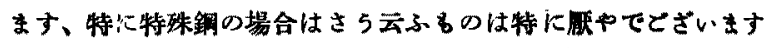
から注意して見る事に致して居ります。

委買長(吉川晴十君) 其外何が御意見はございるせ如か。

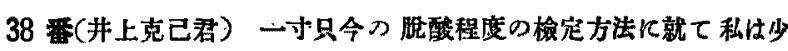

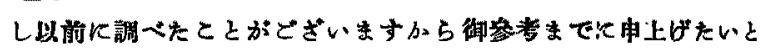
思ひ杂す。方法に少し時間が挂つて面倒ででざいすす讨れをい、

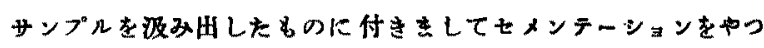
て居るのであります。セメンデーションを政しまして、其表面に

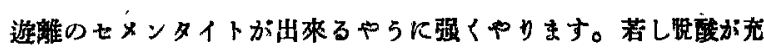

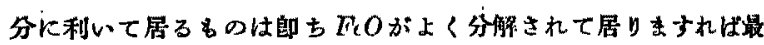
表面に出現するハイパーューテクトイドの居に普通の組織郎ち糊 狀のセメンタイトと屡狀の規則正しいパーライトが出て來ます。 所が璄酸が充分でないとハーライトが切れて粒然を星するとか、 ネットウオークのセメンタイトが崩れるとか获软なつェライトが 現はれて來ると云ふやらなととがございまして、其事唡に就ては

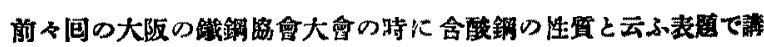

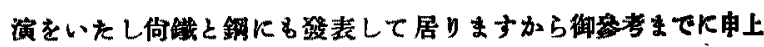
ぼて圈きます。

13 雷(中野弘策君) 今の七メンテーションKよつて鉬中の不能物

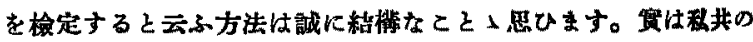
㧘んで居りますことは今湯を出したいと云ふ場合に、今加ら10 分か 30 分後に渴を出したいと云ふ勚合でありますから此をメン

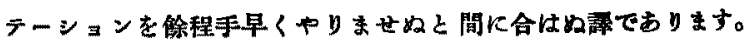

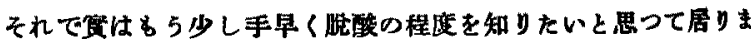
すのですが、何か外に良い方法を敎いて面きたいと思ふのであり ま。

委員長(吉川晴十君) 只今カラビッドブロセスに就て何か御話下さ れば結權だららと思ひますが、外何か御意見はございませる 加。

47 畄(浇田長本君) 色↔の御意見を何ひましたのでありますが、 糸するに銅を精鍊します場合に、高い盢度に熱して硬いるので色 タ吒いてやって行くことす、是は經驗に体るのでありまして、何 彼む初的加物指しでやつて行からと云ふととは私はどら加と

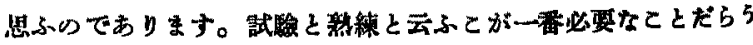
そ思Uます。それで今一寸思つたのでありますが、マンガン、 シリコン、を放り込み生すとしてどの位のマンがン、シリコンを やつたら宜かららと云ふととを、之を定量的にゃりますと、決つ

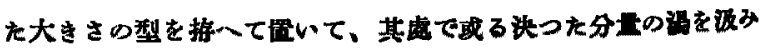


出す。其虎一决まつたダイヤメーダーの針金を突き迈Aで行く。

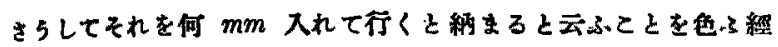
脸で以て造つて見ましてゃりましたならば或る程度に出柬るでら 5と思ふので就ます。私の方でる現場八是等の方法でやら5と したのでありまちが、どらを面倒くさがつてやり生せ收ので、

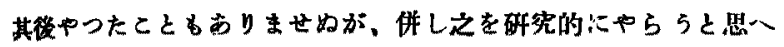

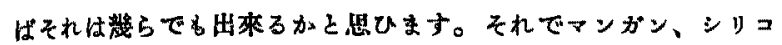

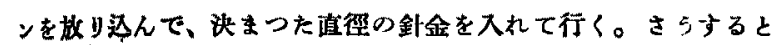

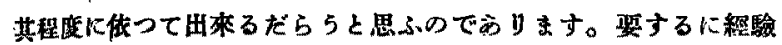
と練とでどラにか或る程度までは出来るだらうと思ひますが、 作し結局付何した所で良い銅を造るに住 10 年位やつた所で充分

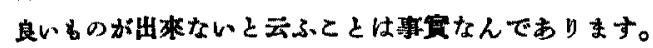

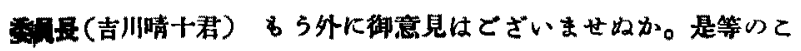

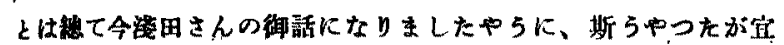
いのだと斯楼に決める㩐に中タいか始と思ひますから、色々と御
意見の交換がありまして、互に利益を得られたてとだららと思

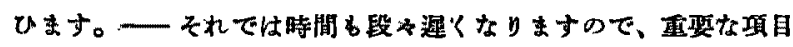

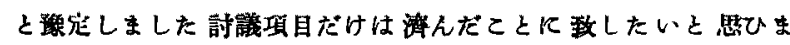

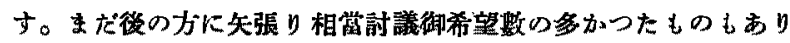

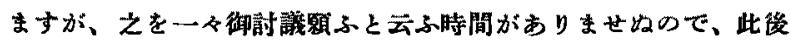
の方は又何時办の機俞に御討竓を願ふとととして、何今まで御討

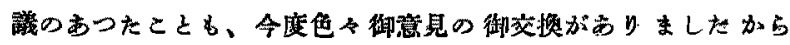
して、文今後の機會に研究されることに政したら結楧だら5と思

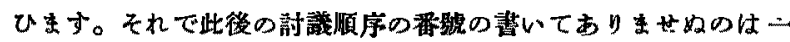
括致しまして、其外つことでむ宜しらでざいますから、何加御意 見のある方は此處に御述べを䝿ひまして、さらして此研究部角を

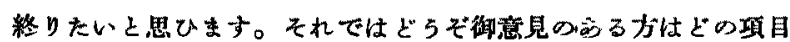

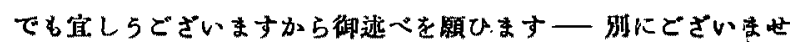

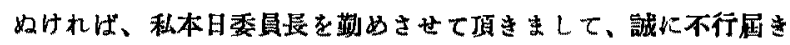
であり去したが、是で御免を願ひたひと思ひまず。(拍手)

\section{IX. 閉 會の挨㑕}

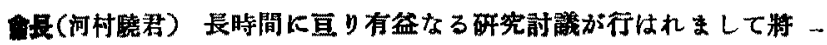

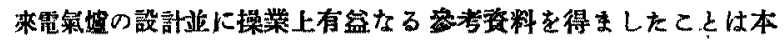
合の欣幸とナる虑でありまして熱心に御畫力下さいました虑の委

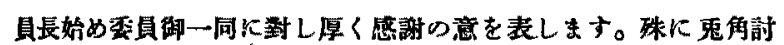

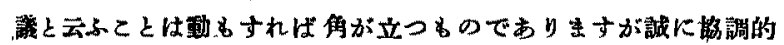

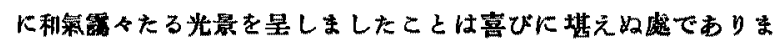

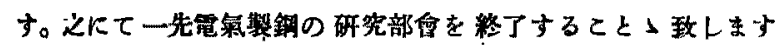

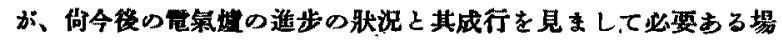
合に更に第 3 回を開くことK赔したいと思ひます、向令年の秋の
太合は满洲で開くととになつて居りますので涩洲側の蔡储委員の

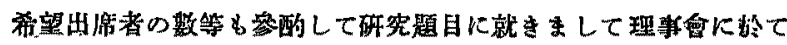

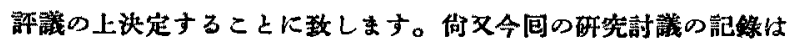
例火侤りまして何れ取縟めて印剧前に御问筧に供し訂正して页く

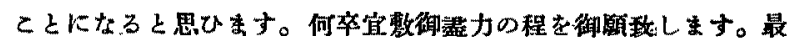

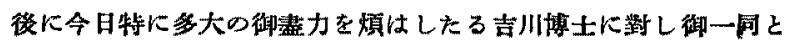
共に拍手を以て感謝の僦を表したいと思ひます。(一同拍手)では 之にて本日の研究部备を閒會致します。（拍手起る）。 